\title{
The Groma and the Gladius: Roman Surveyors in the Later Republic
}

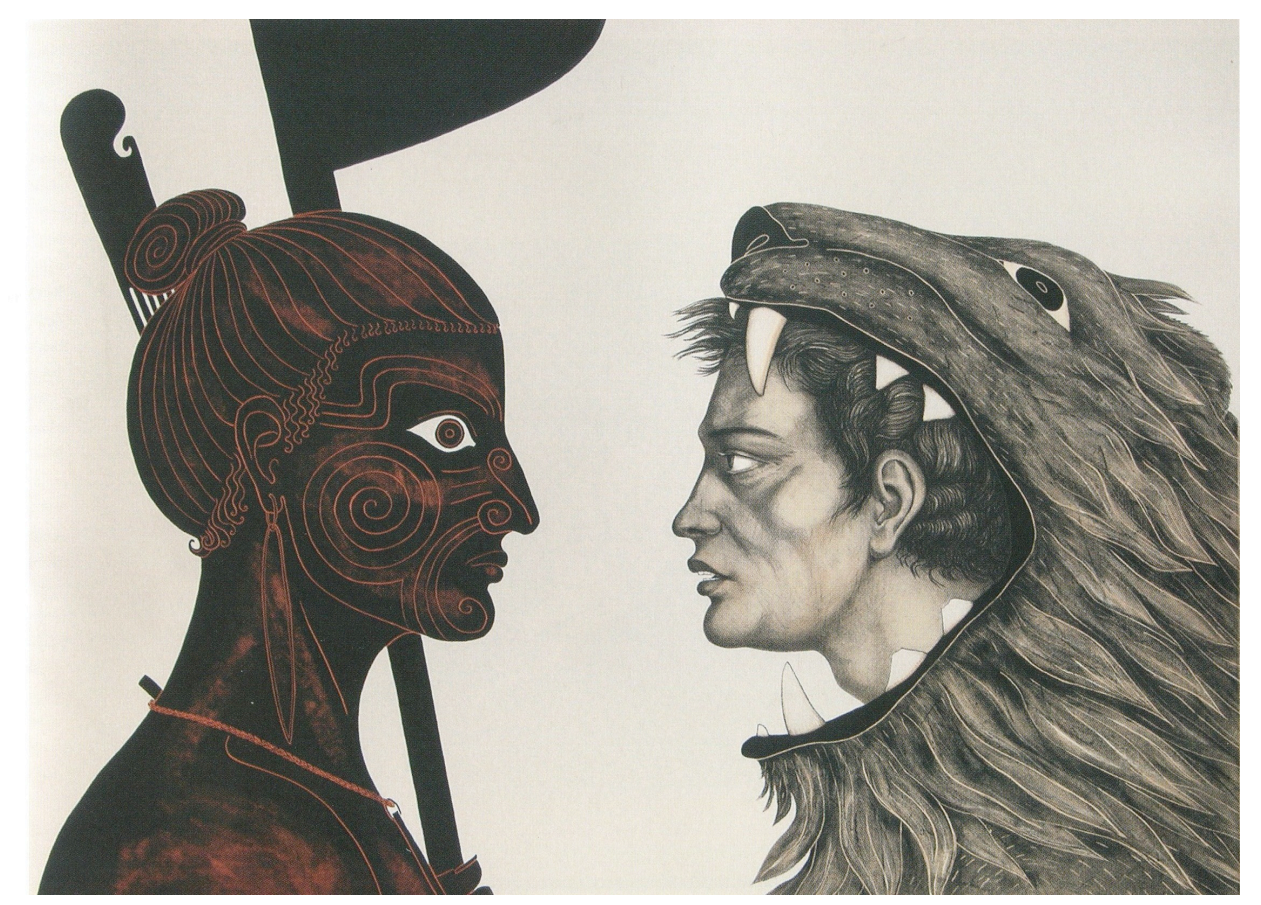

Herakles discusses Boundary Issues with the Neighbours. Reproduced from Maguire 2008, Plate 3.

by

Jason C. Morris

submitted to Victoria University of Wellington in fulfilment of the requirements for the degree of Master of Arts in Classics

Victoria University of Wellington 



\section{TABLE OF CONTENTS}

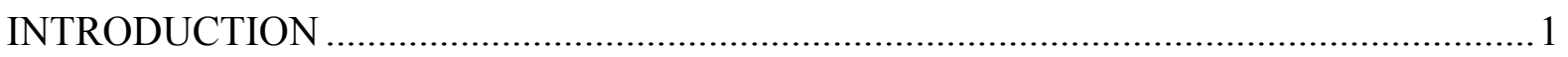

CHAPTER ONE: FINITORES AND THE RITUAL PHILOSOPHY OF BOUNDARIES .....5

CHAPTER TWO: METATORES AND MENSORES: MEN OF MEASUREMENT IN THE

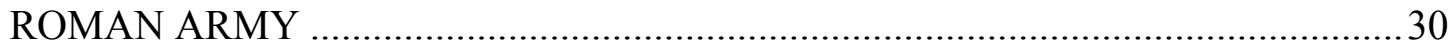

CHAPTER THREE: ROMAN SURVEYORS FROM SULLA TO CAESAR …...................64

CONCLUSION

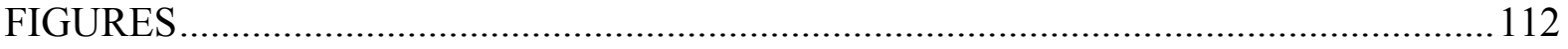

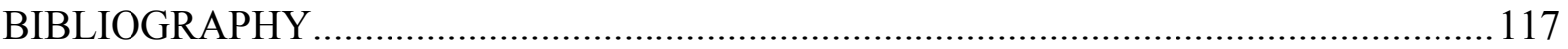




\section{ACKNOWLEDGEMENTS}

In writing this thesis I have received an incalculable amount of assistance and support from a number of people. It seems only fitting that I acknowledge their contributions to the final product here.

First, I need to thank Marty Davis of the Royal New Zealand Foundation of the Blind, who obtained an Oppenheim grant that enabled me to pay my academic support workers. Next, I would like to thank Hannah Webling who so kindly helped prepare the figures for my thesis. Thirdly, I need to acknowledge a real debt to James McNamara who generously spent several hours working through texts in German with me when my own limited knowledge of that language proved utterly inadequate. Next, many thanks to Dan Diggins and Alex Wilson for their technical assistance. Many thanks also to Mark Masterson for hours of discussion on the poetry of Statius. Likewise, many thanks to Judy Deuling for guidance on all things Etruscan. I give endless thanks to my advisers Matthew Trundle and Arthur Pomeroy who both guided my research and digested the text as quickly as I wrote it. Your comments saved me from enumerable errors. Finally, my deepest debt of gratitude must go to Tania Hayes, who as my academic assistant devoted more time and suffering to this project than anyone else. Tania, thank you so much for all your hard work. Without your efforts this thesis would not be what it is. 


\section{INTRODUCTION}

They are indeed surveying the land at Veii and Capena; this is not far from my Tusculan estate. However, I am not at all frightened. I will enjoy this as long as possible and hope that this will be forever. If it does not turn out so, then, since as befits a brave hero and also a philosopher, I have decided that staying alive is the finest of things, I cannot help but thank the fellow by whose kindness I have gained that result. ${ }^{1}$

Lucius Soranus son of Lucius, Lucius Arrius son of Marcus Praetorial Quattuorviri, saw to it that a boundary was established in accord with the Senate's decree. $^{2}$

Boundaries have been a concern for all settled peoples in all times and places. The Romans were no exception to this rule. Literary documents from the second century B.C. right through to the end of the Western Empire in the fifth century A.D. show a continuous preoccupation with the delineation of boundaries and the ownership or control of land. ${ }^{3}$ As part of this preoccupation, the Romans developed a complex legal framework for coping with property ownership. To accompany this legal framework, they developed a sophisticated system of boundary marking and land surveying known as centuriation. A great deal of scholarly attention has been expended on understanding both the system of centuriation and the legal framework governing Roman land use. ${ }^{4}$ Far less attention has been paid to the social development of the agrimensores or land surveyors who actually carried out the operation of centuriation and dealt with the problems of property disputes in the Imperial period. ${ }^{5}$ This thesis will focus on the social identity of the Roman land surveyors with a particular emphasis on understanding their origins in the surveying institutions of the later Republic.

To accomplish this study, the thesis will be broken down into three broad chapters, each chapter containing two or three subsections. The first chapter will examine the social identity and evolution of the finitor, who has traditionally been considered the surveyor of the Roman

\footnotetext{
${ }^{1}$ Veientem quidem agrum et Capenatem metiuntur; hoc non longe abest a Tusculano; nihil tamen timeo. Fruor dum licet, opto ut semper liceat; si id minus contigerit, tamen quoniam ego vir fortis idemque philosophus vivere pulcherrimum duxi, non possum eum non diligere, cuius beneficio id consecutus sum. (Cic. Ad Fam. 9.17.2).

${ }^{2}$ L(ucius) Sora(nus) L(ucii) F(ilius) / L(ucius) Arrius M(arci) F(ilius) / IIII uir(i) Pr(aetores) D(e) S(enatu) S(ententia) / term(inandum) c(urauere). (CIL 12.1574).

${ }^{3}$ For examples see: Plaut. Poen. 45-49; Cass. Var. 3.52.3-8.

${ }^{4}$ For further reading, consult: Dilke 1971; Gargola 1995; Campbell 2000; and Weber 2008.

${ }^{5}$ For a recent exception to this trend, see: Cuomo 2007, 103-130.
} 
Republic. The second chapter will examine the identity of the agrimensores or mensores in the particular context of the Roman army in an effort to distinguish them from the metatores, three names which have been considered to refer to the same or a similar occupation. The third chapter will examine the mensor in the context of the Roman Republic and trace the social forces that shaped their identity as specialists in land law and surveying.

The sources for such a study cover a bewildering array of materials from Latin poetry to archaeological remains. Each type of evidence carries its own bias and set of problems. The limit on space imposed by the nature of this thesis means that not all aspects of such problems can be examined in every case. However, I have, where possible, noted and addressed issues of authorship, intended audience, provenance, and bias that may directly impact this study. In keeping with this principle, I have adopted a multi-faceted approach to research and analysis. In Chapters One and Two I draw heavily on a close philological study of select words and their meanings combined with a close synthetic reading of texts and inscriptions. ${ }^{6}$ In some cases, I supplement this synthetic reading with archaeological evidence that reinforces or demonstrates a specific point. In Chapter Three I use a synthetic and analytical approach in order to integrate the evidence from ancient texts with archaeological evidence in a narrative framework. To prepare the groundwork for such a study, it is necessary to briefly sketch the nature of Roman surveying and its use and to define some terms which the reader will encounter in the text (and which would be tedious to explain in the course of the discussion).

Until recently, it has been held by modern scholars that the Roman system of land surveying developed as a fusion of Greek and Etruscan concepts which were employed to organize Roman military coloniae beginning in the mid fifth century B.C. ${ }^{7}$ In this reconstruction, the earliest land divisions formed irregular field systems delineated by balks or ditches which were referred to as striga if they were longer than they were broad, and scamna if they were broader than they were long. ${ }^{8}$ The act of creating these field systems was known as strigation and scamnation. From this system of balks and ditches, the Romans developed the system of interlocking squares known as centuriation. In centuriation, squares of 120 by 120 Roman

\footnotetext{
${ }^{6}$ Many of the texts used in this study are drawn from the sixth century collection known as the Corpus Scriptorum Agrimensorum. Passages selected from this work are cited using the page and line numbers from Campbell 2000.

${ }^{7}$ See: Dilke 1971, 19-41; Gargola 1995, 37-42.

${ }^{8}$ Gargola 1995, 39-40; Campbell 1996, 85-86.
} 
feet formed a basic unit known as an actus. 8 actus formed a iugerum and 200 iugera formed 1 centuria, from which term the system takes the English name of centuriation. ${ }^{9}$ While there can be little doubt that this system was in place by the end of the third century B.C., recent reassessments of archaeological evidence from Italy have challenged its existence in the period before the Second Punic War. ${ }^{10}$ Until this reassessment can be verified or refuted by further archaeological investigation, it will not be possible to establish a new paradigm for the development of Roman surveying practice and systems of land tenure in the early or middle Republic. All that can be said is that centuriation developed during the third century alongside another related, nonetheless, different system of surveying known as castramentation.

Castramentation was the use of interlocking squares and lines to form the Roman castra or fortified field camp. ${ }^{11}$ Like centuriation, castramentation was intended to delineate space and create an artificial area of control within the natural landscape. However, unlike centuriation, castramentation operated on a small scale and created an entirely artificial quadrilateral space enclosed by a man-made bank and ditch. Centuriation, on the other hand, could cover several square kilometres, rarely incorporated wall fortifications, and often involved irregular features such as roads and rivers.

Since the development of castramentation, the castra, and those responsible for its construction will be discussed in Chapters Two and Three, little more need be said about it here. However, the coloniae that formed the backdrop of much centuriation deserve a few remarks, as I will not discuss them prominently in the following discussion. As the Latin term colonia suggests, this institution was an agricultural community established by the Romans for the purpose of controlling newly conquered land. ${ }^{12}$ Under the Republic, the Roman people inaugurated each colonia with a lex or law authorizing a board of three senatorial exmagistrates to lead out and establish a group of colonists on the land. The board of three was known as the triumviri. ${ }^{13}$ Supplementing these triumviri there were boards of ten or decemviri, who were charged with establishing individual allotments of land to Roman

\footnotetext{
${ }^{9}$ See: Front De Lim. 10.16-20; Gargola 1995, 39-41; Campbell 1996, 83-84.

${ }^{10}$ See the discussion in: Pelgrom 2008, 333-372.

${ }^{11}$ For some discussions of castramentation, see: Hanel 2007, 402-408; and Dobson 2008, 68-72.

${ }^{12}$ For the most recent discussion of this institution, see: Braudhead 2007, 148-161.

${ }^{13}$ On the triumviri and colonial laws, see fundamentally: Gargola 1995, 25-31 \& 52-63; and discussed more recently by Braudhead 2007 in the course of his article cited above.
} 
settlers outside the context of the colonia. ${ }^{14}$ The exact nature and identity of those who actually carried out the work of surveying under the direction of the triumviri and decemviri will be considered in Chapters One and Three. In the first century B.C. at least, the individual members of these boards were known as deductores. ${ }^{15}$ Each settlement project, whether in individual allotments known as viritane assignments or a colonia, had its own separate board or commission until the time of the tribunate of Tiberius Gracchus. ${ }^{16}$ Tiberius and later his brother Gaius seem to have established a practice by which a single board could establish multiple coloniae. ${ }^{17}$ The chaotic events of the first century B.C. and the constant contention over the settlement of Roman military veterans in new or existing coloniae by successive Roman generals further transformed Republican surveying institutions. By the time of Caesar, the system had transformed to the point where a single deductor and one or more surveyors established a colonia. ${ }^{18}$ Under the Empire, this single deductor became known as a conditor and their surveyor, the mensor or agrimensor. ${ }^{19}$ The mensor and related occupations will be explored, particularly in the context of the Roman army, in Chapter Two. To complete this study, the gradual evolution from the triumviri and the surveying institutions at the end of the second century B.C. to the rise of the mensor or professional surveyor in the dictatorship of Caesar will form the main subject of Chapter Three.

\footnotetext{
${ }^{14}$ See: Gargola 1995, 103-113; and Campbell 2000, 472-474.

${ }^{15}$ See: TLL 5.283-284.

${ }^{16}$ Gargola 1995, 58-63, \&106-107.

${ }^{17}$ For the best discussion of the Gracchi and their land legislation, see: Gargola 1995, 148-174; Mouritsen 2008, 471-483; and Rich 2008, 543-572. Modern scholars have placed great emphasis on the activities of the Gracchi, and most of the articles in the volume edited by De Ligt and Northwood touch on their activities or the impact of their laws. Anyone seriously interested either in land-law, the Gracchi themselves, or in the social history of the Late Republic would do well to consult the volume as a whole since the bibliography associated with the individual articles are superb.

${ }^{18}$ For surveying in the age of Caesar, see: Keppie 1983.

${ }^{19}$ For the conditor, see: Var RR 3.1.6; Virg. Aen 8.313; and TLL 4.146-147. For mensor see: TLL 8.753-754. For Agrimensor, see: TLL 1.1428. A mensor was anyone who measured and an agrimensor was someone who specifically measured land for most of Roman history. However, by the end of the Roman Empire, the two words seem to have been treated as interchangable. See: Veg. Mil. 2.7.9 \& 3.8.4.
} 


\title{
CHAPTER ONE FINITORES AND THE RITUAL PHILOSOPHY OF BOUNDARIES
}

\begin{abstract}
Now I wish once again to return to the plot so that you will know as much as I. I will presently establish the regions, the limits, and the boundaries of this play: I have been appointed as a divider (finitor) for the task. ${ }^{1}$

Those who we now call land surveyors (agrimensores) were once called dividers (finitores): they were so called because they divided up land. Plautus in the Poenulus [48-9]: "presently I will establish the regions, the limits, and the boundaries of this play; I have been appointed as a divider (finitor) for the task."2
\end{abstract}

These two quotations by the playwright Plautus and the grammarian Nonius Marcellus have been used by scholars to show that the Latin terms agrimensor or mensor and finitor referred to one and the same occupation at different periods in Roman history. However, the two most recent examinations of the finitores have tentatively suggested that the two words did not in fact mean the same thing, and that the finitores may not have been professional surveyors, but rather religious officials appointed by the augurs for the purpose of establishing the limites confiniaque coloniarum. ${ }^{3}$ While both of these studies have their persuasive elements, neither makes a full study of the uses of the word finitor and its changes through history. As a consequence, they are far more successful at stating what the finitores were not rather than what they might have been. In this chapter we will consider the different uses of finitor and, through a close study of the texts, establish what finitor meant to the Romans of different periods. This will enable us to better conceptualize the finitores' role in Roman Republican culture and the conceptual or philosophic changes that social identification went through under the Empire. For the sake of clarity in translation, the term finitor will here be translated as 'divider' or a 'boundary' and the term agrimensor or mensor will be translated as 'land surveyor'.

\footnotetext{
${ }^{1}$ Ad argumentum nunc vicissatim volo/ remigrare, ut aeque mecum sitis gnarures/. Eius nunc regiones, limites, confinia/ determinabo: ei rei ego finitor factus sum. (Plaut. Poen. 46-49).

${ }^{2}$ Finitores dicebantur, quos nunc agrimensores dicimus: dicti quod finis dividerent. Plautus Poenulo [48-9] “eius nunc regiones, limites, confinia determinabo: ei rei ego finitor factus sum.” (Non. De Prop. Serm. 1.15. My text is that of the 1895 Oxford edition.)

${ }^{3}$ Classen 1994, 161-70; Gargola 1995, 91-92, 183-185, 205, 221-222, 249-250. Also by way of contrast, see: the earlier study in Nicolet 1970, 72-103.
} 
The texts mentioning finitores can be divided into three main groups. The first group, from the Roman Republican period, is represented by a reference in the Poenulus of Plautus and by references in Cicero's second speech against the Rullan land law of 63 B.C. The second group, from the early imperial period, is represented by passages from Seneca's Natural Questions, a passing reference in Lucan's Civil War, a single reference in the Sixth Satire of Persius, and a reference in the Thebaid of Statius. The third group, from Late Antiquity, is represented by the reference made by Nonius Marcellus and by passages in the works of Martianus Capella. We will begin our investigation with the second group of texts because it is the largest sample and because it forms a strong bridge between the oft-quoted Republican literature and that of Late Antiquity, thus providing a context for the examination of both the earlier and later texts.

\section{THE IMPERIAL TEXTS}

Of all the authors listed from the imperial period, Seneca is, without argument, the most influential. As tutor to the emperor Nero, he held a prominent place in the Roman government. Indeed, it might be argued that his only political rivals in the early years of Nero's reign were Burrus, the Praefectus Praetorii, and Agrippina, Nero's mother. ${ }^{4}$ In addition, he was a Stoic philosopher who, as Brad Inwood put it, did not simply parrot the intellectual and philosophical ideas of his day. He contributed original concepts to the dialogue, and, moreover, doing so in Latin, not in Greek. ${ }^{5}$ Such a use of Latin for advanced philosophical dialogue sets Seneca and his peers apart from other Roman intellectuals, causing scholars such as Inwood to note the unique intellectual environment of the ClaudioNeronian age. ${ }^{6}$ Seneca's position and educational milieu meant that he was a man who stood out in the literary and intellectual circles of the day and was well placed to influence other authors and thinkers. This is particularly important for the work of Lucan and Persius, both of whom came to prominence at Nero's court during Seneca's primacy. ${ }^{7}$ For this reason, we will

\footnotetext{
${ }^{4}$ Griffin 1992, 39-47; Griffin 2000, 69-74; Conte 1999, 408-10.

${ }^{5}$ Inwood 2005, 3-5, 13-21.

${ }^{6}$ Inwood 2005, 12-14.

${ }^{7}$ Griffin, 2000, 70; Conte 1999, 440-442, 467-8. It is interesting that the influence of Seneca seems to have come to Persius predominantly through his friend Lucan since, according to the Vita Aulis Persii Flacci, he did
} 
examine the use of finitor in the Natural Questions first, not because that work was written before the works of Lucan or Persius, but because the thoughts of the man who wrote it almost certainly found their way into their minds.

Seneca's Natural Questions is often considered a dry encyclopedic work filled with obscure philosophic concepts. On closer inspection though, it turns out to be a complex and at times even fascinating study written as part of a long tradition of discourse about the nature of human beings' relationship to God through an investigation of natural phenomena. ${ }^{8}$ The examination of this relationship and its philosophical tradition are quite evident in the discussion of the winds in Book Five where Seneca makes use of the term finitor. The use of a term which, as was noted in the introduction, tends to be connected with surveying here seems at first sight both inexplicable and confusing, though close examination of the text in context makes it less so.

However, it is agreed that there are twelve winds, not because such a number is ubiquitous (indeed it is the tendency of the world to exclude some), but because nowhere are there more. Thus we state that there are six cases, not because each of the six names is accepted, but because there aren't more than six.

Those who stated that there are twelve winds supported this by stating that the total number of winds were equal to the divisions of the sky. However, the sky is divided into five zones, which pass along the axis of the world. There is the Northern, the solstice, the Equinoctial, the winter, and the Southern. To these a sixth division is added which separates the upper part of the world from the lower; for as you know, the upper hemisphere is always separated from the lower.

This line, which is between the visible and hidden regions, is the zone the Greeks call the horizon, but our people call either the boundary-marker (finitor) or the boundary line (finiens). ${ }^{9}$

\footnotetext{
not meet Seneca until late in his life. See: Vit. Pers. 5.2. This view is in many ways supported by Housman's assessment of the astrological sections of Lucan's writing. See: Luc. BC 9.490-497, 10.199-218; Sen. QN 3.22.1, 5.17.1-5.18.15; and Housman 1926, 334-337.

${ }^{8}$ Inwood 2005, 157-161.

${ }^{9}$ Placet autem duodecim uentos esse, non quia ubique tot sunt (quosdam enim inclinationem terrarum excludit), sed quia plures nusquam sunt. Sic casus sex dicimus, non quia omne nomen recipit, sed quia nullum plures quam sex. Qui duodecim uentos esse dixerunt, hoc secuti sunt, totidem uentorum esse quot caeli discrimina. Caelum autem diuiditur circulos quinque, qui per mundi cardines eunt: est septemptrionalis, est solstitialis, est aequinoctialis, est brumalis, est contraries septemtrionali. His sextus accedit, qui superiorem mundi ab inferiore secernit (ut scis enim, dimidia pars mundi semper supra, dimidia infra est): hanc lineam, qui inter aperta et occulta est, id hunc est circulum Graeci G-horizonta uocant, nostri finitorem esse dixerunt, alii finientem. (Sen. QN 5.17.1-3). The general association of winds, wind direction, astronomy, and the understanding of either time or space can be documented from sundials and texts on meteorology and cosmology. For discussions of these subjects, consult Schaldach 1998; Hannah 2005, 122-31; and Lehoux 2007 , 208-9.
} 
Seneca goes on to discuss the zone of the Meridian, the division of the world into fifths, tenths and quarters, after which he discusses the origin of the winds and their benefits to mankind, and finally ends on a sombre note by considering whether or not the world would be better off without the winds. ${ }^{10}$ This last seems to be a conflicted reflection on the Roman Empire and the nature of imperialism. This ambivalent reflection on Roman imperialism is an important element in understanding Seneca's use of finitor, and for the understanding of the term in the consciousness of the other imperial authors.

For Seneca, the understanding of finitor seems to have been transferred from an individual and occupation to an intangible philosophical concept with strong moral connotations. $\mathrm{He}$ remarks "They asserted that it was a boundary separating us from the Other", a statement which indicates that, to philosophers of Seneca's day, the G-horizonta was, in the minds of Greeks from a bygone era, equated to the function of the Equatorial region, which philosophers from the second century $\mathrm{BC}$ onward regarded as an impassable boundary between the oikoumene, or inhabited world, and the other hemisphere of the earth. ${ }^{11}$ This concept was rooted in the astronomic and geographic work of Eratosthenes of Cyrene, which was for Stoics a part of the geographically oriented moral philosophy articulated by men such as Crates of Melos and Posidonius. ${ }^{12}$

The use of finitor in such geographically oriented philosophy indicates that to Seneca it was a boundary which could not or at the least should not lightly be crossed. At the same time, the transient nature of the horizon suggests that it was also a highly subjective boundary set down by individuals which could be adjusted or moved in accordance with a given individual's perception of time and space. Since Roman perceptions of time and space are only just beginning to be fully understood by modern scholars, it is difficult to say how they may have affected their total appreciation of such concepts. ${ }^{13}$ Even so, it seems not unreasonable to conjecture that the Roman understanding of time and space underwent subtle changes and refinements in the century between Caesar's introduction of the Julian calendar in 46 B.C.

\footnotetext{
${ }^{10}$ Sen. $Q N$ 5.18.4-14. Also see: Sen. $Q N$ 5.14.2, 5.16.1-5, and the discussion of $Q N 5.18$ in Romm 1992, 165167 ; and Inwood 2005, 178.

${ }^{11}$ Romm 1992, 154; Geus 2004, 14.

${ }^{12}$ For expanded discussion of this philosophy, see: Nicolet 1991, 61-67; Clarke 1999, 239-248, \& 282-293; Jones 2003, 328-342; and Geus 2004, 12-24.

${ }^{13}$ For some thoughts on the reconstruction of time and temporal perceptions, see: Feeney 2007, 7-16; Hannah 2009. For a discussion on the reconstruction of Roman spatial understanding, see: the lengthy account in Clarke 1999, 7-76, supplemented by discussions of maps and plans in Talbert 2008, 12-28; and Trimble 2008, 67-69, 94-97.
} 
and the early writings of Seneca in the end of the reign of Claudius. Furthermore, there are hints in various literary documents and in the inscriptions on sundials which suggest that those refinements may have involved a heightened appreciation amongst at least the intelligentsia for the philosophical principle of relative time. ${ }^{14}$ This is to say that they were beginning to appreciate that one's perception of time was dependent on one's location within the oikoumene and that perceived differences in the passage of time, as expressed by the movements of the stars, could in turn be used to express ideas about location. Such principles in a more complex context might have also been used to establish imaginary temporal or spatial lines of demarcation, which could have served a variety of philosophical, political, and religious functions. It is not possible to trace the course of such a socio-philosophical trend within the context of this study or even to prove that it took place. However, it is worth keeping the possibility of such a development in mind as it may help explain the changes in the use of the word finitor which have already been noted and which will be considered more fully below. It is also worth remembering when considering some of the roles of astronomical phenomena and boundaries in the works of authors such as Lucan and Statius.

Lucan invoked the term finitor as part of a highly metaphorical description of Cato's march through the desert during his conflict with Caesar in the civil war. The word finitor occurs in a description of the army's departure and helps to establish the hopelessness felt in trying to navigate through an empty landscape where the only guidance comes from the stars.

Now the whole journey lies ahead and there are no landmarks [unless they be the celestial flames as in the midst of the plain]. They recognize their path by the constellations. But the horizon that bounds the Libyan shore does not display all the constellations, but hides many in the descending margin of the lands. ${ }^{15}$

The use of constellations, particularly the Big and Little Bears, to guide an army on the march was a common theme in military literature and martial epic, both prose and verse. ${ }^{16}$

\footnotetext{
${ }^{14}$ For some preliminary indications of this philosophical trend see: App. BC 2.21; Dio 43.26; Str. Geog. 1.1.21, 2.3.1, 2.5.10, 2.5.34; Vitr. Arch. 1.6.6, 1.6.12, 9.1.1, 9.1.4, 9.7.1-3; Plin. NH 18.211-212, 18.246-9; Suet. Aug. 8, 31; Censor. DN 20.8-12; Macr. Sat. 1.14.5-15; Sen. QN 5.17.1-5; Luc. BC 9.490-497, 10.199-221 and the evidence of the Horologium Augusti along with portable sundials in general. For indirectly relevant remarks, see: Talbert 2008, 25-28, and Hannah 2005, 118-122 \& 126-134. For the original archaeological publications on the Horologium Augusti, see: Buchner 1993-1994, 77-84.

${ }^{15}$ Iamque iter omne latet nec sunt discrimina terrae:/ [ulla nisi aetheriae medio uelut aequore flammae] /sideribus nouere uiam; nec sidera tota /ostendit Libycae finitor circulus orae, multaque deuexo terrarium margine celat. (Luc. BC 9.493-497). For a full commentary on these lines, see: Wik 2004.

${ }^{16}$ Polyb. 9.14.2-9.15.5; Veg. Mil. 3.6.9-12, 3.26.27; Str. Geog. 17.1.45; Diod. Sic. 2.54.2; Curt. 7.4.28, 7.5.5; Arr. Anab. 3.3.4, 6.23.1; Plin. NH 5.26, 6.166.
} 
However, the language Lucan selected to evoke the image of soldiers blinded by the dust kicked up by marching feet so that they could not discern the landscape and were forced to navigate by the stars seems very unusual, if not unique. Parallels for individual word groups and even parts of whole lines seem to appear in other epics and some select prose texts, but the closest direct parallels to the entire passage come from works by Seneca and Martianus Capella on meteorology, astronomy, and cosmology. ${ }^{17}$ This suggests that Lucan was not just bowing to the vicissitudes of metre and epic convention, but was attempting to convey a complex philosophical concept, which was bound up with his own worldview and the larger themes of his epic.

If one reads the Bellum Civile through the lens of Seneca's philosophic writings, Lucan's own philosophical attitude seems far more pragmatic than most modern scholars make it out to be. For most scholars, Lucan was a hard-line Republican with an interest in seeing the Senate restored to its old place of prominence. ${ }^{18}$ By contrast, a reading through a Senecan lens seems to reveal Lucan as a thoughtful Stoic who was interested in showing up the social and philosophical flaws in the Republic which allowed the Empire to come into being, while lamenting the violence and despotism that the empire all too often embodied. This was an agenda which would have been very much in harmony with Seneca's dream of an enlightened emperor ruling in accord with the Senate. ${ }^{19}$

Lucan highlighted many of his thoughts or concerns through the establishment of sharp contrasts and clear dividing lines such as those showing the savagery of Caesar as opposed to the more passive character of Pompey. In such a context, the concept of the finitor takes on a metaphorical role. Not only is it a perceived reference point for Cato's travels, but it is a philosophical dividing line between the world of Cato and the world of Caesar. The literary device involving the concealment of the stars heightens this contrast when viewed against astrological comments found in writers such as Pliny the Elder and Vitruvius.

Pliny explains in his encyclopedic work on natural history that certain constellations, which might be visible in Attica, may not be visible in Egypt or Syria; he cites Caesar as providing

\footnotetext{
${ }^{17}$ Sen. $Q N$ 5.17.3; Mart. Cap. 8.816-836. See: Wik Vol. 2, 189-191 for examples of some partial parallels to some of Lucan's verbal usage.

${ }^{18}$ Conte $1999,440,443-445$.

${ }^{19}$ Griffin 1992, 39-59; 2000, 70-76.
} 
many of the observations which made such an explanation possible. ${ }^{20}$ Vitruvius, presumably drawing on some of the same observations and information, explains that it is a marvel to behold that the equinox does not occur at the same rate or time at different places on Earth and digresses into an explanation of how the constellations revolve around the earth. ${ }^{21} \mathrm{He}$ later draws on this information to explain the construction and function of a sundial. ${ }^{22}$ Beginning by mentioning the lengths of equinoctial shadows at different latitudes he says:

Therefore, in whatever locations sundials must be marked out, one must begin with the equinoctial shadow of the place. And if the shadows are eight ninths of the gnomon as at Rome, let a line be drawn on a flat surface and from the center let a perpendicular plumb line be erected so that the plumb, which is called the gnomon, is like a carpenter's square. And from the line which is on the flat surface let the space on the line of the gnomon be divided into nine parts by the compass and, at the point which is designated as the ninth part, let a centre point be established where there will be a letter A. From this central point, the compasses should be extended to the line in the plain where there will be a letter B. The circumference of a circle, which is called the meridian, should be described. ...And let a line be drawn through the center of the circle so that there are two equal semi-circular divisions. Mathematicians call this line the horizon. ${ }^{23}$

The mention of the horizon in the construction of a sundial, along with the concept of the meridian, when taken with Seneca's remarks on the finitor and the nature of the description of Africa in Lucan, suggests that there may have been a temporal as well as a spatial component to the philosophical concepts of this boundary. Such an understanding should not be surprising, for, as D. C. Feeney noted in his 2007 publication, space and time are related and neither is absolute. Both space and time are perceptions used to order and organize events and their relationships. ${ }^{24}$ Thus, a boundary, which was dependent on the perception of astronomical phenomena for its delineation of space, could, and probably did, also have a similar function in the perceived delineation of time. In the case of Lucan's use of finitor in the Bellum Civile, the line represented by the coast of Libya would act as a navigational aid

\footnotetext{
${ }^{20}$ Plin. NH 18.246-248.

${ }^{21}$ Vitr. Arch. 9.1.1-8.

${ }^{22}$ Vitr. Arch. 9.7.1-6.

${ }^{23}$ Itaque in quibuscumque locis horologia erunt describenda, eo loci sumenda est aequinoctialis umbra, et si erunt quemadmodum Romae gnomonis partes novem, umbrae octo, linea describatur in planitia et e media pros orthas erigatur [ut sit ad normam] quae dicitur gnomon. Et a linea, quae erit planities, in linea gnomonis circo novem spatia dimetiantur; et quo loco nonae parties signum fuerit, centrum constituatur, ubi erit littera A; et diducto circino ab eo centro ad lineam planitiae, ubi erit littera B, circinatio circuli describatur, quae dicitur meridiana. ...Et per centrum perducendum, ut aequa duo hemicyclia sint divisa. Haec autem linea a mathematicis dicitur horizon. (Vitr. Arch. 9.7.2-3).

${ }^{24}$ Feeney 2007, 12.
} 
for Cato in his journey. It also served as a metaphorical/temporal division between two world ideas: Cato's vision of the Republic, and Caesar's world of the dictator.

It is clear that for Seneca and his contemporaries the transgression of such a boundary was an extremely dangerous proposition. However, if the transgression was undertaken for the sake of pure philosophical knowledge and the bettering of the human race, it would seem that Seneca and his circle could accept and justify the moral and physical risks they felt were involved. But any transgression made for the sake of self-aggrandizement or naked imperial greed was an invitation to moral degeneracy and destruction. ${ }^{25}$

The extent to which this philosophical concept was embedded in the Roman consciousness is revealed in the plot of the Thebaid of Statius. Drawing on the material of Greek mythology, the poet narrated the story of the campaign of the Seven against Thebes in a somewhat episodic fashion. As D. C. Feeney has pointed out, this episodic structure is part of the poet's art in delaying the action and expanding on the epic nature of his material while creating an environment of tension. ${ }^{26}$ In doing so, he relies on the constant energy of the Furies from Hell stirring up the events of mortal men as a vehicle to carry the plot forward in a world that seems simply to capture chaos. ${ }^{27}$ Characters representing dynamic opposites constantly come into conflict and violate the bounds of morality and social propriety. Such personal conflict follows closely the character of Lucan's Bellum Civile and, to a more limited extent, the epics of Virgil and Valerius Flaccus, reflecting a concern for one aspect of the nature of boundaries. ${ }^{28}$ At the same time, Statius creates a world image, which is far more concerned with another sort of boundary that is far more in accord with the concept of the finitor (as it was articulated by Seneca in his Natural Questions). Instead of a world divided in two by the Horizon, Statius articulates a three-fold division of existence, loosely rooted in the Virgilian mould of the Aeneid, but with a far more dark and sinister image. In this conceptualization of creation, the world was divided between Heaven, where Jupiter rules on high, Earth where humankind resides, and Hell, where Dis and the infernal shades of the dead create a sort of anti-Heaven in opposition to Jupiter. ${ }^{29}$ In principle, the boundaries between the three realms should have been inviolate, at least to humans. However, throughout the epic various

\footnotetext{
${ }^{25}$ Feeney 1991, 332-8. Romm 1992, 145-171 provides a most thorough examination of the concept.

${ }^{26}$ Feeney 1991, 340.

${ }^{27}$ Feeney 1991, 341.

${ }^{28}$ Masterson 2005, 291-292; Feeney 1991 350-2.

${ }^{29}$ Feeney 1991, 344-346; 358.
} 
characters constantly violate the boundaries of the three-fold system with the humans bursting into both Heaven and Hell. ${ }^{30}$ The physical and moral violations only come to an end when the gods and, more importantly, the Furies withdraw from the action and the human king Theseus arrives from Athens to restore order.

In such an environment, it would seem quite appropriate for Statius to bring up the concept of the finitor and, given the influence of both Flaccus and Lucan, both of whom were heavily influenced by the work of Seneca, it might be expected that Statius would invoke the term in a manner similar to that of the works already examined. Indeed, there are elements of that philosophical use of finitor in the Statian incarnation, but there are also surprising reflections of the Plautine use of the word which deserve consideration. Statius places the word finitor in the mouth of the Argive prophet Amphiaraus as part of a speech which is intended to answer the question asked by Dis as to what kind of death Amphiaraus might like, since he has come to Hell while still alive. ${ }^{31}$ Amphiaraus explains that he has not come to make trouble for Dis, but rather, the ground has swallowed him up while in the midst of battle and that it is the doing of his scheming wife. ${ }^{32}$

If it is right and proper for sacred shades to open their mouths here, $\mathrm{O}$ greatest delineator (finitor) of affairs for all mankind, but for me a progenitor (sator) too, I, who once knew the causes and elements, beg you soothe your threats and agitated heart. Do not think one who is mortal and afraid of your authority to be worthy of your wrath. ${ }^{33}$

Mark Masterson, in a masterful article, recently subjected this passage to a rigorous literary dissection which deserves to be quoted in part. He says:

There are a number of things to consider in Amphiaraus' words here. In the first place, Amphiaraus addresses Pluto as finitor. At the level of the plot, Pluto is the one who sets bounds to life and marks its end for all things. Indeed, Pluto is setting the bounds to the limes of Amphiaraus - he reaches now the end of both chariot-ride and life. ... Thinking further about finitor (and looking forward to sator), a reader will do well to remember that a finitor is also an agrimensor or landsurveyor (TLL VI.1.803.72-83). Significant for our purposes here, determining limites (paths) was among the duties of the agrimensor. Once the

\footnotetext{
${ }^{30}$ Stat. Theb. 7.818-8.36, 10.831-836.

${ }^{31}$ Stat. Theb. 8.84-85.

${ }^{32}$ Stat. Theb. 8.90-120.

${ }^{33}$ Si licet sanctis hic ora resoluere fas est /manibus, O cunctis finitor maxime rerum/ (at mihi, qui quondam causas elementaque noram, let sator), oro, minas stimulataque corda remulce,/ neue ira dignare hominem et tua iura timentem. (Stat. Theb. 8.90-94).
} 
work of the agrimensor/finitor was completed, the ownership of the field was secure and the sowing of the seed could occur. ${ }^{34}$

Masterson's observations about Pluto as one who establishes boundaries, both in terms of the poem and in terms of human existence, are profound and true, but they do not push the concept far enough. Examining the attribution further in light of Seneca's and Lucan's application of the word shows a double meaning. The expression cunctis finitor maxime rerum expresses both an occupational and an attributive or functional role for the term finitor. Pluto is simultaneously the one who establishes boundaries and the boundary itself. In this sense, finitor almost takes on a verbal attribution which would probably be quite appropriate and normal in Greek, but which is strange and unsettling in Latin.

As a verbal, or at the least functional attribution, finitor is here part of a deep philosophical concept which was very much part of the intellectual climate of Rome in the latter half of the first century A.D. This philosophical concept is signaled and embodied in the Thebaid by cunctis and includes the following line in which Amphiaraus establishes himself not only as a prophet, but as a philosopher who 'once knew the causes and elements.' Both causa and elementum were Latin words, which carried a strong sense of 'poetic generation,' in addition to connotations involving the inner workings of natural philosophy, particularly physics.

The role of Dis in this passage is underlined by the use of sator, a term of generation which might seem out of place in connection with the role of Dis as lord of death and endings. However, the word here probably serves four separate functions. First, there is a double literary function in which sator serves to link the description of the underworld in the Thebaid to that of Virgil's Aeneid, the natural punishment of the dead, and the concept of reincarnation through the Elysian Fields, which is a possible, though unlikely, fate for Amphiaraus. ${ }^{35}$ Second, sator is a term, which is almost always used in connection with Jupiter in the Thebaid. ${ }^{36}$ As Masterson observed in his article, there is only one other instance in the Thebaid where the word is not used in connection with Jove and there it is connected to the Eumenides. ${ }^{37}$ Given this, it seems obvious that the word's connection to Pluto here was intended to reinforce the identity of Pluto as the Jupiter of the lower world. This usurpation of

\footnotetext{
${ }^{34}$ Masterson 2005, 302.

${ }^{35}$ Verg. Aen. 6.724-751 against Stat. Theb. 8.21-130. Compare particularly Verg. Aen. 6.735-742 with Stat. Theb. 8.21-31, and Verg. Aen. 6.743 with Stat. Theb. 8.84. Also see: Masterson, 303 on this point.

${ }^{36}$ Stat. Theb. $1.179 ; 3.218,488 ; 5.22 ; 7.155,734 ; 9.511 ; 11.248$.

${ }^{37}$ Stat. Theb. 12.559; Masterson 2005, 302, n.24.
} 
Jove's identity is established by Pluto's speech invoking the Furies in the lines preceding Amphiaraus' speech and his nod of affirmation at its end, which shakes the ground even as Jupiter's nod shakes the heavens. ${ }^{38}$

In addition to these two literary functions, sator serves the philosophical function of establishing Dis or Pluto as part of the natural order and consequently tied him to finitor, agriculture, and the cycle of regeneration. The connection between these four features is introduced at the end of Dis/Pluto's speech invoking the Furies at the beginning of Book Eight. In these lines, Dis mentions that he had once stolen his bride from Sicily and, as a consequence, was granted only half the year with her. ${ }^{39}$ This is a clear reference to the Rape of Persephone, where Persephone spent half the year with her husband Dis/Pluto and half the year with her mother; this was an arrangement established by Jupiter to both punish and placate his brother, while insuring that the cycle of agriculture would go on. Because of this, Dis/Pluto was tied to the agricultural year and the cycle of rebirth represented by the return of spring. This change from winter to summer, represented by Persephone's migration from the Underworld, reflects a cycle with clear temporal boundaries and, as was indicated above, the finitor was a concept embodying both physical and temporal boundaries. Thus, as finitor maxime rerum, it seems likely that the agricultural cycle's "limites" would be among those boundaries which Dis/Pluto would have regulated.

As an extension of this regulation of the agricultural cycle, there is also the agricultural identification linking the finitor to the establishment of limites. As Masterson noted in his article quoted above, the TLL equates finitor with agrimensor. This association, as will be seen, is probably incorrect, but, as the quotation from Plautus mentioned at the beginning clearly shows, there was without a doubt a time when the finitor was charged with establishing limites. Thus, by deploying the term finitor between a phrase using limes and another using sator, Statius managed to invoke the agricultural meaning of finitor while reminding the reader of its philosophical attribution. Anything that might divide when used as a boundary could also unite when used as a path, and those things ended or separated in death are renewed through rebirth. Since epic poetry embodied these ideas, it could invigorate, enable, and immortalize, as Masterson argued in his article. ${ }^{40}$ What was more

\footnotetext{
${ }^{38}$ Stat. Theb. 8.36-85.

${ }^{39}$ Stat. Theb. 8.61-64.

${ }^{40}$ Masterson 2005, 303-4.
} 
important still, from a literary and historical standpoint, was that Statius, by simultaneously calling up both the agricultural and philosophical meanings of finitor in this context, established himself not only as a man of letters, but as a student of philosophy and a genius in his own right as a poet. No other author in antiquity managed to use both meanings of finitor in a single sentence.

In stark contrast to the convolutions of Statius' epic, the use of finitor in the satire of Persius is far more pedantic. However, as providing the first historically attested use of the word after Cicero's De Lege Agraria of 63 BC, the satires provide some interesting food for speculative thought on the term's evolution. Persius employs finitor in the final lines of his sixth and last satire, which was written on the subject of enjoying one's own property regardless of an heir's expectations. The satire seems heavily charged with ammunition from the Stoic creed against greed and miserly conduct. Because of this, the satire seems to be strongly influenced by the Epistles and Odes of Horace. ${ }^{41}$

Sell your soul for profit. Engage in trade and slyly dupe every part of the world, lest there be someone who is your superior at slapping Cappadocian fat on the rigid slave platform. Double your fortune. I did; now it is tripled, now quadrupled for me, now it returns ten times fold. Show me where I might stop. Chrysippus! A delineator for your pile has been found. ${ }^{42}$

The heir here has been consumed by his own greed, and needs someone (a finitor) to tell him where to stop. In this respect, finitor here has the same force that it has in Statius' Thebaid. The work simultaneously describes a person and the action which the person will be performing, suggesting that Statius may have drawn his inspiration from Persius as much as from Plautus.

The reference to Chrysippus' pile is an allusion to a Stoic conundrum going back to the foundation of the school. Called the Sorites, it asked at what point a collection of items becomes or ceases to become a pile. ${ }^{43}$ Chrysippus, who was the Stoic school's second head after Cleanthes, introduced this philosophical question. By referring to this intellectual knot, Persius indicated that anyone who could tell his hypothetical heir when, or more properly

\footnotetext{
${ }^{41}$ See for example: Hor. Epist. 2.2.87-204; Hor. Od. $2.2 ; 2.3 ; 2.14 ; 2.15$.

${ }^{42}$ Unde animam lucro, mercare atque excute sollers /omne latus mundi, ne sit praestantior alter /Cappadocas rigida pinguis plausisse catasta, /Rem duplica. Feci; iam triplex, iam mihi quarto,iiam decies redit in rugam. Depunge ubi sistam,/ inuentus, Chrisippe, tui finitor acerui. (Pers. Sat. 6.75-80).

${ }^{43}$ Cic. Acad. 2.92-94.
} 
where, to stop accumulating wealth would be a man who could solve the riddle. It must be admitted that finitor in this passage has none of the cosmological force found in the other three passages examined here, but as the first imperial testimony of the word it does establish the strong moral force of the term and ties that force to the philosophical cosmology of the Stoics.

It is almost impossible to state without qualification when or how finitor took on its meaning as a philosophical boundary, but the spatial and temporal aspects of that philosophical boundary suggests that the transformation took place after the completion of Agrippa's world map and the Augustan introduction of the Julian Calendar as an imperial standard for marking time throughout the Roman world. ${ }^{44}$ Such a monumental statement of control over spatial and temporal perception as these symbols represented would have, by definition, transformed the ways in which people conceptualized and articulated their understanding of both space and time. Philosophy, as the principal expression of an organized articulation of such thought processes, would have by necessity required adaptation to cope with the new intellectual climate. That adaptation would have required new words for talking about new ideas. The fact that the term finitor, as a word for talking about the new conceptualization of space and time, first appears in a Stoic context suggests that the word underwent its transformation in the hands of Stoic thinkers. ${ }^{45}$ If this is correct, the change must have been brought about through one of the Stoics who worked at Rome between 2 B.C., when Agrippa's map was finished, and the advent of Nero in A.D. 54. The time gap can be reduced even further by the fact that existing evidence indicates that most philosophers in the age of Augustus and Tiberius not only preferred to work in Greek, but were Greek themselves. ${ }^{46}$ This narrows the gap for the change to the few Latin-speaking Stoics active from the later years of Tiberius' reign to that of Nero, suggesting that the most likely candidate for initiating the change in the use of finitor was the Stoic thinker Fabianus. ${ }^{47}$

\footnotetext{
${ }^{44}$ On the introduction of the Julian calendar throughout the Roman Empire, see: Hannah 2005, 232-54, and Feeney 2007. On the world map of Agrippa see: Nicolet 1991, 96-118. His views have been challenged by the minimalist and highly skeptical interpretation of Kai Brodersen. See: Brodersen 1995, 265-87. However, his views seem rather restrictive and unconvincing when the map is considered in context with the Ara Pacis and Horologium Augusti as part of the monuments of the Campus Martius. For a summary of these monuments and their locations see: Wiseman 1993, 220-227.

${ }^{45}$ It may only be a collateral detail, but the Stoics seem to have had an intense interest in boundaries in general. See: White 2003, 150-151.

${ }^{46}$ Inwood 2005, 13-14.

${ }^{47}$ Inwood 2005, 14-15.
} 
The exact circumstances of the change can not even be guessed at, but whatever they were, the change was most certainly influenced by the fact that finitor seems to have dropped out of use as a term for describing someone who established boundaries. That function had fallen to the word mensor by $40 \mathrm{BC}$ if the writings of Varro have been properly dated. ${ }^{48}$ Whether that change in terminology also encompassed a change in occupation is an issue which can only be resolved through an examination of the Republican texts to establish exactly what the term meant to Romans of the Republican period.

\section{THE REPUBLICAN TEXTS}

Of the two texts from the Republican Period, that of Plautus in his Poenulus remains not only the earliest, but also the most straightforward. It is certainly the text that most modern scholars use as a starting point when considering the history of the Roman Surveyors. ${ }^{49}$ The reference occurs in the introduction to the play and forms a metaphor through which the play's narrator likens himself to a surveyor.

Now I wish to once again to return to the conflict so that you will know as much as I. I will presently establish the regions, the limits, and the boundaries of this play: I have been appointed as a divider (finitor) for the task. ${ }^{50}$

The language employed by Plautus in this metaphor to describe his duties as narrator is most revealing. He states that he has been appointed as a divider 'finitor factus sum', indicating that finitores were individuals who were not elected by the Roman people but 'made. ${ }^{51}$ As appointed individuals, the finitores would have derived their duties, responsibilities, and authority from another organ of the Roman Republican government. Plautus does not specify from whom he might have gained his appointment as a so-called finitor, but it is likely that anyone serving as a finitor would have held the post only as long as the official who appointed the finitor held office. Such a procedure was the norm for other appointed officials such as lictores. ${ }^{52}$

\footnotetext{
${ }^{48}$ See: Varr. $R R$ 1.1.10; 1.14.1-1.16.6; 3.1.6; 3.17.9 and Conte 1999, 211.

${ }^{49}$ See: Classen 1994, 163; Gargola 1995, 46-47.

${ }^{50}$ Plaut. Poen. 49-50. See: n. 1 of this chapter for the text.

${ }^{51}$ For a similar use of the term factus to indicate appointment to a temporary post by a higher official, see: $A E$ 1969-70.0583 = $A E 1974.0589=A E 1985.0721$.

${ }^{52}$ For lictores see: TLL 7.1374-1377. For other related officials, see: TLL 2.268-269; 2.374; 10.495-500.
} 
Plautus indicates some of the functions of the finitor and by extension the identity of the Republican officials to whom the office was responsible with the words 'eius nunc regiones, limites, confinia determinabo...' The terms regiones and limites have multiple meanings, and are in themselves vague. But the terms confinia and determinabo in the context of Roman Republican law, possessed a distinct meaning which was attached to the establishment of 'boundaries' for land under the jurisdiction of a colonia. ${ }^{53}$ Such a connection suggests that the Roman Republican finitor was responsible for at least marking, if not actually measuring out, the boundaries of land assigned to Roman colonists. By extension, it also suggests that the finitores were responsible to, but not necessarily appointed by the triumviri. ${ }^{54}$

The task of establishing the boundary markers for colonial land places the finitor in the midst of the Roman agricultural system. As C. A. Francese noted in his book on the Latin language, the concept of the colonia was drawn from the principle that Roman veterans discharged from the army were granted land in newly conquered territory with the expectation that they would both farm and defend it as coloni or tenant farmers. ${ }^{55}$ From at least the end of the third century B.C., exact boundaries were essential for the organization and administration of such a settlement, and, as the text of Statius examined above indicates, the agricultural connotations of the finitor's identity at least partially survived to the end of the first century A.D. when the term had gathered other meanings.

In addition to his agricultural function, the work of the finitor in the establishment of colonial boundaries indicates that those who held the post performed a ritual function too. The nature of such a function would have been determined by the fact that all public space in the Roman world was delineated by ritual action and ceremony which was intended to establish its purpose. ${ }^{56}$ Thus the nature of the rituals performed and the individuals required to perform them was governed by the intended function of the space.

The most notable such ritual of this sort was the one that established the outer boundary of the urbs in a colonial context. The ceremony had to be performed by an official who possessed imperium since the boundary of the colonial urbs delineated the jurisdiction of

\footnotetext{
${ }^{53}$ Sic. Flac. De Con. Agr. 102.5-8 For confine see: TLL. 4.216-217. For determinare see: TLL 6.801-804.

${ }^{54}$ For a full discussion on the identity of the triumviri and their duties, see: Gargola 1995, 59-63 \& 73-98.

${ }^{55}$ Francese 2007, 75 and by way of support, Campbell 2000, 368, n.4.

${ }^{56}$ Linderski 1986, 2, 16.3, 2271-2304; Gargola 1995, 31-39.
} 
military power. ${ }^{57}$ Because the action that established this boundary was a ritual one governed by Roman religious law, it may be assumed that one or more of the augurs oversaw it. As the guardians of Roman ritual, it was up to that religious college to establish whether or not a ritual was acceptable to the gods and therefore valid.

If in turn, the finitores were responsible for establishing colonial boundaries outside the urbs, as the text of Plautus suggests, then they should have performed an analogous ritual, particularly since boundary stones were sacred to the god Terminus. ${ }^{58}$

In considering the text of Plautus, D. J. Gargola offers up another valuable observation for understanding the character of the finitor as it is presented in the Poenulus. He notes that while Plautus attached the identity of the finitor to the establishment of regiones, limites, and confinia, he made no remarks that specifically tied the finitor to the system of centuriation used to establish the field systems of coloniae in the late Republic. ${ }^{59}$ All three surveying terms employed by Plautus have a variety of interpretations. And even confinia which almost always reflect boundaries attached to a colonia can refer to a number of different boundary systems recorded by archaeological investigation. Many of those systems only loosely reflect the highly systematized and exact grid pattern embodied by centuriation. This opens up the very real possibility that the origin of the finitor and triumviri predated the development of centuriation. Roman coloniae go back to the earliest days of the Republic, but the practice of centuriation can only be traced in settlements from the end of the third century B.C. onward. So that while it is true that an early date in the fourth or fifth centuries B.C. can not be substantiated on the surviving evidence, it would seem logical that the offices associated with the establishment of coloniae would evolve in tandem with the institution they served. ${ }^{60}$

Even if the role and origins of the finitor in the years before Plautus can only be guessed at, their role in Republican life in following years is to some extent illuminated by Cicero's second speech against the Rullan land bill of 63 B.C. Intended to persuade the Roman plebs to vote against the law, the speech is highly rhetorical, prone to exaggeration, and even bombastic. Nevertheless, it was effective and provides a dynamic contrast to the view of the finitores gained from Plautus and the imperial texts.

\footnotetext{
${ }^{57}$ Gargola 1995, 74-75.

${ }^{58}$ Sic. Flac. De Con. Agr. 106.24-108.5; Gargola 1995, 45; Campbell 2000, 371 n.14.

${ }^{59}$ Gargola 1995, 91-92.

${ }^{60}$ Gargola 1995, 41-9; Campbell 2000, LVII-LXI; Chouquer 2001, 79-91.
} 
In addition, he (Rullus) grants praetorian power in name, but it is kingly in reality. He limits that power to a five-year tenure, but makes it perpetual. Indeed he reinforces them (decemviri) with such resources and forces that it will scarcely be possible to take power back from them against their will. In addition, he also furnishes them with clerks, scribes, copyists, heralds, architects, mules, tents, multicolored saddlecloths, and all the paraphernalia necessary for business. He drains the money for their expenses from the treasury, supplies even more from the allies. He appoints two hundred dividers (finitores) from the ranks of the equites so that there are twenty personal attendants for each, agents and accomplices of their power.

Now here gentlemen, you have the form and very essence of tyrants. You can see all the insignia of power, but you do not yet see the power itself. But perhaps someone may say: "But what harm do these people, scribes, lictors, heralds, and chicken-feeders, do me?" All of these things are of the sort, gentlemen, that should someone possess them without your votes, then he must either be an insufferable monarch or else, as a private citizen, he would appear to be a madman. ${ }^{61}$

Here, Cicero, introducing the finitores to his audience for the first time, describes them not as surveyors, but as greasy hangers-on or followers of the decemviri who will act as aids and accomplices in the crime of stealing land from honest citizens. Much of the language is clearly rhetorical polemic aimed at tearing down Rullus. Even so, the fact that the finitores are not specifically named as surveyors suggests that either the audience had little actual knowledge of their function, or Cicero could use them as stock characters of tyrannical power. Or else his audience was so familiar with their function that the name itself was synonymous with their role in surveying and land distribution. The reference in Plautus along with the other three references to finitor in Cicero's speech suggests the latter. ${ }^{62}$ Such a familiarity may explain why there is so little reference to finitores in surviving literature. They represented something so well known that it did not require much comment and the concept that they represented was one which was so devoid of intellectual interest that the aristocratic writers of the late Republic felt little inclination to write about it.

\footnotetext{
${ }^{61}$ Dat praeterea potestatem verbo praetoriam, re vera reginam; definit in quinquennium, facit sempiternam; tantis enim confirmat opibus et copiis ut invite eripi nullo modo possit. Deinde ornate apparitoribus, scribis, librariis, praeconibus, architectis, praeterea mulis, tabernaculis, centunculis, supellectili; sumptum haurit ex aerario, suppeditat a sociis; finitores ex equestri loco ducentos, vicenos singulorum stipatores corporis constituit, eosdem ministros et satellites potestatis. Formam adhuc habetis, quirites, et speciem ipsam tyrannorum; insignia videtis potestatis, nondum ipsam potestatem. Dixerit enim fortasse quispiam: 'quid me ista laedunt, scriba, lictor, praecox, pullarius?' Omnia sunt haec huius modi, quirites, ut, ea qui habeat sine vestris suffragiis, aut rex non ferendus, aut privatus furiosus esse videatur. (Cic. De Leg. Agr. 2.32). For supporting documentation on the support staff assigned to triumviri and decemviri, see: Liv. 42.1; Plut. Ti. Gracch. 13.

${ }^{62}$ Plaut. Poen. 48-49; Cic. De Leg. Agr. 2.34, 45, 53.
} 
What is far more important is the social character Cicero assigns to the finitores. He explicitly labels them as being equestri loco or as coming from the equestrian order, an observation which Cicero's polemic might lead us to question. However, there are four sound reasons for accepting the accuracy of Cicero's characterization of the finitores as equites. First, there is the fact that the imperial authors already examined attached a sense of strong moral virtue to the use of the word finitor. Moral virtue was a trait that was traditionally attributed to members of the Roman aristocracy, though, as Cicero and Sallust cynically remark, it was a characteristic which not all nobiles and equites possessed in the late Republic. $^{63}$

Second, there is the fact that if Rullus wanted to assign equites to his land commission as finitores against the normal custom, Cicero as a defender of that order could not have failed to make political hay of the matter. Cicero would most certainly have accused Rullus of tarnishing the dignitas of the equites, scoring a political point against his adversary. However, while Cicero does attack Rullus personally on several occasions, he does not seem to attack him for appointing equites to posts which are beneath them.

Third, Cicero elsewhere refers to the finitores as being iuvenes or youthful:

What do you think the opinion, the dread, and the danger will be in those wreched nations when the Board of Ten with their military power (imperium), their fasces, and that hand-picked youthful band (iuventus) of dividers (finitores) go wandering all over the entire world? ${ }^{64}$

Iuventus was often used as a shorthand expression referring to young men of the equestrian order. Cicero and Sallust both make frequent use of the term in their writings. ${ }^{65}$

Fourth, there is the position of the expression equestri loco. This expression is separated from the list of other functionaries serving with the decemviri. This separation itself suggests that the two groups were of a different social comparison and function.

\footnotetext{
${ }^{63}$ Nicolet 1970, 89-97; Francese 2007, 52-3, 58-60, 114-123, 217-228.

${ }^{64}$ Quid censetis, cum isti xviri cum imperio, cum fascibus, cum illa delecta finitorum iuventute per totum orbem terrarium vagabuntur, quo tandem animo, quo metu, quo periculo miseras nationes futuras? (Cic. De Leg. Agr. 2.45).

${ }^{65}$ Sall. BC 14, 16, 17; Cic. De Leg. Agr. 45.
} 
As an additional point, the introduction of the finitores by Cicero has the list of attendants and the announcement of the finitores' appointment separated by an accusation of embezzlement of public funds; 'sumptum haurit ex aerario'. This accusation and its location in the text suggest that the finitores served without pay. At the same time, it seems likely that the finitores would have received an ex gratia payment much as jurists such as Cicero often did. This is a supposition that receives some support from jurists in the Imperial period who mention that there were times when surveyors were not supposed to charge a fee for their services. ${ }^{66}$ If the finitores did not receive any remuneration for their services, as the other attendants seem to have done, then it follows that the finitores must have come from the propertied classes.

Establishing that the finitores were young men drawn from the equestrian order still leaves a social identity problem since as several scholars have pointed out, the equites were a large disparate group in the late Republic. ${ }^{67}$ On the one hand, the label of equites covered the sons of the nobiles who had not yet held political office. On the other it also covered wealthy landowners from Italy who were accepted into the circle of the socially respectable rich at Rome. Claude Nicolet in 1970 was of the opinion that the finitores were probably drawn from the traditionally wealthy men at Rome who were rated in the census class which enabled them to possess a horse at public expense. ${ }^{68}$ In other words, they were rated in the class of the traditional hereditary equites.

In considering the social identity of the finitores and their role in Roman society, it is also worth looking at one interesting departure Cicero makes in his speech, the employment of finitor in a purely negative context.

And I suppose, Publius Rullus -since he is already conducting himself so that it would appear he has already been elected to the Board of Ten (decemviri) — will principally proceed to this auction. Evidently, even before he arrives in Pontus, he will send letters to Gnaius Pompey, of which I imagine a specimen has already been drafted: "Servilius Rullus, Tribune of the Plebs, member of the Board of Ten greets Gnaius Pompey son of Gnaius." I do not believe he will add "The Great" since it does not seem likely that he will concede something in a word which he is attempting to diminish in substance. "I wish you to make arrangements so that you can meet me at Sinope and provide me with assistance while I in accordance

\footnotetext{
${ }^{66}$ Just. Dig. 11.6.3.

${ }^{67}$ Nicolet 1970, 98; Francese 2007, 53

${ }^{68}$ Nicolet $1970,99-103$.
} 
with my law, sell those lands which were won through your effort." Or will he not invite Pompey? Will he sell off the general's share of the plunder in the general's own province? Picture it for yourselves, Rullus with his handsome land-grabbers (finitores) conducting the auction between our camp and that of the enemy. ${ }^{69}$

In this rhetorical blast of contempt, Cicero uses the word finitor with the same force and derisive abuse he loads into latro. ${ }^{70}$ This does not mean that finitor normally carried negative overtones, or that there was any shame attached to holding the office.

What the passage does show, apart from Cicero's contempt for Rullus, is a rare glimpse of a decemvir interacting with his finitores. If the passage reflects some semblance of reality, then the decemviri could when necessary operate individually, using their finitores as agents to perform essential tasks in the ritual assignment and / or sale of land. The fact that the finitores seem to have been involved in more than the simple measurement of land is an important addition to the information provided by Plautus, showing that they were not just functionaries who marked out territory to the dictates of their senatorial superiors. Cicero does not clearly state what all the tasks of the finitores may have been in the hypothetical auction of land he describes, but a further passage from his speech suggests that those duties may have involved assessing the value of land and assisting with the collection of money for its sale or purchase.

...They will be able to buy land from whomever they might wish and whatever they might wish at whatever high price they might want. Permission is being granted to them to establish new colonies, refurbish old ones, and to fill all of Italy with their colonists. The highest authority is being granted for visiting all the provinces, for punishing free peoples through the confiscation of their territory, for the sale of kingdoms! It is allowed as lawful that when they wish, they can be at Rome, when it is convenient and that they may wander wherever they might please with absolute power and judicial authority. They may dissolve the public tribunals, dismiss anyone whom they might wish from the public debates, individually adjudicate the gravest of matters, authorize a quaestor, dispatch a

\footnotetext{
${ }^{69}$ Et, credo, P. Rullus-is enim se gerit ut sibi iam xvir designatus esse videatur-ad eam auctionem potissimum proficiscetur! Is videlicet, ante quam veniat in Pontum, litteras ad Cn. Pompeium mittet, quarum ego iam exemplum ab istis compositum esse arbitror: "P. Servilius Rullus Tribunus Plebis xvir S. D. Pompeio Cn. F.," non credo ascripturum esse "Magno" non enim videtur id quod imminuere lege conatur concessurus verbo. 'Te volo curare ut mihi Sinopae praesto sis auxiliumque adducas, dum eos agros quos tuo labore cepisti ego mea lege vendam.' An Pompeium non adhibebit? In eius provincia vendet manubias imperatoris? Ponite ante oculos vobis Rullum in Ponto inter nostra atque hostium castra hasta posita cum suis formosis finitoribus auctionantem. (Cic. De Leg. Agr. 2.53).

${ }^{70}$ See: Cic. Phil. 2.3.5; 2.3.6; 2.4.9; 2.25.62; 2.34.87; 3.11.29; 4.2.5; 4.4.9; 4.6.15; 5.8.23; 5.11.30; 6.2.4; 6.5.12; 8.3.9; 11.2.4; 11.3.7; 11.6.14; 12.8.20; 12.10.26; 13.7.16; 13.9.19; 13.9.20; 14.3.8; 14.5.14; 14.7.21; 14.10.27. Contrasted with Cic. Rosc. 27, 56, 57 and Sall. BC 28, 59.
} 
divider (finitor), and ratify whatever the divider (finitor) has reported to the individual by whom he was sent. ${ }^{71}$

The independent initiative and power of both the decemviri and the finitores displayed in these passages may have only been a feature of their functions in the later Republic. Indeed, it is even possible that they were innovations introduced for the first time by the Rullan legislation which was never passed. Available evidence indicates that in the third and second centuries B.C., all the members of a land commission were obliged to operate together in one area. Evidence for this comes from the description of several land boards provided by Livy which were prevented from carrying out their tasks directly because one or more of their triumviri were detained elsewhere on official business. ${ }^{72}$ It was only in the tribunate of Tiberius Gracchus that the triumviri seem to have begun working independently of one another on multiple projects simultaneously. ${ }^{73}$ If this interpretation is correct, then it seems probable that the finitores were similarly circumscribed in their activities.

To go beyond the limited hypothetical portrait of the finitores in the first century provided by Cicero, we must once again turn to imperial texts to consider their relationship to the Republic. As should be evident from the discussion of the finitores' social identity above, the imperial use of finitor was an extrapolation or, perhaps more properly, abstraction of an earlier concept. The concept of the finitor as a boundary setter was extrapolated from the finitores' role in establishing limites. The high moral ideals attached to the word by the imperial authors were extracted from the republican office's equestrian status. The attachment of finitor to the concept of astronomy and more specifically the horizon also seems to have had a point of origin in the Republic.

Astronomy, according to the authors in the Corpus Agrimensorum, had a long association with and practical function in surveying. Indeed, Frontinus clamed that according to Varro,

\footnotetext{
${ }^{71}$ Iudicare per quinquennium vel de consulibus vel de ipsis tribunis plebis poterunt; de illis interea nemo iudicabit; magistratus eis petere licebit, causam dicere non licebit; emere agros a quibus volent et quos volent quam volent magno poterunt; colonias deducere novas, renovare veteres, totam Italiam suis coloniis ut complere liceat permittitur; omnis provincias obeundi, liberos populos agris multandi,regnorum vendendorum summa potestas datur; cum velint, Romae esse, cum commodum sit, quacumque velint summo cum imperio iudicioque rerum omnium vagari ut liceat conceditur; interea dissolvant iudicia publica, e consiliis abducant quos velint, singuli de maximis rebus iudicent, quaestori permittant, finitorem mittant, ratum sit quod finitor uni illi a quo missus erit renuntiaverit. (Cic. De Leg Agr. 2.34).

${ }_{72}$ Liv. 33.43.5-9; 34.10.1-7; 34.43.3-9; Gargola 1995, 68, 214-215.

${ }^{73}$ On the Gracchan land commissions, see: Gargola 1995, 149-173, particularly 155-162 \& 167-173. Further considerations are provided by: Braudhead 2007, 157-61. Also consult the references in the introduction n.16.
} 
the entire science of surveying owed its very existence to the Etruscan system of augury which was itself dependent on astronomy.

\begin{abstract}
Varro ascribes the original origin of limites to the Etruscan discipline which the soothsayers use for dividing the world into two parts. They called the land on the right hand when one is oriented from east to west as in the direction from which the sun and moon are observed, the northern zone, and the land on the left the southern. Similarly, some architects have written that temples should properly be constructed to face west. The soothsayers divided the land with another line from south to north, and from this meridian, they named everything on the far side of the line antica and that on the near postica. From this beginning, our ancestors seem to have established a plan for the measurement of land. First, they laid out two Limites; one from east to west, which they called the Decumanus, and one from south to north which they called the Cardo. Therefore the Decumanus divided the land into right and left, the Cardo into the near and far sides. ${ }^{74}$
\end{abstract}

While a pure Etruscan origin for Roman surveying practice is doubtful, there does not seem to be any sound reason for challenging Frontinus' evidence regarding the influence of the Etruscans on the role of astronomy in that activity. ${ }^{75}$ When one considers this information in conjunction with the astronomical attributes attached to finitor by Seneca and Lucan, it becomes fairly certain that the Republican finitores were not only responsible for marking out the limites of a colonia, they were also responsible for its orientation too.

Traditional rituals whose practices were governed by the augures probably governed the tasks of orientation, such as establishing the limites. There are some scholars who feel that the essence of these rituals if not their actual content can be recovered through a close reading of the introduction to the Poenulus, passages of Varro's work on the Latin Language, and Livy's history. ${ }^{76}$ In the case of the Poenulus, there is little doubt that the introduction

\footnotetext{
${ }^{74}$ Limitum prima origo sicut Varro descripsit, a[d] disciplina [m] Etrusca[m]; quod aruspices orbem terrarum in duas partes diuiserunt, dextra appellauerunt $<q u a e>$ septentrioni subiacere $<t>$, sinistram quae a meridiano terra $<e>$ esse $<t><a b$ oriente ad $>$ occasum, quod eo sol et luna spectaret, sicut quidam carpiunt architecti delubra in occidente $<m>$ recte spectare scripserunt. Aruspices altera $[m]$ linea $[m]$ a septentrione ad meridanum diuiserunt terram, <et> a me[ri]dia[no] ultra antica, citra postica nominauerunt. Ab hoc fundamento maiores nostri in agrorum mensura uidentur constituisse rationem. Prima duo limites duxerunt; unum ab oriente in occasum, quem uocauerunt decimanum; alterum a meridiano ad septentrionem, quem cardinem appellauerunt. Decimanus autem diuidebat agrum dextra et sinistra, cardo citra et ultra. (Front. De Lim. 8.22-8.34).

${ }^{75}$ There is plenty of evidence to suggest that the Romans drew the practical concepts of centuriation from the field systems found associated with Greek colonies in southern Italy, but that the religious and astronomical influences were derived from the Etruscans as Frontinus suggests in his writings. On these topics, see: Dilke 1971, 32-35; Gargola 1995, 41-50; Jameson 1990, 190-192; Edlund-Berry 2006, 116-131; and Briquel 2005, $121-133$

${ }^{76}$ See: Plaut. Poen. 5-96; Varr. LL 5.33; 6.86-92; 6.95; 7.6-13; Liv. 1.18.7-10; Gargola 1995, 35-39, 47-49; Slater 1992, 131-146. By way of contrast, also see: Linderski 1986, 2263-2289.
} 
contains a formulaic flavor. However, Plautus was a comic playwright, and any traditions recorded in his works need to be treated with care. It seems likely that if the introduction does contain a reference to rituals involving surveying, that allusion would form part of a stylistic joke involving the finitores which probably centred around events involving the establishment of coloniae in 194 B.C. which are beyond our ability to recover. ${ }^{77}$

Likewise, the texts of Varro and Livy record religious rituals for the creation of a templum. And no matter how much centuriation may seem to have in common with the establishment of the templum, the two were not the same. It is highly unlikely that the Romans, who were a highly legalistic and exact people, would use the same formula for two very different activities. Thus at best Varro and Livy can provide a rough feeling for the rituals performed for orienting a colonia under the republic. The best evidence for both the orientation of a colonia and the establishment of boundaries comes from the Corpus Agrimensorum, and reflects imperial practice. Even so, it provides an interesting perspective on methodology.

In a work attributed to the surveyor Hyginus, the author describes a single surveyor setting up the iron staff used to support the surveyor's cross or groma just before sunrise to find his orientation. The author later goes on to explain that to avoid error in this operation, a sundial should be used to obtain exact and accurate calculations. ${ }^{78}$

It is easy to imagine the finitores and the triumviri or decemviri assembling in the cold hours before dawn to observe the constellation of the Bear and the direction of the sunrise to orient their new settlement. Since none of the officials were formally trained as surveyors in the modern sense, it is likely that the triumviri and finitores relied on group consensus reached through the Roman practice of concilium to avoid any major mistakes. ${ }^{79}$ Such consensus and the need to organize large numbers of settlers may explain why the Roman Republican land commissions were composed of so many people while imperial ones operated with only a few mensores and a single founder.

In spite of the ritualistic nature of the finitores' work, the hierarchical relationship between the senatorial decemviri, triumviri and finitores suggests that the latter were appointed by the

\footnotetext{
${ }^{77}$ Liv. $34.45,34.53$, 35.9., 35.40, 39.44, 39.55. For an exact discussion on the events surrounding this colonial activity, see: Braudhead 2007, 151-156.

${ }^{78}$ Hyg. Lim. 136.18-21, 150.3-21.

${ }^{79}$ Francese 2007, 110-112.
} 
former through the normal system of patronage and political deal-making that made up so much of the Republic's governmental structure. If this was the case, then it seems likely that the actual number of finitores may have fluctuated depending on both the size of the colonial project and the influence of the colonial founders. Any attempt to establish a fixed ritual number based on the evidence of Cicero seems futile since his polemic renders any precise information into pure rhetoric which may or may not reflect reality.

Likewise, it is almost impossible to establish the extent to which the finitores actually came to grips with the technical aspects of their responsibilities. Some scholars have argued that the finitores were nothing but the mid-ranking administrators who oversaw work which was actually done by lower-class technicians. ${ }^{80}$ The limited access to higher education including literacy and mathematics in the early and middle Republic would seem to be against this, but such a situation may have come to pass by the time of Sulla. In this respect it may be significant that the account of rituals associated with the establishment of boundary stones in the text of Siculus Flaccus states quite clearly that the stones were set up by individuals with no mention of finitores, mensores, or any other official. ${ }^{81}$ In addition, Republican and Imperial texts do make mention of another body of men involved with surveying Roman army camps, called metatores, who were perhaps synonymous with the mensores under the Republic ${ }^{82}$ The texts do not seem to directly link these people to the establishment of coloniae. However, the division between civilian and military life under the republic was a thin one. And since the early coloniae were all established by drawing on veterans for military purposes, it is quite possible that the metatores took a hand in the work of the

\footnotetext{
${ }^{80}$ Classen 1994, 166-169 makes the case that men of the equestrian class would not have carried out the work of surveying, partially on the grounds of dignitas and partially on the grounds that technical knowledge such as the mathematics used for surveying wasn't part of the artes liberales. However, it is clear from a passage of Seneca's letters that Roman nobiles and equites did have access to advanced mathematics and all the skills needed for surveying. In addition, several branches of philosophy placed a high value on such training. The contempt for geometrae Seneca shows in his letter was probably partially a rhetorical trick to bolster the case for the study of philosophy, and partially a reflection of the fact that men of a lower social order were trained as surveyors in Seneca's day. Under the Republic, access to such higher education was almost certainly the province of the wealthy, making it far more likely that the equites would have been involved in such work. As a final point, it is unlikely that slaves could have carried out much of the work of surveying in the middle Republic as Classen suggests, since the only public slaves who can be identified were employed in the aerarium as record keepers. See: Sen. Ep. 88.10-12; Cic. De Or. 3.127; Isid. Etym. 1.2.1; Cic. Leg. 2.46; CIL. 5.6786; CIL. 6.1975; Zimmer 1982, 196-198; Moatti 1993, 69-73; Horsfall 2003, 51-63; Cuomo 2007, 106-107; Clarysse \& Vandorpe 2008, 731-736.

${ }^{81}$ Sic. Flac. De Con. Agr. 106.22-108.7.

${ }^{82}$ Cic. Phil. 11.12; 14.10; Luc. BC 1.382; Front. Strat. 2.7.12; Hyg. De Mun. Cast. 37.1; 46.3; Veg. Epit. Mil. 2.7.6. Also see: Chapter 2 below. Lucil. Fr. 100.
} 
finitores. To establish the identity of the metatores and their relationship to the finitores represents a whole new problem which both requires and deserves its own separate study. 


\section{CHAPTER TWO \\ METATORES AND MENSORES: MEN OF MEASUREMENT IN THE ROMAN ARMY}

There is also some fellow Saxa, whom Caesar has hoisted on us as a tribune of the plebs, although he comes from the furthest reaches of Celtiberia. He was previously a camp measurer (castrorum antea metator), but now, so he hopes, a city measurer. Since he has no links with our city, may this be an ill-omen on his head, without harm to us. ${ }^{1}$

Metatores are those who marching in advance select a location for the camp. ${ }^{2}$

As these two passages show, the metatores were a part of the Roman army. They seem to have been employed to select and set up the Roman temporary marching camps or castra. However, their social identity and exact duties remain something of a mystery. The fact that mensores or Roman land surveyors as well as metatores are attested as part of the army and responsible for various engineering activities, including camp construction might suggest, that the term metator was simply another name for the same occupation. ${ }^{3}$ However, such an argument is not generally advanced or accepted by modern scholars, who, when discussing the mensores or agrimensores as they are usually labeled in the literature, tend to set the metatores off to one side without evaluating either their identity or their relations with the mensores. Here we will examine the social identity of the metatores, their role in the Roman army, and their relationship not only to the mensores but to the Republican finitores as well.

It is not possible to say exactly when metatores were introduced to the Roman army. The earliest recorded role of these men in military activities dates to the Marian campaigns against the Cimbri in 102 B.C. ${ }^{4}$

Marius had faced off against the Cimbri and Teutones, when the metatores through extreme imprudence occupied a position for the camp that placed the water supply under the control of the barbarians. With his troops urgently demanding water, Marius indicating the enemy with his finger, said: "It must be

\footnotetext{
${ }^{1}$ Accedit Saxa nescio quis, quem nobis Caesar ex ultima Celtiberia tribunum pl. dedit, castrorum antea metator, nunc, ut sperat, urbis; a qua cum sit alienus, suo capiti salvis nobis ominetur. (Cic. Phil. 11.12).

${ }^{2}$ Metatores qui praecedentes locum eligunt castras. (Veg. Mil. 2.7.6).

${ }^{3}$ There is no separate study of the agrimensores in the Roman army, but see the discussion below and fundamentally Sherk 1974, 546-557.

${ }^{4}$ For a discussion on the identity of the metatores as mensores in the time of Marius, see: Chapter Three.
} 
obtained there." With this as inspiration, the army launched such an attack that the barbarians were immediately driven from the position. ${ }^{5}$

The text of Cicero quoted at the opening indicates that there is no reason to challenge Frontinus' assertion that metatores functioned in the armies of the later Roman Republic. And while Frontinus' remarks may cause us to question the professional competence of the metatores in the establishment of Roman camp-sites, it is worth remembering that he was not primarily interested in the metatores. His interest in the anecdote was to show how a clever commander could take advantage of necessity to overcome a major military setback. The metatores were a minor incidental trifle.

In general, other texts from both the Republic and Imperial periods indicate that the metatores were a fixed traditional institution. Lucan for example associated them with Caesar's imprudent occupation of Rome.

Come lead us amongst the Scythian peoples, along the inhospitable Syrtian shores, Or through the sweltering desert of arid Libya.

So that this army might leave behind a conquered world, It tamed the swollen waves of ocean with the oar and tamed the foaming Rhine at the Northern limit.

It's as important for me to be able to carry out my orders as to want to do so. He is not my fellow citizen against whom I hearken to your trumpet call. O Caesar. By the blessed signs in ten campaigns, By your triumphs against the enemy, I swear, That if you should order me to plunge my sword in the heart of a brother or the throat of a parent, Or in the unborn flesh of one's pregnant wife, I will nevertheless do it all even if my hand is unwilling. If you should order us to plunder the gods and fire their temples, The ardour of the soldiery will confound the divine spirits of the shrine. If you should order us to pitch our camp over the waters of the Tuscan Tiber, I will fearlessly come as measurer (metator) to the Hesperian plains. ${ }^{6}$

\footnotetext{
${ }^{5}$ Marius adversus Cimbros et Teutonos, cum metatores eius per imprudentiam ita castris locum cepissent, ut sub potestate barbarorum esset aqua, flagitantibus eam suis, digito hostem ostendens "illinc," inquit: "petenda est” quo instinctu assecutus est, ut protinus barbari tollerentur. (Front. Strat. 2.7.12).

${ }^{6}$ Duc age per Scythiae populos, per inhospita Syrtis / litora, per calidas Libyae sitientis harenas: / haec manus, ut uictum post terga relinqueret orbem, / Oceani tumidas remo conpescuit undas / fregit et Arctoo spumantem uertice Rhenum: / iussa sequi tam posse mihi quam uelle necesse est. / nec ciuis meus est, in quem tua classica, Caesar, / audiero. per signa decem felicia castris /perque tuos iuro quocumque ex hoste triumphos, /pectore si fratris gladium iuguloque parentis / condere me iubeas plenaeque in uiscera partu / inuita peragam tamen omnia dextra; / si spoliare deos ignemque inmittere templis, / numina miscebit castrensis flamma monetae; / castra super Tusci si ponere Thybridis undas, / Hesperios audax ueniam metator in agros. (Luc. BC 1.367-382).
} 
From the internal context, it would seem that not only did Lucan both assume that his audience knew what a metator was, he also expected them to be familiar enough with their role in military life to understand the allusion to the occupation of the banks of the Tuscan Tiber as Caesar's military domination of Rome. In addition, his reference displays several aspects of the metatores that are less clear from the texts of Frontinus, Cicero, and Vegetius. First, the metatores were closely associated with Roman geographic domination. This is to say that the metatores in marching in advance and constructing a castra asserted Roman military and political control over what was often an unknown or hostile wilderness landscape. ${ }^{7}$ The establishment of such control and by extension the introduction of civilization is highlighted in both Frontinus and Lucan by words such as barbarus, aqua, agri, and the like. This association with the establishment of civilization was also a characteristic feature of the mensores, which may have contributed to confusion amongst modern scholars over the differences between the two groups of "measurers", a matter which will be addressed below. ${ }^{8}$

At the same time that the metatores were shown as a force of domination and control, Lucan's language also shows that they could be an instrument of chaos and destruction. In describing the metator's role as soldiers tasked with establishing a marching camp in advance of the army, Lucan used the word audax; a word which meant bold or courageous to the point of being reckless or rash. As such, the term carried a clear pejorative meaning, particularly when placed in the context of geographic exploration. ${ }^{9}$ Thus Lucan makes Caesar's metatores simultaneously bold as an advance guard in the establishment of control or order and a force of rash unbridled, uncivilized destruction. This double identity reflects the ambivalence and ambiguity, which surrounded both geographic exploration and the army in the mid first century A.D. ${ }^{10}$

\footnotetext{
${ }^{7}$ For the Roman castra as a sort of mini-mobile city, which asserted Roman control and civilization see: Polyb. 6.31.10-12; 6.41.11; Cic. Prov. Cons. 34; and Hanel 2007, 395-397. On the concept of city versus countryside in Romanization, see: Woolf 1998, 50-53, 109-10; Wallace-Hadrill 2008, 169-173 \& 196-209.

${ }^{8}$ For the civilizing influence and imperial power of the mensor, see: Cuomo 2000, 192-195. For confusion over the identity of the metatores, see: Sherk 1969, 552. The level of confusion he expresses is not helped by the fact that the Christian Church seems to have adopted the term metator for administrative and pedagogical purposes of quite a different order. Compare: Cypr. Epist. 6.4; Ambros. Hexaem. 5.10.29; August. Serm. 289.3; Just. Cod. 12.40.5, 12.40.9; Lact. Inst. 4.11.11; with Hyg. De Mun. Cast. 40, 46 and Veg. Mil. 2.7.6, 2.7.9 \& 3.8.6. As the author cannot find a satisfactory connection between the military and Christian uses of the term, the latter group of texts will not be considered in this study. For full references, see: TLL 8.878-879.

${ }^{9}$ Romm 1992, 164.

${ }^{10}$ Romm 1992, 164-167.
} 
Two documents from the Imperial period that describe the Roman army in considerable detail provide additional critical evidence for the metatores. The first of these documents is the account of the Jewish rebellion written by Josephus.

Vespasian, eager to invade Galilee himself, set out from Ptolemais after drawing up the army in the accustomed Roman marching order. He ordered the auxiliary lightly-armed troops and the archers to go in advance, so that they might both prevent any sudden attacks by the enemy and investigate woodlands that were suspicious on account of their suitability for an ambush. And next followed a body of heavily-armed Roman soldiers, both infantry and cavalry. After these troops marched ten men from each century carrying their own equipment and the implements for marking out the camp. And after these came the engineers who were to straighten bends in the road, level rough areas, and cut down woodland which was blocking the way, so that the army would not be exhausted by a difficult march. ${ }^{11}$

Josephus, writing this description of the Roman army in his history of the Jewish War of A.D. 66-71, does not expressly name the troops carrying the equipment for laying out the camp as metatores. It is quite possible that not all the men described as 'marching in advance' were actually employed as metatores for the purpose of laying out the camp. However, a further passage from the same work reinforces the image of the men carrying the equipment for marking out the camp, and suggests that they not only carried the tools, but that they were all also responsible for its construction too.

Now as Titus was advancing on the enemy's territory, the officers sent by the kings led the way with all the other allied forces; after whom came the engineers and those who were to measure out the military camp. After these came the commanding officer's baggage and Titus himself with the legionary infantry assigned to the baggage-train and a select body of troops. Next came the pike men and the legionary cavalry. ${ }^{12}$

When both passages are taken together, a number of interesting facts about the Roman army appear. First, the Roman column of march had a number of general tendencies it followed

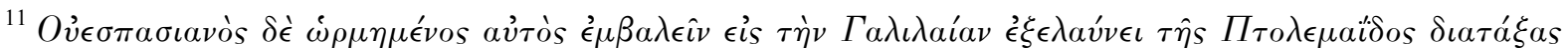

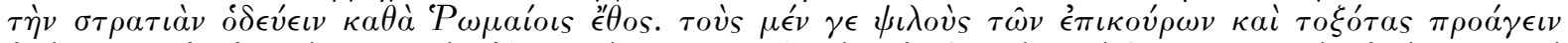

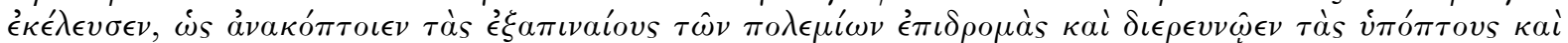

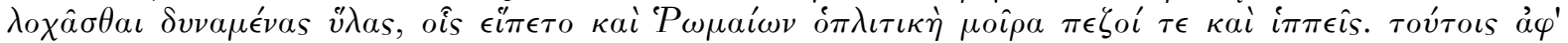

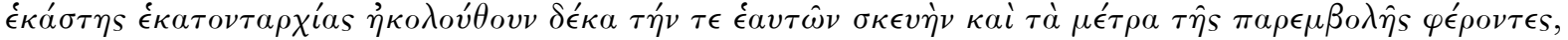

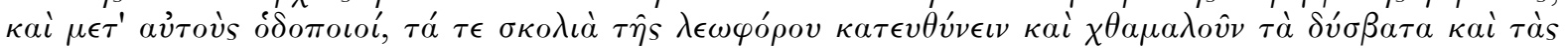

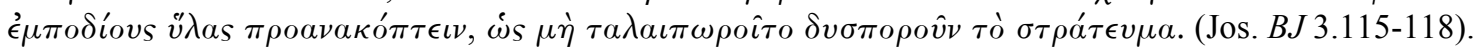

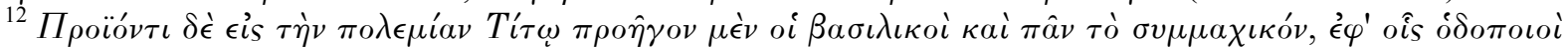

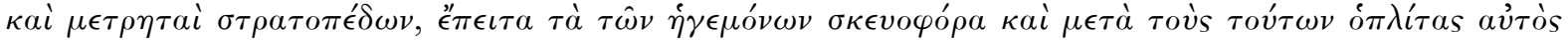

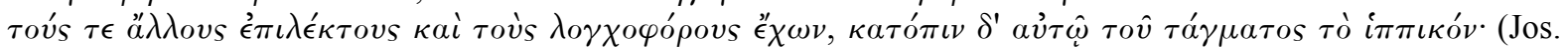
BJ 5.47). 
when forming up to march, but was not bound to an absolute formula. One of the general tendencies seems to have been the deployment of an advance scout detachment composed of auxiliary cavalry and infantry. Evidence gleamed from other sources indicates that this advanced group was composed of two parts, the procursatores or advanced guard and the exploratores or long-range advanced scouts. ${ }^{13}$ These two groups seem to have always been followed by a group of men who were tasked with camp construction and road repair. As a consequence of their marching directly behind both the procursatores and exploratores, the camp builders probably relied on these two groups of advanced troops for guidance through the landscape and assistance in selecting a campsite. ${ }^{14}$ Another tendency to be considered more fully in Chapter Three is the position of the over-all military commander and his baggage in the line of march. In both passages these elements form part of the forward section of the Roman column, suggesting that the camp was probably constructed around the Praetoriun in general and the commander's tent in particular.

From the two passages of Josephus cited here, it seems clear that the men responsible for building the camp were distinct and different from the hodopoioi or engineers who dealt with road maintenance. ${ }^{15}$ This suggests a high degree of specialization and differentiation in the assignment of construction tasks within the Roman army. Josephus interestingly enough, however, does not specifically name the men who built the camp as metatores. This is rather unusual both for the Roman army which tended to have a name for everything, and for a Greek author who was for the most part very knowledgeable about the Roman army and the Greek technical vocabulary which applied to it. It may have been that Greek did not have a specific term for individuals assigned to construct a camp, and, being culturally proud, Greek authors were reluctant to borrow the Latin term of metator for use in their writings. The absence of a Greek term for a function or occupation such as metator is indicated by the few descriptions of camp layout found in early Hellenistic literature. The only Greeks who seem to have had a specific system for camp construction in this literature were the Spartans. And from the literary descriptions it would seem that their system depended more on each soldier knowing their place in a circle around the king rather than on the use of any sort of a grid

\footnotetext{
${ }^{13}$ For a full discussion of these troops, see: Austin 1995, 39-54.

${ }^{14}$ For the involvement of exploratores in the selection of a campsite, see: Caes. $B G$ 1.21.1, where two centurions lead a group of exploratores forward to pick out a camping site. For centurions as the normal leaders of independent groups of exploratores, see: P. Brit. Muse. 2851. A discussion of this document can be found in Fink 1971, Doc. No. 63.

${ }^{15}$ This distinction is indicated by the strong use of kai met' autous in Jos. BJ 3.118, which both separates the two groups of troops even as it joins them together.
} 
which required special technicians. It is doubtless in the light of this that Polybius remarked that the Greeks were lazy by adapting their camps to fit the landscape while the Romans take the trouble to alter the landscape by entrenching. ${ }^{16}$ If Greek did indeed lack a word for metator, then the best the Greek authors could do was to describe the soldiers who built the Roman castra as metrêtai stratopedôn or measurers of the camp. However, this description matches that of the metatores provided by Vegetius, Frontinus, and Lucan. Because of this, it seems reasonable to assign the label of metatores to the troops whom Josephus describes as bearing equipment for the camp.

If such identification is correct, then it would seem that there were six hundred metatores in each legion, ten from each century. ${ }^{17}$ This indicates that each contubernia or infantry squad of eight supplied a metator. ${ }^{18}$ This in turn suggests that each metator was responsible for laying out and setting up the individual camping area for his own contubernia within the castra.

The concept of the metator setting up the individual living areas within the castra is probably in accord with the other specific evidence on the post provided by the anonymous $D e$ Munitionibus Castrorum, even though this work consistently refers to the metatores in the context of the cohort rather than the century. The reason for this seems to have been because the author of this work was primarily interested in describing the ways in which large-scale military forces could be housed while on the march. His remarks moreover suggest that the Roman army tended to deploy for combat operations and small scale actions at the level of the cohort or numeru; a subdivision of the cohort which was of irregular size and which could be composed of troops from different units. ${ }^{19}$ However, while the legion, cohort, and ala or cavalry wing were the administrative and battle-field units of concern to the Roman aristocratic commanders and authors, a considerable body of evidence from papyri and wooden writing tablets suggests that the century, terma, and contubernia were far more

\footnotetext{
${ }^{16}$ See: Xen. Const. Lac. 12.1-4; Xen. Cyr. 3.3.23-27, 8.5.8-14; Polyb. 6.42.1-5. It is also perhaps significant that camp construction is one subject omitted from the otherwise comprehensive introductory article on Greek military science in the Oxford Handbook of Engineering and Technology in the Classical World. See: De Souza 2008. 673-690.

${ }^{17}$ For the number of men in a legion and the equivalent number of centuries see: Campbell, 1994, 20-21, 28-29, 34; and more recently, Gilliver 2007, 189-197.

${ }^{18}$ On the size of a contubernia see: Breeze 1969, 50-55; Breeze 1974, 2, 1, 435-451; Frere 1980, 51-60. It is interesting that Breeze 1974 does not mention the metator as a part of the Roman army.

${ }^{19}$ See: Hyg. De Mun. Cast. 24. This is supported by Arr. Per. 6.1, 9.3, Arr. Ect. Con. Alan. 1-11, and by BGU 2492 = Campbell 1994, Doc. No. 149. For a comprehensive but problematic discussion of the numeri, see: Southern 1989, 81-117, particularly 81-9.
} 
important to enlisted soldiers operating on a day to day basis. ${ }^{20}$ As a consequence, the mention of a post in the context of a cohort does not preclude or exclude the possibility that the post mainly existed and functioned at the level of the century, terma, or contubernia. All three of the units were part of the larger cohorts and cavalry wings. One could speak of a metator conducting operations for a cohort in the same way that modern commentators speak of individual communications technicians or riflemen conducting operations for a given brigade or division. Both of these modern military occupations exist at the level of a squad, but squads are part of a brigade the same way that a contubernium was part of a cohort.

The De Munitionibus Castrorum, wrongly attributed to the agrimensor Hyginus Gromaticus, provides a wealth of information on the establishment of the castra and the internal command structure of the Roman Legion. It specifically mentions the presence of the metatores in two places, and implies their existence in two others. In one of the two specific references the metatores are explicitly named as being responsible for quartering their individual units within the rampart of the castra.

We have therefore explained the units' own ground plans and posted the entire army to their own positions; we have also shown which troops should be rearranged if it should be necessary. But if the cavalry wings were deployed in the rear camping area and the infantry or mounted cohorts in the forward area without any compelling necessity, it is, without doubt, a mark of the metatores' inexperience. $^{21}$

In another passage of the De Munitionibus Castrorum, the author explains that individual cohorts were responsible for laying out their own individual camping areas. As the opening sections of the De Munitionibus show, the individual camping areas were without doubt constructed around the century, terma, and the individual contubernia contained in those units. $^{22}$

Also, in the rear camping area, the units with five hundred men who are accustomed to encamp whether more tightly or loosely along the lanes, should

\footnotetext{
${ }^{20}$ See: $C P L .102=$ Campbell 1994, Doc. No. 1; P. Oxy. $1022=$ Fink, Doc. No. $87=$ Campbell, 1994, Doc. No. 9; SP. 368 = Fink, Doc. No. 74 = Campbell 1994, Doc. No. 11; Vind. Tab. Nos. 127, 128, 129, 137, 154, 160, 166, 168, 171, 180, 181, 184, 310, 311, 316, 319, 343, 346, 349.

${ }^{21}$ Exposuimus itaque suas species et universum exercitum suis locis constituimus; ostendimus etiam, si necessum fuerit, quis numerus commutari debeat. Quodsi alae in retentura positae fuerint et pedites $<$ in $>$ praetentura sive cohortes equitatae nulla necessitate cogente, sine dubio metatoris imperitiae signum est. (Hyg. De Mun. Cast. 46).

${ }^{22}$ Hyg. De Mun. Cast. 1, 4, 7, 16.
} 
construct a camp site wider than the lanes which will run into that self same allotted area since it often happens that the ranks are rearranged. ${ }^{23}$

A third passage mentioning the metatores reinforces the feeling that each unit operated with its own metatores, and that it was the metatores who were responsible for rearranging the ranks of the encamped units. In addition, from this passage, it would seem that the metatores were also responsible for restructuring the layout of the castra when it proved necessary.

Now, if the metator accepts a thousand men above the collated total, we will act as follows so that a place may be assigned to them in the same allotted area. ${ }^{24}$

Finally, the author states that not only were the individual cohorts and their sub-units responsible for laying out the individual camping areas within the castra, but that they were responsible for constructing the area of the rampart nearest to their camping site.

It is essential that the corners of a camp be rounded because they form 'hips' and these reduce the work in guarding against an assault. They will have to be curved out from the corner of the cohorts who produce the work's widths of 60 feet, all the way around in a line so that they embrace the outer walls, which makes a quarter circle. $^{25}$

Since the author of the De Munitionibus Castrorum makes it clear that many of the units on the rampart could be drawn from the auxiliary cohorts, it seems quite likely that the metatores existed both in legionary and non legionary units. ${ }^{26}$ Because of this, the section of the Roman marching column containing metatores which was described by Josephus may have contained more than the six hundred metatores of the legion. The final total number would be dependent on the number of legions and by the number or role of the non-legionary forces. The De Munitionibus Castrorum was written probably in the mid-second century A.D. or later, and enables us to postulate the presence of the metatores in the auxiliary cohorts of

\footnotetext{
${ }^{23}$ Et in retentura qui solent et quinquagenis hominibus per strigas strictius seu laxius tendere, quoniam saepe numeros evenit commutari, tensuram amplius efficiant quam strigae in eandem pedaturam incurrent. (Hyg. De Mun. Cast. 40).

${ }^{24}$ Nunc si metator mille homines super numerum compositum <acceperit, ut> in eadem pedatura locus adsignetur, sic faciemus. (Hyg. De Mun. Cast. 37).

${ }^{25}$ Angulos castrorum circinari oportet quia coxas efficient instabiliuntque opus propugnationem tutans. Circinari debebunt ex angulo cohortium quae efficiunt latitudines operis pedum LX usque quo linea exteriores comprehenderit, quae efficiunt partem quartam. (Hyg. De Mun. Cast. 54).

${ }^{26}$ See: Hyg. De Mun. Cast. 2, 24, 25, 40, 41.
} 
the later empire. ${ }^{27}$ However, they may not have been present in the cohorts of an earlier date. This is underlined by the fact that the nationes or allied troops described in the De Munitionibus do not seem to have had the structure, numerical composition, or technical occupations of their Legionary counterparts. ${ }^{28}$ Because of this it is likely that metatores from either the legion or the auxiliary cohorts had to lay out the camping areas of the nationes. The same may have been true for the cavalry alae; however, a dearth of evidence on the metatores makes it impossible to be sure.

\section{THE MENSORES}

Many scholars in considering the metatores have either been unable to establish a sound identity for them, or else have considered them to be identical to the mensores. ${ }^{29}$ Such an interpretation comes from a reading of two passages from the work on Roman military science written by Vegetius.

The metatores are those men who marching in advance select a location for the camp (castra). Beneficarii are so called from the fact that they are promoted through the indulgence of the tribunes. The book-keepers (librarii) are so called from the fact that they enter accounts pertaining to the soldiers in the account books. The tuba player, trumpeter, and bugler are those men who are accustomed to sound the battle call either on the straight horn, the brass horn, or on the bugle. The armaturae duplares are those men who get a double ration of grain, while the simplares are those men who get a single ration. Mensores are those men who in accordance with the pre-designated plan lay out the space in the camp (castra) in which the soldiers pitch their tents, or else in the cities provide lodging. ${ }^{30}$

For these reasons, provision should be carefully and zealously made that you establish the camp whether square, round, triangular or oblong in accord with the

\footnotetext{
${ }^{27}$ Lenoir 1979 in section 144 of his commentary dates the De Munitionibus Castrorum to the reign of Trajan on the bases of internal evidence that is principally dependent on the nature of the military units described within the text. However, the syntactical structure of the language of the De Munitionibus Castrorum seems to me to have more in common with Apuleius than with Suetonius or Tacitus. And since later Latin authors almost invariably drew on earlier work for both information and literary models, it does not seem safe to assign a narrow Trajanic date to this work. The best that can probably be said is that it was written between the end of the Dacian Wars in 112 and the accession of Septimius Severus in 193.

28 See: Hyg. De Mun. Cast. 30.

${ }^{29}$ For example see: TLL 1.1428, 8.753-754 \& 8.878-879. Also reference: Lenoir 1979, 116, section 127.

${ }^{30}$ Metatores qui praecedentes locum eligunt castris. Beneficiarii ab eo appellati, quod promouentur beneficio tribunorum. Librarii ab eo, quod in libros referunt rationes ad milites pertinentes. Tubicines cornicines et bucinatores qui tuba uel aere curuo uel bucina committere proelium solent. Armaturae duplares qui binas consecuntur annonas, simplares qui singulas. Mensores qui in castris ad podismum demetiuntur loca, in quibus tentoria milites figant, uel hospitia in ciuitatibus praestant. (Veg. Mil. 2.7.6-9).
} 
needs of the location so that the shape is not prejudicial to the utility, even though those camps which are credited as being the more beautiful are those to which a third section of length is added to the area of their width. Thus, one should issue instructions that the measurements should be calculated by the agrimensores in accordance with the pre-designated ground-plan, so that the army is contained to the allotted quantity. ${ }^{31}$

Reading these two passages against those mentioning the metatores, it is easy to see how the mensores or agrimensores (Vegetius uses the words interchangeably) might be considered one and the same. Nevertheless, there are a number of factors which suggest that the two were distinctly different though related occupations. To begin with, the description of the metatores is separated from that describing the mensores by a seemingly random list of types of soldier, which has no apparent logical order. Such separation would tend to suggest a separate identity for the two occupations described. In addition, Vegetius while clearly drawing his information from earlier military manuals, was describing the Roman army as he thought it should have been at the start of the fifth century A.D. As a consequence, the conditions found in the text of Vegetius cannot be assigned to an exact period, and may not have been true at the time when the De Munitionibus Castrorum was composed. Finally, the text of the De Munitionibus Castrorum contains references to two groups of people who seem to have been involved with camp construction and which were clearly distinct from one another.

The metatores, as has already been discussed, seem to have been responsible for establishing individual encampment areas for their respective units. Whenever the author of the De Munitionibus Castrorum refers to such operations, he referred to the metatores using a collective singular. ${ }^{32}$ At the same time there seem to be references to another group of men who were involved in camp construction and who were referred to in the plural as gromatici.

In the entranceway to the middle section of the Praetorian is the spot called 'The Place of the surveyor's cross,' (locus gromae), either because a crowd congregates at that spot or else because, in accord with the established rule for taking measurements, the surveying cross (groma) is set up at the top of an iron pole (ferramentum) on the very same spot so that the gates of the camp make a star in

\footnotetext{
${ }^{31}$ Quibus caute studioseque prouisis, pro necessitate loci uel quadrata uel rotunda uel trigona uel oblonga castra constitues, nec utilitati praeiudicat forma, tamen pulchriora creduntur quibus ultra latitudinis spatium tertia pars longitudinis additur. Ita autem ab agrimensoribus podismum mensurae colligi oportet, ut ad quantitatem concludatur exercitus. (Veg. Mil. 3.8.3-4).

${ }^{32}$ On the collective singular, see: Kennedy 1941, 118, n.199.2.
} 
accord with the sighting lines. And the masters of this art are specifically called land surveyors (gromatici) for the reason explained above. ${ }^{33}$

Now I have developed with intense concentration a method of surveying researched by myself, relating to the total number of legions, which pertains to the deployed legions and the separate units and which demonstrates the difficulties for professionals (periti) concerning this arrangement, so that if you judge that it is worthy to be applied, I might be the first to bring a surveying novelty to your greatness, which I hope will please you if you will first undertake a conventional survey. $^{34}$

The term gromatici does not really appear elsewhere in Latin literature, but the presence of the word with professores and the singular nature of metator in this text show that the periti of the second passage were the gromatici. The identification of the gromatici with the mensores or agrimensores is more problematic, however. The text provides three clues to such identification. First there is the fact that the gromatici were described as professores in the art of using the groma. The term professor does not occur anywhere else in association with surveying, but there are numerous places in the Corpus Agrimensorum where authors who were clearly active agrimensores refer to nostrae artis, nostri operis or nostri studiosi, which tend to be translated as 'our profession or our professional skill. ${ }^{35}$ Given this, the skill or ars referred to in the De Munitionibus Castrorum may be taken as referring to the agrimensores' professional skill.

Second, the groma or ferramentum as the tool was often called seems to have been an unofficial symbol of the mensores. ${ }^{36}$ The association of the gromatici with this instrument thus strengthens identification with that group.

\footnotetext{
${ }^{33}$ In introitu praetorii partis mediae ad viam principalem gromae locus appellatur quod turba ibi congruat sive in dictatione metationis posito eodem loco ferramento groma superponatur, ut portae castrorum in conspectu rigoris stellam efficiant. Et professores eius artis causa supra scripta gromatici sunt cognominati. (Hyg. De Mun. Cast. 12).

${ }^{34}$ Nam quod ad legiones dispositas et dividuos numeros pertinet, quod et peritis compositione difficultates ostendet, methodum metationis a me exquisitam, ad numerum legionum pertinentem intento ingenio elaboravi, ut, si dignatus fueris iniungere, novitatem metationis ad magnitudinem tuam primus adferam, quae tibi, spero, placebit si primum cottidianam metationem tractabis. (Hyg. De Mun. Cast. 47).

${ }^{35}$ See for example: Front. De Art. Men. 12.1; Balb. Ad Cels. 204.1; Hyg. De Gen. Contra. 96.5.

${ }^{36}$ See: Figs. $1 \& 2$ for reconstructions of the groma. For an example of a groma as a symbol of a mensor, see: CIL 6.6786. The groma appears at the bottom of the stela with a number of other tools. The top of the stone is surmounted by a relief sculpture of military arms, which might be mistaken as a mark of service in the army. However, the mensor in question was a freedman who could not have served in the army. Thus the sculpture likely represents bravery which was one of the three virtues revered or associated with the mensores and which was personified as a woman on the monument of Nonius Datus. The three virtues were patientia, virtus, and spes. The military standards would certainly represent virtus, and it is quite possible that the groma could have represented spes depending on how one interprets the term. For the monument of Nonius Datus see: CIL 8.2728
} 
Third, and perhaps most important, is the name gromaticus itself. The name translates as one skilled in the use of the groma. Most scholars consider the term to have been a late extrapolation used as a substitution for agrimensor. ${ }^{37}$ However, epigraphic evidence, dated to the late first or early second century A.D., indicates that the name gromatici may have been a shortened form of mensor gromaticus. ${ }^{38}$ If this is correct, then it seems likely that the title came into being in the Julio-Claudian or perhaps the Flavian period. This evidence will be considered more fully below in an examination of the different variations on the mensores and their role in the Roman army.

The social and technical role of the mensores, unlike the metatores, seems to be much better illustrated in documents that do not directly describe the Roman army. In an oft-quoted passage from the Res Rustica, Varro invoked the identity of the mensores in his exposition on the system of centuriation used to divide up agricultural land.

A iugerum should contain two actus quadrati. The actus quadrati are 120 feet in width and the same again in length: the measure is called an acnua in plain Latin. The smallest part of a iugerum is called the scripulum. It is a quadrilateral ten feet in length and width. From this principle, the mensores often state that a twelfth part or a sixth part of a field is left over or some other amount when they come to the iugerum, because the iugerum contains 288 scripula - the same value as the as was worth in ancient times, before the Punic war. ${ }^{39}$

This passage places the mensores squarely into an agricultural context by suggesting that it was the mensores who were responsible for dividing up agricultural land. However, while such a context might at first sight seem far removed from that of the Roman army to a

$=A E 1941.117$ and the discussion below. For discussion on the points raised see: Zimmer 2007, 93-95; and Grewe 2008, 329-333.

${ }^{37}$ See: Cassiod. Var. 3.52.2; Hyg. De Mun. Cast. 12; TLL. 6.2335; and Lenoir 1979, Introduction p. VIII.

${ }^{38}$ As noted, gromaticus means one who is skilled with the groma. There are inscriptions also noting a group of men as libratores, men who were skilled in the use of the libra; an instrument used for measuring elevation. In at least one of these inscriptions, the abbreviation for librator was preceded by an abbreviation, which can be extrapolated as mensor. Given such a connection it seems likely that gromaticus may have been formally preceded by mensor too. The term could have been and probably was dropped in common conversation much as it seems to have been on the inscriptions of several libratores. See: $C I L 6.2754 ; 8.2728=A E 1941.117 ; A E$ 1942/43.93; and n.86 \& 88 below. For an up-to-date discussion on the groma as an instrument for surveying in the horizontal and the libra as an instrument for surveying the vertical, see: Lewis 2001, 109-132.

${ }^{39}$ Ingerum, quod quadratos duos actus habeat. actus quadratus, qui et latus est pedes cxx et longus totidem: is modus acnua latine appellatur. iugeri pars minima dicitur scripulum, id est decem pedes et longitudine et latitudine quadratum. ab hoc principio mensores non numquam dicunt in subsicivum esse unciam agri aut sextantem, si $<_{c}>$ quid aliud, cum ad iugerum pervenerunt, quod habet iugerum scripula cclxxxviii, quantum as antique noster ante bellum punicum pendebat. (Varr. RR 1.10.2). 
modern viewer, it was in point of fact an automatic association for Varro and his audience. As William Braudhead pointed out in his recent article on colonial land distribution, the Roman colonia (the principal stage for the system of centuriation described by Varro) was an extension of Roman military control. Each colonia regardless of its legal status was intended as a garrison to secure conquered territory in Italy. Even when the colonia lost this function and became a political instrument for the Roman nobiles, the colonia continued to retain aspects of its military association since it was the discharged veterans of the Roman army who principally benefited from the distribution of land. ${ }^{40}$

In spite of this indirect connection to the Roman army, it seems clear that for most people in antiquity, the main function of the mensores was the adjudication of boundary disputes and the regulation of land. It is this duty and its related tasks that occupy nearly all the texts gathered in the Corpus Agrimensorum, as well as most of the inscriptions pertaining to the mensores. ${ }^{41}$ The most vivid expression of the association between the mensores and land adjudication though comes from late antiquity.

However, a legal dispute that has come up about boundaries is entrusted to an agrimensor, so that wanton controversy may be dismissed. He is a judge, at any rate, of his own art; empty fields are his law-court. You might believe him to be some sort of a mad man, should you have caught sight of him wandering tortuous pathways. Accordingly, he searches for evidence through thickets and wild woods, nor does he walk in the common manner. The path for him is a matter of his own choosing, he demonstrates what he means, he proves what he has learned, he discerns the justice of the dispute with his own footsteps, and in the fashion of a mighty river, takes vacant areas from some and grants farmland to others. ${ }^{42}$

While this passage from the writings of Cassiodorus might reflect an exaggerated view of the mensores' importance, there can be little doubt as to their social role in the eyes of the author

\footnotetext{
${ }^{40}$ See: Braudhead 2007, 157-162. In this respect, also see: Keaveney 2007, 58-67.

${ }^{41}$ See: Dilke 1996, 76-96. For an up-to-date discussion on the social, political, and technical aspects of settling boundary disputes, see: Cuomo 2007, 103-130. The text of the Corpus Agrimensorum can be found in: Campbell 2000. A complete collection of the epigraphic documents pertaining to boundary disputes with ample commentary can be found in: Elliott 2004. It is interesting to note that Cuomo at the time of writing her book seems to have been completely unaware of Elliott's comprehensive but unwieldy dissertation.

${ }^{42}$ Agrimensori vero finium lis orta committitur, ut contentionum protervitas abscidatur. iudex est utique artis suae, forum ipsius agri deserti sunt: fanaticum credis, quem tortuosis semitibus ambulare conspexeris. indicia siquidem rerum inter silvas asperas et dumeta perquirit, non ambulat iure communi, via illi est lectio sua, ostendit quod dicit, probat quod didicit, gressibus suis concertantium iura discernit et more vastissimi fluminis aliis spatia tollit, aliis rura concedit. (Cassiod. Var. 3.52.8).
} 
and his contemporaries. ${ }^{43}$ For Cassiodorus the agrimensor was an important legal official whose knowledge and abilities set him apart from the rest of society. The exact social provenance of these formidable individuals is first attested in our surviving sources by a passage of Columella.

To which I answered that it was not the task of a farmer but of a mensor, especially since not even the architects for whom it is necessary to understand the principles of measurement deign to calculate the area of the finished buildings which they themselves have designed. Instead they consider the first task to be appropriate for their profession, but that the other belongs to those who measure out what has already been built and after making their calculation compute the measurement of the completed work. ${ }^{44}$

Here Columella equates the work of the mensores with that of the architects. This suggests that the mensores came from the better-educated members of the plebs, distinguishing them from the Republican finitores. As has already been established elsewhere, the finitores were equestrian officials appointed for a short term period as part of the Roman Republican land commissions. ${ }^{45}$ As such, they were involved with the division of land, but do not seem to have been involved with the adjudication of disputes over land. In respect to their related duties or functions, the finitores and mensores do seem to have one other commonality: neither seems to have been paid for their services. ${ }^{46}$ The finitores probably received an ex gratia payment from their senatorial superiors on the land commission, but at least in the early days of their existence, mensores were socially barred from directly charging fees for their work. This seems to have changed by the mid second century A.D., but if they could not charge fees for their services the office of mensor would have entailed some sort of

\footnotetext{
${ }^{43}$ The importance Cassiodorus attached to the mensores, their technical skill, and their relationship to the empire comes out in several passages of his work. Cassiodorus as an important administrative official in Ostrogothic Italy would have been well placed to evaluate the importance and the impact of such an office on ordinary people. His extensive interest in technical matters also suggests that he should probably be regarded as a reliable witness. See: Cassiod. Var. 3.52.3-8; Inst. 2.6.1.

${ }^{44}$ Quod ego non agricolae sed mensoris officium esse dicebam; cum praesertim ne architecti quidem, quibus necesse est mansurarum nosse rationem, dignentur consummatorum aedificiorum, quae ipsi disposuerint, modum comprehendere, sed aliud existiment professioni suae convenire, aliud eorum, qui iam exstructa metiuntur, et imposito calculo perfecti operis rationem computant. (Col. RR. 5.1). The mensor described here was probably the mensor aedificius who seems to have been involved in surveying buildings and public works. For an example of this occupation, see: $C I L 6.1975$ and n.48 within this chapter.

${ }^{45}$ Nicolet 1970, 99-103; Classen 1994, 161-70; Gargola 1995, 91-92, 183-185, 205, 221-222, 249-250; and Chapter One of this study.

${ }^{46}$ Cic. De Leg. Agr. 2.32; Ulp. Dig. 11.6.1.1-2; 11.6.7.3-4. The evidence regarding payment for the services of a mensor was quoted by Ulpian, in the context of explaining when and why it was appropriate for a praetor to grant an action in factu against a member of that profession. He says that one cannot sue a surveyor (mensor) as he will normally receive an honorarium, rather than a fee. The exception is for cases of deliberate fraud. See: Just. Dig. 11.6.1-5.
} 
independent source of funding. ${ }^{47}$ This suggests that the mensores either came from the ranks of the well-to-do plebs who lacked the property and connections to join the equites or else they were the freedmen and / or slaves of wealthy Romans who could afford to patronize their work. This supposition is to a limited extent supported by the evidence of epigraphy.

To the sacred spirits of the departed. Dydimus, slave of Augustus, land surveyor (mensor Agrarius) pious, lived 46 years rests here. His wife Julia Priminia set this up for him. 48

Lucius Aebutus Faustus, Freedman of Lucius (Aebutus) from the Claudian Tribe, surveyor (mensor), member of the Board of Six, set up this monument while still alive for himself, for his wife Arria Aucta, freedwoman of Quintus (Arrius), their children, and for the freedwoman Zepyra. ${ }^{49}$

Behold gentle Aper you lie here; neither an enraged maiden nor fierce Meleager pierced you through the vitals with a sword. Silent death crept upon you suddenly and caused your fall who stole away youthful beauty from you as you were blooming. To Titus Statilius Aper of the Voltinian tribe, a surveyor of public works. He lived 22 years, 8 months, and 15 days. Titus Statilius Proculus of the Voltinian tribe and Argentaria Eutichia his parents set this up for he who was their finest son and for Acivia Anthidis his wife, and his children, and his freedmen, his freedmen's children and their posterity. ${ }^{50}$

All three of the grave monuments here project a level of prosperity above that of the ordinary Roman citizen. The first two mensores clearly had wealthy patrons. The third, recording the premature death of the surveyor of public works Aper, was part of an elaborate grave stele found in Rome and which probably dates to the early second century A.D. ${ }^{51}$ Its impressive

\footnotetext{
${ }^{47}$ It may have been that mensores initially received an ex gratia payment too. However, there is no direct evidence for such a practice. Campbell thought that the profession of mensor started out as a sort of favour, which only gradually grew into a profession. Such an interpretation might suggest that mensores developed out of finitores, but the evidence of social status for the two groups is against it. See: Campbell 2000, introduction XLIX for more comments.

${ }^{48}$ DIIS MANIBUS/ SACR(is)/ DIDYMUS AVG(ustus) SER(vus)/ MENSOR AGRARIVS/ PIVS VIX(it) AN(nos) XLVI/ H(ic) S(itus) E(st)/ IVLIA PRIMINIA UXOR D(e) S(uo) F(ecit) (CIL. 8.12637).

${ }^{49}$ TRIB(u) CLAUDIA/ L(ucius) AEBUTIUS L(ucii) L(ibertus)/ FAUSTUS MENSOR/ VI VIR SIBI ET ARRIAE Q(uinti) L(ibertae) AUCTAE/ UXORI ET SUIS ET/ ZEPYRE LIBERT(ae)/ V(ivus) F(ecit). (CIL 5.6786). See: Zimmer 1982, 196-197 for bibliography and pictures. Also: Fig. 3. Also: Campbell 2000, XLVIII n.142 for further discussion.

${ }^{50}$ INNOCUUS APER ECCE IACES NON VIRGINIS IRA NEC MELEAGER/ ATROX PERFODIT VISCERA FERRO MORS TACITA OBREPSIT SUBITO FECITQ(ue)/ RUINAM QUAE TIBI CRESCENTI RAPUIT IUVENILE(m) FIGURAM. T(ito) STATILIO VOL(tinia tribu) APRO MENSORI/ AEDIFICIOR(um). VIXIT ANN(os) XXII M(enses) VIII D(ies) XV/ T(itus) STATILIUS VOL(tinia tribu) PROCULUS/ ACCENSUS VELATUS ET ARGENTARIA/ EUTYCHIA PARENTES FILIO OPTUMO ET/ ORCIVIAE ANTHIDI UXORI EIUS SIBIQ(ue) ET SUIS/ LIBERTIS LIBERTABUS POSTERISQUE EORUM. (CIL 6.1975). See: Zimmer 1982, 198-200 for bibliography and pictures; also see: fig. 4. See: Cuomo 2007, 93-95 for discussion of this inscription.

${ }^{51}$ Cuomo 2007, 93, n.65.
} 
relief sculptures of a boar, surveying instruments, and a full-figure image of Aper himself, clearly show an impressive level of independent prosperity. Since Aper died young, the family's wealth could not have come from Aper's profession. This indicates that while mensores were in all probability members of the plebs, they should be considered at the very top of that social order.

This prosperity coupled with a humble social identity may in part account for the somewhat negative picture of mensores Seneca projects in one of his epistles, though the passage has a strong rhetorical flavor too.

The geometres teaches me to measure my estates rather than teaching me in what way I should measure what is sufficient for a human life. He teaches me to count and adapts my fingers to greed rather than teaching that my computations do not pertain to anything, that one is not happier whose patrimony tires out the accountants, or rather that holding property is pointless for anyone who would be very unhappy if forced to reckon for himself how much he might have. How does it benefit me to know how to divide my land into parts if I do not know how to share it with my brother? What use is it to me to calculate exactly the square footage of a iugerum and to catch an error if also a piece escapes my measuring rod, if a rash neighbour swiping a piece from me upsets me? The geometres teaches me how not to lose anything from within my boundaries, but I myself prefer to learn how to cheerfully lose everything. "I am being driven from my paternal and ancestral farm" is the rejoinder. What? Who held this land before your grandfather? I'm not talking about what person, but can you indicate to what populace it belonged? You have come onto this land not as master, but as tenant. Whose tenant are you? If things go well for you, you will be a tenant of the heir. The lawyers state that 'no public property can be acquired by squatters' rights'. This land which you hold ... is in fact public and indeed belongs to the human race. $^{52}$

Seneca's purpose in this epistle was to establish the study of philosophy as the one true ars liberalis. ${ }^{53} \mathrm{He}$ did this by maligning each of the seven canonical branches of the artes

\footnotetext{
${ }^{52}$ Metiri me geometres docet latifundia potius quam doceat quomodo metiar quantum homini satis sit; numerare docet me et avaritiae commodat digitos potius quam doceat nihil ad rem pertinere istas conputationes, non esse feliciorem cuius patrimonium tabularios lassat, immo quam supervacua possideat qui infelicissimus futurus est si quantum habeat per se conputare cogetur. Quid mihi prodest scire agellum in partes dividere, si nescio cum fratre dividere? Quid prodest colligere subtiliter pedes iugeri et conprendere etiam si quid decempedam effugit, si tristem me facit vicinus inpotens et aliquid ex meo abradens? Docet quomodo nihil perdam ex finibus meis: at ego discere volo quomodo totos hilaris amittam. 'Paterno agro et avito' inquit 'expellor.' Quid? ante avum tuum quis istum agrum tenuit? cuius, non dico hominis, sed populi fuerit potes expedire? Non dominus isto, sed colonus intrasti. Cuius colonus es? si bene tecum agitur, heredis. Negant iurisconsulti quicquam usu capi publicum: hoc quod tenes, quod tuum dicis, publicum est et quidem generis humani. (Sen. Ep. 88.10-12). For an alternate translation with some interesting remarks on this passage, see: Cuomo 2007, 106-107.

${ }^{53}$ Sen. Ep. 88.1-2. For a fuller discussion of the artes liberales, see: Francese 2007, 44-46.
} 
liberales and demonstrated how that they provided practical knowledge which in no way made people philosophically free. ${ }^{54}$ Such an attack was almost certainly a rhetorical device intended to bolster Seneca's case, since as Brad Inwood has pointed out, Seneca demonstrated repeatedly through his writings a healthy respect for technical skill and scientific investigation into the natural world. ${ }^{55}$

Because of its strong rhetorical flavor, this passage should in no way be taken as reflecting day-to-day life. At the same time, the passage probably does show several general social trends which reflect the role of the surveyor in antiquity. First, Seneca used the Greek term geometres to refer simultaneously to one who taught mathematics and to one who surveyed land. Numerous inscriptions surviving from antiquity attest to the fact that Greek writers under the Roman Empire used the term geometres to refer to a mensor. ${ }^{56}$ Such a linguistic association simultaneously suggests some ambiguity in the efforts of Greek speakers to find a suitable term to equate with mensor. ${ }^{57}$

Aspects of the geometres' role seem to emerge from the Geography of Strabo. Written in the reign of Augustus, this work described the geography and physical environs of the Roman world as it was known to the political leaders and philosophers of the day. The second book of this monumental sixteen book work outlined the philosophic framework in which the Geography was written. In the course of this intellectual exposition, Strabo explained that:

Now as for the matters which he regards as fundamental principles of his science, the geographer must rely upon the geometricians (geometrai) who have measured the earth as a whole; and in their turn the geometricians (geometrai) must rely upon the astronomers; and again the astronomers upon the physicists. ... Now the astronomers first accept these principles, either in whole or in part, and then work out the subsequent problems, namely, the movements of the heavenly bodies, their revolutions, their eclipses, their sizes, their respective distances, and a host of other things. And, in the same way, the geometricians (geometrai), in measuring the earth as a whole, adhere to the doctrines of the physicists and the astronomers and, in their turn, the geographers adhere to those of the geometricians

\footnotetext{
${ }^{54}$ For the canonical list of the artes liberales as they were understood in late antiquity see: Isid. Etym. 1.3.1. It is interesting that Isidore associated the study of geometry automatically with the reckoning of land as it is described in the passage of Seneca cited above.

${ }^{55}$ Inwood 2005, 14, 16.

${ }^{56}$ See: Lewis 2001, 5-6; Cuomo 2007, 106-7, 114-120.

${ }^{57}$ For some indication of this ambiguous identity, see: Campbell 2000, XLVIII, n.141 where he mentions an inscription from Smyrna where a man of twenty two years is described as best in the law and surveying. For the inscription itself, see: Malay 1983, 283.
} 
(geometrai). ${ }^{58}$

Strabo in a later passage goes on:

By accepting these principles, then, and also by making use of the sun-dial and the other helps given him by the astronomer-by means of which are found, for the several inhabited localities, both the circles that are parallel to the equator and the circles that cut the former at right angles, the latter being drawn through the poles - the geometrician (geometres) can measure the inhabited portion of the earth by visiting it and the rest of the earth by his calculation of the intervals. In this way he can find the distance from the equator to the pole, which is a fourth part of the earth's largest circle; and when he has this distance, he multiplies it by four; and this is the circumference of the earth. Accordingly, just as the man who measures the earth gets his principles from the astronomer and the astronomer his from the physicist, so too the geographer must in the same way first take his point of departure from the man who has measured the earth as a whole, having confidence in him and in those in whom he, in his turn, had confidence, and then explain, in the first instance, our inhabited world - its size, shape, and character, and its relations to the earth as a whole; for this is the peculiar task of the geographer. $^{59}$

Both of these passages from Strabo's Geography show that the geometres was in some way involved in gathering geographic or cartographic information and measuring the Earth. Pliny the Elder in his Natural Histories also seems to have considered the mensores as being involved in the measurement of long distances across open country since he used the term mensor to describe the men who measured the distance covered by the army of Alexander the Great. ${ }^{60}$ Pliny was not explicit in his description of the mensores' exact duties in these passages, but in addition to measuring the distance covered, they may have been responsible for describing the landscape through which the army passed too. Such a task would be in

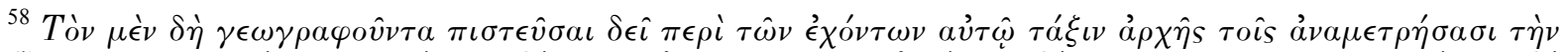

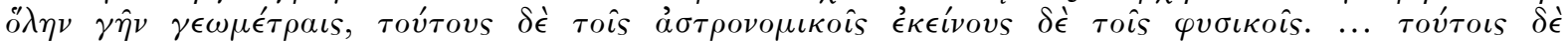

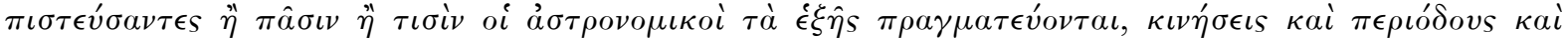

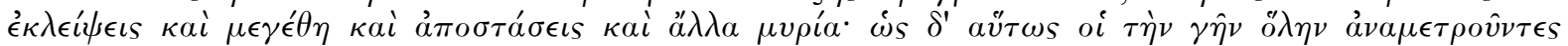

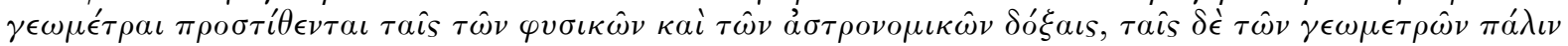
oi $\gamma \epsilon \omega \gamma \rho a ́$ q o . (Str. Geog. 2.5.2). My translation is adapted from that of the Loeb Classical Library.

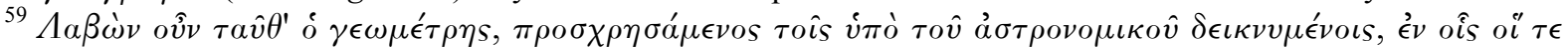

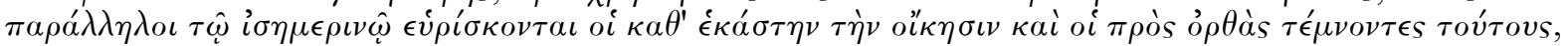

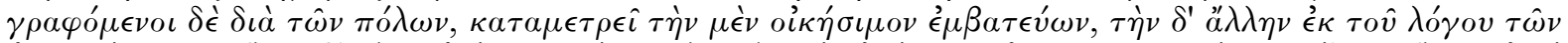

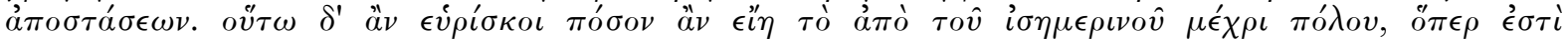

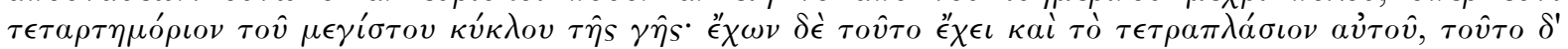

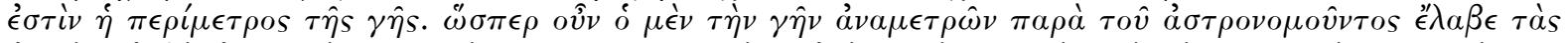

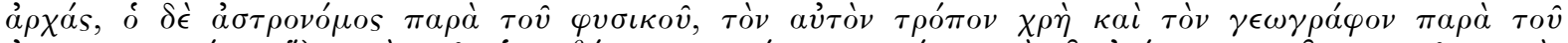

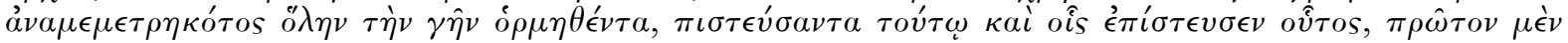

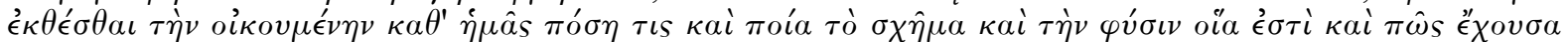

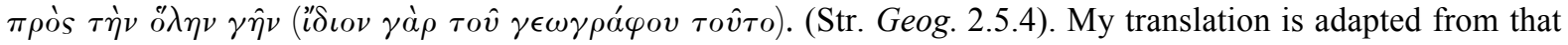
of the Loeb Classical Library.

${ }^{60}$ Plin. NH 6.91; 7.11.
} 
keeping with the function of the term in the texts of Censorinus and Martianus Cappella where mensor was used as a label to describe the activities of the geographer Eratosthenes. ${ }^{61}$

The extent to which mensores within the Roman army carried out geographic or cartographic work of this sort is unclear. However, the collective force of several additional passages from Pliny and Seneca suggests that they may have done so. The passages all relate to an expedition, which Nero sent out to explore the river Nile and the desert south of the Roman border in Egypt. ${ }^{62}$ According to Seneca, two centurions were responsible for the work:

In fact I heard two centurions (whom the emperor Nero, who was a lover of all virtues but in particular of the truth, had sent to investigate the origin of the Nile) telling how they undertook a long journey, when, after they were equipped with a band of helpers by the king of Ethiopia and given recommendations to the neighboring kings, they penetrated to the most distant areas. ${ }^{63}$

Pliny paints a slightly different picture of events by explaining that the expedition was headed by a tribune from the Praetorian Guard and consisted of an entire cohort of infantry.

Recently, some praetorian soldiers who were sent out with a tribune for the purpose of exploring Ethiopia reported to Nero, who was thinking of entering into a future conflict there, that it was empty. ${ }^{64}$

In another passage Pliny describes how: the members of the expedition drafted what seems to have been a map or diagram of the region.

A map (forma) of Ethiopia was examined when a report was made to Nero that showed nothing for 986 miles past the border of the empire at Syrene all the way to Merin where a rare grove of palm trees grew. ${ }^{65}$

The exact nature of the forma in this passage cannot be identified with any degree of certainty. However, whatever it was, it seems likely that some sort of surveyor would have been necessary for the collection of any sort of exact cartographic data. From the evidence of

\footnotetext{
${ }^{61}$ Censor. DN 15.2; Mart. Cap. 6.598.

${ }^{62}$ On this expedition, see: Sherk 1947, 540-541; and Nicolet 1991, 89-91.

${ }^{63}$ Ego quidem centuriones duos, quos Nero Caesar, ut aliarum uirtutum ita ueritatis in primis amantissimus, ad inuestigandum caput Nili miserat, audiui narrantes longum illos iter peregisse, cum a rege Aethiopiae instructi auxilio commendatique proximis regibus penetrassent ad ulteriorem. (Sen. QN 6.8.3).

${ }^{64}$ Certe solitudines nuper renutiavere principi Neroni missi ab eo milites praetoriani cum tribuno ad explorandum, inter reliqua bella et Aethiopicum cognanti. (Plin. NH 6.181.2).

${ }^{65}$ Cognita Aethiopiae forma ut diximus, nuper allata Neroni principi raram arborem Meroen usque a Syrene fine imperii per DCCCCLXXXXVI p. nullamque nisi palmarum generic esse docuit. (Plin. NH 12.19.1).
} 
Strabo, such an individual would have been a geometres and it is quite possible that the geometres may have been some sort of mensor.

The highly technical work which regional cartographic surveying would have entailed, is discussed in one and only one text in the Corpus Agrimensorum, that of Hyginus. ${ }^{66}$ This would suggest that while some mensores were capable of taking accurate geographic measurements and conducting cartographic work, perhaps not all mensores were capable of such complicated abstract mathematics. Yet, Robert Sherk in his 1974 article considered the production of military maps to have been one of the main duties of the mensores militum. ${ }^{67}$ His judgment came both from the texts of Pliny and Hyginus, and from an inscription mentioning a Chorographiarius:

For Tenatus Primio son of Lucius, Praetorian soldier, map-maker (chorographiarius) of the $3^{\text {rd }}$ Cohort, bronze engraver (caelator) in the same unit. His mother set this up for a most devoted son. ${ }^{68}$

In spite of Sherk's assertion that it is 'obvious' that chorographiarius stands for mensor, there is little evidence that the two occupations were constantly one and the same. ${ }^{69}$ It is true that the Corpus Agrimensorum frequently mentions the use of "maps" in the establishment of a survey, but it is important to understand that the types of maps to which the Corpus Agrimensorum was referring were very different from the maps produced by the chorographiarius. The terms used for map in the Corpus included podismus, aes, and forma ${ }^{70}$ As Richard J. A. Talbert pointed out in his recent article on Greek and Roman mapping, the term forma was an open-ended word which could refer to any visual element which could be shown to contain geometric shapes. ${ }^{71}$ Such items could include objects ranging from wall paintings to statuary, to maps, and in late antiquity even to water pipes. A

\footnotetext{
${ }^{66}$ Hyg. De Con. Lim. 144.15-148.30. For discussions on the methodology used for measuring the Earth, see: Lewis 2001, 143-156; supplemented by Geus 2004, 11-27. It is important to recognize that in their discussion of the astronomical methods used to reckon the size of the Earth, neither of these authors were able to take advantage of research on the Antikithera mechanism which has the potential to revolutionize our understanding of how the ancients may have gone about measuring time and space. For some thoughts about this device, see: Hannah 2009, 3, 28-31, 47.

${ }^{67}$ Sherk 1974, Vol. 2, 1, 558-560.

${ }^{68}$ [- T] enatio / L(uci) f(ilio) / [P] rimioni / [mi]liti praetor(iano) / c(o)hort(is) IIII / [ch]orographiar(io) / [ite]m caelatori / [fil]io piissimo mater ( $A E$ 1947.61)

${ }^{69}$ See: Sherk 1974, 550 for further discussion. For other examples of chorographiarii, see: IGRR. 1.1365; CIL. 8.12914. For other examples of caelatores see: CIL 2.2243; AE 1912.258; and AE 1969/70.36.

${ }^{70}$ See by way of example: Front. De Agr. Qual. 3.16; Front. De Art. Mens. 12.10, 14; Hyg. Lim. 76.9, 78.4-6; Hyg. De Con. Agr. 84.16-17, 88.12; Hyg. De Gen. Cont. 92.9; Hyg. Const. Lim. 134.5, 136.36, 154.18; Lib. Col. 174. For further discussion on these terms, see: Dilke 1985, 96, 100-8, 167, 177; and Campbell 2000, 397.

${ }^{71}$ Talbert 2008, 14.
} 
podismus by contrast, as can be seen from the use of the term in the second passage of Vegetius quoted above, clearly referred to a ground plan. Such ground plans seem to have included plans for a camp or building, plans of a city, and the maps of centuriated land attached to a community. ${ }^{72}$ The latter were commonly inscribed in bronze and set up in a public place. ${ }^{73}$ It is this practice that caused the mensores to use the term aes as a form of shorthand for podismus when referring to the plans of centuriated land. In essence a podismus or aes was any diagram which was dependent on the system of centuriation and which could have been depicted using a simple grid. Evidence that the mensores could and did produce such plans can be found in the depiction of plans found on the grave altar set up in memory of T. Statilius Aper. ${ }^{74}$

The evidence of Vitruvius and Ptolemy reveal the chorographia as something quite different. ${ }^{75}$ If their evidence can be trusted, then the chorographia was a depiction of a wide expanse of landscape containing mountains, rivers, forests, rivers, cities, and even large sections of ocean. The creation of such "maps" may have depended far more on the astronomical principles developed by Eratosthenes for the formation of sphragides or seals than on the principles of centuriation. ${ }^{76}$ According to Ptolemy, the chorographia and the work of the chorographiarius had much in common with landscape painting. ${ }^{77}$ This would suggest that the chorographus was in essence a combination of astronomical or mathematical elements and fine art. If this was true, then the chorographia would have had little in common with what modern cartographers call a map. Because of this, it may have been possible for some mensores to have produced a chorographia which would have made the mensor a chorographiarius, but there is nothing that proves that a chorographiarius was at all times a mensor. The best that can be said from the inscription cited by Sherk is that the Praetorian Guard at some point in its existence had people who were qualified to be chorographiarii and that emperors may have had detailed surveys and renderings of large

\footnotetext{
${ }^{72}$ For the concept of a plan for the Roman castra, see: Richardson 2004, 4-14; Dobson 2008, 68-72, 96-105, 120-121. For the plans of cities, see: Meneghini 2007, 205-218; Trimble 2008, 67-98; and Wallace-Hadrill 2008, 275-278 \& 301-313. The plans discussed are only for the city of Rome, but there is no reason to suppose that it was impossible for other cities to have similar plans on a more modest scale.

${ }^{73}$ On these bronze plans, see: Moatti 1993, 33-52; and Chouquer 2001, 48-60, 128-141, 171-173; and Talbert 2008, 9-10.

${ }^{74}$ On this altar see: CIL. 6.1975 and Zimmer 1982, 198-200. Plans such as those depicted on this altar were probably drafted on a perishable substance such as wood or papyrus. For a stimulating but by no means exhaustive discussion of graphics in ancient texts, see: Froschauer 2009, 9-22.

${ }^{75}$ Vitr. Arch. 8.2.5-6; Ptol. Geog. 1.1.

${ }^{76}$ The Sphragides were graphic representations of a regions of the Earth, which were drafted using pure geometry, astronomy, and topography. For discussion of this philosophical topic, see: Geus 2004, 14-26.

${ }^{77}$ See the notes and translation of Ptolemy in: Berggren 2000, 56-58.
} 
geographical regions commissioned for political or military purposes. ${ }^{78}$

The other jobs Sherk assigns to the mensores all more or less fall within the traditional skills and functions that might be expected from experts in centuriation, geometry, and land law. First Sherk suggests that the mensores were responsible for surveying the ground for Roman marching camps and permanent fortresses. ${ }^{79}$ Given the testimony of Vegetius and the De Munitionibus Castrorum cited above, this should probably be regarded as an established fact, though exactly when they started laying out the castra is a question which Sherk does not seem to have felt like considering. There is evidence which suggests that the mensor may have been introduced to the army in the second century B.C. ${ }^{80}$ At the same time, that evidence may indicate that the role of the mensores in the army of the Republic may have been somewhat different than it was under the Principate. The concept of the mensor as modern scholars understand it may have been due more to the activities of Caesar or Augustus than to the traditions of any Republican institution. There seems to be evidence to indicate that Caesar may have employed mensores during the course of the Gallic Wars and that he subsequently employed them for both military and non-military purposes. ${ }^{81}$

Next, Sherk argued that the mensores were responsible for surveying land attached to or controlled by the individual legions. ${ }^{82}$ His argument while logical does not rest on the solid foundation, which one could wish. It can be established beyond question that mensores in the Roman army were involved in the adjudication of boundary disputes between the legions and local landholders. ${ }^{83}$ Likewise, it is clear that the legions did indeed control and lease land to

\footnotetext{
${ }^{78}$ Austin and Rankov dismissed the idea that mensores could gather sufficient information for a map during an active campaigning season, but they did not consider Rome's archival abilities or the relationship, which may have existed between mensores and metatores. See: Austin and Rankov 1995, 99-104. For a discussion of the relationship between mensores and metatores, see below. The expedition, which may have produced a chorographia about which we know the most, was that of Nero to Ethiopia in A.D. 61. On this expedition, see: Sherk 1974, 540-541; and Nicolet 1991, 86, 89-91.

${ }^{79}$ Sherk 1974, 552-553.

${ }^{80}$ See: evidence provided by Lucil. Fr. 100, and Chapter Three below.

${ }^{81}$ The presence of mensores in Caesar's army depends on one's interpretation of Cicero's Philippics. Cicero, in these speeches, twice referred to one L. Decidius Saxa as metator. Depending on how one interprets the circumstances of Saxa's life, these references may reflect a deliberate slur on mensor which was intended as an insult to Saxa. The interpretation of the text is too involved a topic to be taken up here. For details, see: Caes. BC 1.62.2; Caes. BG 1.21.1; 2.17.1; 4.17.2-12; Cic. Ad Fam. 9.17.2; Cic. Clu. 161; Cic. Phil. 8.9; 8.26; 10.22; 11.12; 11.37; 12.20; 13.2; 13.27; 14.10; Liv. Epit. Fr.127; Dio 47.35.2; 47.35.4; 47.36.2-4; 48.24.2-8; 48.25.1-4; App. $B C$ 4.87; $A E$ 1990.186d; Syme 1937, 127-137; and Hinard 1985, 129, 153-64.

${ }^{82}$ Sherk 1974, 553-554.

${ }^{83}$ For the involvement of military mensores in boundary disputes, see: CIL 3.586; AE 1969/70.567; AE 1940.44; $A E$ 1956.10. For full coverage see: Campbell 2000, 454-467. For a case study, see: Cuomo 2007, 117-118,
} 
individual soldiers and communities adjacent to legionary fortresses as Sherk claimed. Furthermore, it can be established that the legions were involved in large scale surveying projects in places such as Africa and the Danubian provinces. ${ }^{84}$ However, the epigraphic evidence specifically stating that legionary mensores were responsible for centuriating land belonging to the legions would seem to be limited. As a consequence, imperial freedmen or slaves, acting on the Emperor's orders, may well have carried out the task. Thus, while the involvement of legionary mensores in the centuriation of legionary land would seem logical and indeed likely, it should not be assumed as a constant reality.

Sherk added two other main functions to the role of military mensores, the centuriation of ager coloniarum and the layout of roads. ${ }^{85}$ Sherk's argument for the first depends entirely on a single passage of Hyginus' work the De Condicionibus Agrorum. The author recounted how an evocatus who was skilled in the science of surveying laid out boundaries for a colonia in Pannonia. ${ }^{86}$ The passage proves beyond doubt that mensores militum were responsible for laying out coloniae at the beginning of the second century A.D. The passage does not prove that the practice remained constant through time, however. Roman society was for the most part conservative and resistant to radical change, so it is reasonable to assume that mensores militum established whatever coloniae came into being from the time of Trajan through the time of Alexander Severus.

Sherk's argument for the involvement of mensores in the construction of roads is the most solid of his conclusions, though strangely enough he fails to cite the most telling evidence out of the Corpus Agrimensorum. This consists of a passage in which the mensor Balbus described how he as a mensor in the service of an unnamed emperor was involved in the survey and layout of military roads. ${ }^{87}$ As the writings of Balbus provide the most vivid glimpse available into the life of a mensor in the service of the Roman army, this passage will receive individual attention presently. However, before concluding this section of the chapter

which is buttressed by further examples on 126-127. For what may be the earliest example of military mensores adjudicating a boundary dispute under imperial orders, see: Elliott 2004, Doc. No. 20.

${ }^{84}$ For examples see: CIL 8.22786; AE 1949.153; ILS 9375 = Campbell 1994, Doc. No. 205; Dilke 1971, 156158; and Campbell 2000, 454-467.

${ }^{85}$ Sherk 1974, 555-558.

${ }^{86}$ Hyg. De Cond. Agr. 88.10-27. An evocatus was a veteran reservist kept on beyond his normal time of service to carry out a specific function which was usually, but not always technical in nature. See: Campbell 2000, 364365 for discussion on this point and on the passage in question.

${ }^{87}$ Balb. Ad Cels. 204.19-23. See below for further references and comments. 
with an examination of Balbus, we should first reconsider Sherk's other conjectures regarding the mensores of the Roman army and their historical development.

Drawing on three inscriptions that can be dated to the mid third century A.D., Sherk argued that each legion contained a nominal eleven mensores. ${ }^{88}$ In 2000, Brian Campbell pointed out that this reconstruction should in no way be taken as a constant for all legions in the third century let alone any other period. ${ }^{89} \mathrm{He}$ argued that mensores were not common and that for most of the Empire's history, the average legion was lucky to have even one mensor. While his arguments seem in the main correct as regards the rarity of mensores in general, Campbell based his assertions on faulty evidence. He argued his entire case from the evidence provided by the monumental inscription of Nonius Datus. However, Datus was a librator, which may have been a specialised subset of the mensor that dealt with issues of elevation. Evidence for such a conclusion comes from a series of inscriptions that describe their various subjects as being mensores with qualifications. The most important of these is the funerary inscription of Marcus Troianus Marcellus.

Marcus Troianus Marcellus, son of Marcus, of the Augustan tribe of Luceres, soldier in the 10th Praetorian Cohort, in the Scipionic century, leveling surveyor (mensor librator), lived 25 years 9 months. He was a soldier for 5 years and 7 months. His friends Lucius Magius Adeianus and Gaius Julius Tiberinus took care of this monument. ${ }^{90}$

The fact that Marcellus' friends referred to him as mensor librator suggests that the term mensor should also be understood in the case of Datus. The inscriptions of T. Statilius Aper and Didymus that referred to mensores as an aedificius and agrarius respectively, and were cited above, drive this point home. ${ }^{91}$ For the most part, Roman soldiers seem to have simply styled themselves as mensor or in rare cases librator on their monuments. The fact that the De Munitionibus Castrorum referred to surveyors as gromatici suggests that the full titles of the various surveying posts within the army for most of the empire were mensor gromaticus

\footnotetext{
${ }^{88}$ AE 1904.72; CIL 3.8112; 8.2564; See: Sherk 1974, 547-549. His argument may be indirectly supported by evidence from $A E$ 1992.1872.

${ }^{89}$ Campbell 2000, LI, n.156.

${ }^{90}$ M. Troianus / M(arci) F(ilius) Marcellus / Luc(erum) Aug(ustalum) Mil(es) / Coh(ortis) X Pr(aetorianum) (Centurianae) / Scipionis / Men(sor) Lib(rator) Vix(it) / An(nos) XXV M(enses) VIIII / Mil(es) An(nos) V M(enses) VII / Fac(iebant) C(uram) / L. Magius / Adeianus et / C. Iulius Tiberinus / Amici. (CIL 6.7254).

${ }^{91}$ See: n.46 \& 48 respectively. The expression mensor agrarius almost certainly eventually morphed into the term agrimensor and should thus be translated as 'land surveyor' in both cases.
} 
and mensor librator. ${ }^{92}$ In common usage, most soldiers probably dropped the adjective gromaticus to produce the plain mensor, while the mensor librator dropped the mensor to avoid confusion when distinction seemed necessary. Such a distinction would mean that while Nonius Datus may have been the only librator in Africa he might not have been the only mensor. In spite of this interpretive flaw in Campbell's argument, his general premise is probably still valid. The mensores were a body of professional men whose training and skills were beyond the reach of most people. As a consequence there was not a lot of them and most legions probably had to get along with only a few of them. The pattern of one mensor for each cohort in a legion, and two for the first cohort was a pattern which may have existed, but which did not come into being until the early third century, a time when mensores seem to have become common enough that they even began to appear in the auxilia. ${ }^{93}$

The exact extent to which individuals had access to the technical training of the mensor and the ways in which they accessed it are a thorny problem. Sherk felt that many people would have joined the legions to receive such specialized training. This may have been the case from the mid second century on when mensores seem to have become more visible and more common. However, Sherk's assumption about training and opinion that many mensores employed their surveying skills outside the army after discharge are both fraught with problems. ${ }^{94}$ To begin with, there is no epigraphic or literary evidence to show that mensores carried on their profession as private agents after discharge. In the few instances in which it can be established that a mensor acted in a professional capacity after the normal period of service, the mensores all seem to have acted as evocati. ${ }^{95}$ As evocati they were hardly private or free agents. Secondly, if mensores were mainly trained within the ranks of the army, Marcus Troianus Marcellus could not have been a particularly skilled or highly trained mensor librator since he only served for about five and a half years. Such a short period would tell against the mensores as a highly skilled set of professionals. However, there is abundant evidence which suggests that most young men finished their general education between fourteen and sixteen, and then went on to either advanced studies in rhetoric or

\footnotetext{
${ }^{92}$ See: Hyg. De Mun. Cast. 12; CIL 3.1189; 3.3423; 3.3433; 3.8112; 3.12656; 5.936; 6.2518; 6.2692; 6.3606; $6.7254 ; 6.32520 ; 8.2564 ; 8.2728 ; 8.2946 ; 8.25988 ; 13.6538 ; A E$ 1904.72; $A E$ 1907.41B; $A E$ 1938.153; $A E$ 1941.117; $A E$ 1962.111; $A E$ 1985.843; $A E$ 1992.1872. Also see: the references in n.33 \& 36 above for definitions of gromaticus and librator.

${ }_{93}^{93}$ For examples, see: CIL 13.6538; Fink 1971, Doc. Nos.25 \& 50.

${ }^{94}$ Sherk 1974, 55

${ }^{95}$ See: n. $82,86 \& 88$ for details.
} 
philosophy if they were wealthy or into an apprenticeship of some sort if they were not. ${ }^{96}$ In some cases the apprenticeship seems to have been conducted through the army or at the least through men serving in the army. ${ }^{97}$ But in most cases, the apprenticeship seems to have been through a private person or group. This was certainly the case of the mensor Balbus.

Everyone knows, Celsus, the summit of our profession resides in you. Therefore I decided to offer up to your judgment the first product of my industry. For, although rivalry claims a place for itself amongst equals, I though that no one amongst our learned profession would promote my efforts more than the man who among them has the greatest ability in this role. Therefore, in order that a more polished version may come to the attention of certain individuals, this book should hurry to you, bearing first of all the sorts of things that are already known to you, set before you the rudiments of an apprenticeship, and share with you whatever it was able to receive from me in the midst of my military activities. And if it is deserving of going before everyone's eyes in public intercourse, it should most appropriately begin with you. Because, if you feel that too little diligence and attention have been applied to the work and thus it seems to be remiss in any respect, I shall achieve no small reward for my labor if I should through your advice take the judgment of unfriendly critics as a gain. And so, I ask, if it is not improper, that you excuse the work to the extent that it could not be brought to perfection at the time when, while our opinions were running strong, this sort of instruction was under discussion. For indeed, in my opinion, in all liberal studies its 'art' offers sufficient subject matter: in order that nothing should be lacking in this modest topic, I have applied my strength with full spirit. ${ }^{98}$

The author and his correspondent may have been former fellow students or more likely former student and teacher. ${ }^{99}$ Whatever the relationship, Balbus' words show that mensores

\footnotetext{
${ }^{96}$ See: CIL. 8.1641; 10.5056; 10.6328; Erdkamp 2005, 309-310; and Parkin \& Pomeroy 2007, 137.

${ }^{97}$ See: CIL. $6.8991=$ ILS. $7741=$ Campbell 1994, Doc No. 196. How common it was for an individual to study a trade through military service is open to dispute. The only known skill that the army can indisputably be demonstrated to have disseminated to people is that of writing and this does not seem to have been systematically taught or institutionalized. See: Bowman 1998, 91.

${ }_{98}$ Notum est omnibus, Celse, penes te studiorum nostrorum manere summam, ideoque primum sedulitatis meae inpendium iudiciis tuis offerre proposui. nam cum sibi inter aequales quendam locum deposcat aemulatio, neminem magis conatibus nostris profuturum credidi quam qui inter eos in hac parte plurimum possit. itaque quo cultior in quorundam notitiam ueniat, omnia tibi nota perlaturus ad te primum liber iste festinet, apud te tirocinii rudimenta deponat, tecum conferat quidquid a me inter ipsas armorum exercitationes accipere potuit. itaque quo cultior in quorundam notitiam ueniat, omnia tibi nota perlaturus ad te primum liber iste festinet, apud te tirocinii rudimenta deponat, tecum conferat quidquid a me inter ipsas armorum exercitationes accipere potuit. et si meretur publica conuersatione sufferre uniuersorum oculos, a te potissimum incipiat: quod si illi parum diligentem adhibitam curam esse credideris et in aliqua cessasse uidebimur parte, non exiguum laboris mei consequar fructum, quod te monente malignorum lucri fecerim existimationem. quaeso itaque, si non est inprobum, habeat apud te quandam excusationem, quod non potuerit eo tempore consummari, quo genus hoc instrumenti feruentibus studiis nostris disputatum est. omnium enim, ut puto, liberalium studiorum ars ampla materia est; cui in hac modica re nequid deesset, ingenti animo admoueram uires. (Balb. Ad Cels. 204.1-16).

${ }^{99}$ Stripping away the flowers of literary convention from Balbus' introduction to interpret the relationship between the author and Celsus is difficult. For example, the opening remarks may have been purely rhetorical and intended to convince Celsus to edit or publish the text. However, if the letters of Marcus Aurelius to Fronto are any guide, the relationship here was one of student to teacher. The difficulty of using the letters of Fronto as
} 
were trained in a collegiate and highly competitive environment. Indeed, the general tone of this passage would suggest that the education of mensores was a well-integrated extension of the traditional classical curricula, containing more than just a little philosophy and rhetoric. Assuming that Balbus' experience was not atypical, most aspiring mensores probably finished a general course of study in reading, writing, arithmetic, and perhaps a little oratory, then sought out someone who could teach them the skills while training as an apprentice. ${ }^{100}$ In 1980, Peter Brunt noted that at least some mensores organized themselves into collegia. ${ }^{101}$ Such collegia probably formed a backdrop for the discussion of various social and professional matters, including composition of technical treatises such as that of Balbus. It is also possible that such collegia mensorum functioned to facilitate training, though from what is known of other collegia it seems far more likely that such matters were generally left to private individuals. ${ }^{102}$ Regardless of the methods used for the training, the passage makes it clear that Balbus was a fully trained mensor prior to enlisting in the army. Indeed, it would seem that Balbus entered the army without any intention of using his professional training in any way, suggesting that he was both young and inexperienced in military matters.

The famous expedition of our most illustrious emperor intervened, seducing me away from speedy writing. For while I was more involved in military service, I set this entire business aside as if it were forgotten, thinking about nothing except the glory of war. After we entered enemy territory for the first time though, Celsus, at once the operations of our Caesar began to require surveying skill. ${ }^{103}$

After this declaration equating Roman military success to surveying, Balbus went on to enumerate some of his duties.

Two parallel straight lines with a fixed length of distance in between should have been provided for the roads, so that along these a great earthwork of ramparts

a guide is that they are a unique set of documents recording the relationship between a future emperor and his tutor. Without a close reading of the letters, which is outside the scope of this study, it is impossible to assess just how important such unique examples might be for understanding student-teacher relationships in antiquity. For all that, a close reading and comparison between the Marcus Fronto letters and the introduction of Balbus' work might well prove illuminating for our understanding of ancient education. On the letters of Marcus and Fronto, see: Richlin 2006, 5-9, 13-23.

${ }^{100}$ See: Mart. Ep. 9.68; P. Oxy. 18.2190; and Balb. Ad Cels. 204.3-16

${ }^{101}$ Brunt 1980, 82.

${ }^{102}$ It seems likely that collegia may have acted as central clearing houses where prospective students could seek out teachers, but that the collegia themselves were not directly involved in the educational process in any way. For discussion see fundamentally: MacMullen 1974, 72-83; also Francese 2007, 112-114.

${ }^{103}$ interuenit clara sacratissimi imperatoris nostri expeditio, quae me ab ipsa scribendi festinatione seduceret. nam dum armorum magis exerceor cura, totum hoc negotium uelut oblitus intermiseram, nec quicquam aliud quam belli gloriam cogitabam. at postquam primum hosticam terram intrauimus, statim, Celse, Caesaris nostri opera mensurarum rationem exigere coeperunt. (Balb. Ad Cels. 204.16-21). 
should rise up to protect those bringing in supplies: the use of the ferramentum, with part shaped to a point following your invention of this method, has simplified (the setting up of) these lines. ${ }^{104}$

This somewhat enigmatic and convoluted statement represents direct proof of Sherk's claim that the mensores were responsible for laying out roads. At the same time it represents the only literary description of road construction to survive from antiquity other than that provided by Statius. ${ }^{105}$ The passage is also somewhat unusual since the road system described seems to reflect a system of fortified transportation routes, something which do not seem to have been common in the Roman world. ${ }^{106}$ In describing his wish that the roads forming the military supply lines be fortified, Balbus may have been expressing an idea which was well ahead of the general concepts of the day, thus putting him on the cutting edge of surveying and military science. This is something that seems to be reflected in his subsequent remarks.

Now as it pertains to the measurement of bridges, we were able to fix the width of rivers from the near bank even if the enemy wished to prevent us from doing so. Then, with the blessing of the gods, that science showed us a way for us to work out the height of mountains which needed to be stormed. After it was tested in the momentous events in which I had participated, I began to cherish it most religiously, as if it were worshiped in all the temples, and I hurried to finish this book as if it were a religious vow to be fulfilled. Therefore, after the greatest of emperors recently had victoriously opened up Dacia, he permitted me to leave the northern regions for a period of one year, and I returned to my studies as if I was returning to a period of leisure and I gathered up the many ideas almost written out on individual leaves and scattered about so that I could incorporate them into the canon of our craft. ${ }^{107}$

\footnotetext{
${ }^{104}$ erant dandi interueniente certo itineris spatio duo rigores ordinati, quibus in tutelam commeandi ingens uallorum adsurgeret molis: hos inuento tuo operis decisa ad aciem parte ferramenti usus explicuit. (Balb. Ad Cels. 204.21-23).

${ }^{105}$ Stat. Sil. 4.3.40-55. There are other references to road construction in Livy for example, but they are not particularly descriptive or detailed. See for example: Liv. 9.29.6; 10.23.12; 10.47.4; 38.28.3. For interpretation of these passages and discussion, see: Quilici 2008, 554-556, 566-567. For discussion on the surveying methods used in the construction of Roman roads, see: Lewis 2001, 221-233.

${ }^{106}$ Note the absence of any discussion of such engineering achievements from recent works such as that of Campbell 1994; Lewis 2001; and even more specialized works such as Davies 2006 and Davies 2008, 691-711. This situation may be explained by the fact that Balbus seems to have wished for the construction of such works, which were in point of fact never built. Note the use of the subjunctive erent at the opening of the sentence in n.100. It is worth noting that while fortified roads do not seem to have played a role in any of the Dacian Wars mentioned by Balbus, they did perhaps play a part in the fortifications of Hadrian's Wall and other similar fortifications constructed in subsequent decades, suggesting that ideas circulating amongst professional mensores of Balbus' generation influenced Rome's rulers after Trajan's death.

${ }^{107}$ Nam quod ad synopsim pontium pertinet, fluminum latitudines dicere, etiam si hostis infestare uoluisset, ex proxima ripa poteramus. expugnandorum deinde montium altitudines ut sciremus, uenerabilis diis ratio monstrabat. quam ego quasi in omnibus templis adoratam post magnarum rerum experimenta, quibus interueni, religiosius colere coepi, et ad consummandum hunc librum uelut ad uota reddenda properaui. postquam ergo maximus imperator uictoria Daciam proxime reserauit, statim ut e septentrionali plaga annua uice transire
} 
Balbus is the only author in the Corpus Agrimensorum to expressly state that mensores were responsible for measuring the width of rivers in preparation for the construction of bridges. And while the task seems logical when considered alongside the other technical functions of the occupation, it is unclear as to exactly what extent the mensores were involved with such a construction venture. ${ }^{108}$ Moreover, Balbus does not mention what tools and methods may have been used for the task. Whatever they were, it seems likely that the methodology would have involved similar right triangles in a manner analogous to that employed in the measurement of mountain heights. ${ }^{109}$ This topic, which is also mentioned by Balbus, is another task that does not feature prominently in the Corpus Agrimensorum. ${ }^{110}$ This may be due to the fact that such tasks fell into the province of the librator and as such represented a technical specialty outside of the scope of general works on surveying. If this was the case, then it seems likely that Balbus was a mensor librator and that libratores were indeed the elite of the surveying profession. ${ }^{111}$

In addition to adding two further functions to the canon established by Sherk, the text of Balbus demonstrates the extent to which an individual mensor could obtain the patronage of the emperor. It is clear from the text here that Balbus' skills proved invaluable for the emperor while on campaign, but that the emperor whoever he may have been could see a wider range for the science of surveying. This would suggest that the emperors as a group did not simply introduce and maintain mensores as part of the army for military purposes. Rather, they undoubtedly retained them as a method of providing public services to the citizens of the empire, and as a vehicle through which they could demonstrate their power and benevolence

permisit, ego ad studium meum tamquam ad otium sum reuersus, et multa uelut scripta foliis et sparsa artis ordini inlaturus recollegi. (Balb. Ad Cels. 204.23-32).

${ }^{108}$ On the social perception of bridges in antiquity and their construction methods, see: Quilici 2008, 569-576; Humphrey 2006, 420-423. It is likely that the construction of a bridge such as that described by Balbus or at Caes. BG 4.17.2-12 would have involved the interaction of mensores, machinatores, architecti, fabri, and other related occupations. The nature of this interaction and its doubtless complicated social hierarchy remain unknown. For the occupations listed, see: TLL 2.465-466; 6.7-12; 6.16-18; 8.16; 8.753-754; and on the architectus, Francese 2007, 144-45. For a discussion on the machines used for the construction of a bridge, their mathematical principles, and how those principles differed from those used by the mensor, See: Wilson 2008, 340-345.

${ }^{109}$ See: Lewis 2001, 159-166 for a discussion on the calculation of mountain heights.

${ }^{110}$ There are just two other passages in the Corpus Agrimensorum, which might refer to vertical surveying. See: Campbell 2000, 240.15-25; and Front. De Art. Mens. 14.5-22.

${ }^{111}$ Some support for this argument may come from the interesting fact that the De Munitionibus Castrorum states that the castra were laid out by the gromaticus rather than the librator. Balbus does not mention castramentation amongst his duties or activities requiring surveying skill. See: Hyg. De Mun. Cast. 12; Balb. Ad Cels. 204.22-32. 
as the ultimate patron of the Roman world. ${ }^{112}$ As such, the mensores themselves could and in the case of Balbus clearly did reap rewards from such a situation. Balbus gained a leave of absence from the army that lasted an entire year. Such leave was rare in the Roman army, and reflects the importance which the emperor attached to the writing of a treatise on surveying. ${ }^{113}$ It also seems likely that contrary to the views of Michael Speidel, mensores could expect and receive promotion up to the various grades of centurion. ${ }^{114}$ However, it is not in their capacity as military officers that the mensores mainly made their presence and influence felt. Rather it was in their capacity as a conduit of knowledge, power, and patronage between the emperor and his elite officials on the one hand and the common people and soldiers on the other that manifested their social importance.

\section{MENSORES AND METATORES}

The relationship between the mensores and the metatores within the context of the castra exemplifies this social conductivity to a greater or lesser extent. Each and every castra was created for a given Roman legion or a collection of other unrelated units. As such, an aristocratic officer oversaw each. ${ }^{115}$ Most of these officers would have certainly lacked the necessary skills required for the science of castramentation and as a consequence could not have constructed a camp for themselves. ${ }^{116}$ This was probably particularly true from the mid second century A.D. when evidence suggests that the Roman castra became an increasingly

\footnotetext{
${ }^{112}$ For examples of mensores conducting surveys on behalf of the emperor or his deputies in a civilian context, see: $A E$ 1941.117 = CIL 8.2728; Plin. Ep. 10.17b.2; Elliott Doc No. 20 and following, and Cuomo 2007, 106.

${ }^{113}$ On the issue of leave, see: Just. Dig. 49.16.12.1; P. Mich. 466; and P. Oxy. 1666.

${ }^{114}$ Speidel 2001, 55-56 is of the opinion that libratores were probably not elevated to the rank of centurion. However, there seems to be evidence for the elevation of mensores to this rank, and there is no reason to assume that libratores as a subset of this trade were treated any differently.

${ }^{115}$ The exact identity of the officer responsible for overseeing the establishment of a castra is something of a mystery. Under the Republic, it seems to have fallen to one of the military tribunes who were men of the senatorial order. From the mid second century to the time of Sulla, however, it seems to have been the duty of the praefectus fabrum. This office however seems to have become an administrative post which was mostly honorific rather than functional by the mid first century A.D. and was eliminated under the reforms of Hadrian. For most of the Imperial period, the duty seems to have been performed either by an equestrian military tribune or by the praefectus castrorum, the latter being a soldier of experience raised to equestrian status. See: Dobson 2008, 50-56; Gilliver 2007, 190-192.

${ }^{116}$ Aristocratic education tended to focus on knowledge of oratory and law. So while some individuals such as Seneca and perhaps Frontinus followed up higher mathematics and the natural sciences as a branch of philosophy, most of the Roman nobility probably never bothered to study advanced geometry or the rudiments of trigonometry required for surveying. On education in general, see: Parkin and Pomeroy 2007, 136-138; Francese 2007, 22-24, 34-46. On the philosophical education of Aristocrates, see: Inwood 2005, 8-19.
} 
complex and flexible system for defense. ${ }^{117}$ Because of this, it was essential to have someone on hand that could provide the necessary technical expertise and professional skill. Some of this skill may have been provided by the praefectus castrorum, who seems to have been a professional soldier raised up through the ranks. ${ }^{118}$ However, the exact duties of the office are still uncertain, and it seems likely that even such an experienced officer may have lacked the skills to generate the triangular and hexagonal camp plans that began to emerge on the battlefields of the early third century. ${ }^{119}$ As should be clear from the discussion thus far, the mensores could and did provide such skills. However, a single mensor and even a small group of them could not lay out and oversee the construction of a camp for five or six thousand men in a short space of time. Practical considerations must have dictated that the mensores have help in their work.

From the passage of the De Munitionibus Castrorum, it is clear that the mensores of the Roman Imperial army were responsible mainly for the orientation of the castra, the establishment of its principal streets, and the outer defenses. ${ }^{120}$ This formed the axis of what modern mathematicians would call a grid and a convenient framework within which to mark out individual features of the encampment. The latter task was almost certainly the function of the metatores, who seem to have been men selected from the rank and file of the legion. ${ }^{121}$ The absence of the title from all papyrological records as well as from the wooden writing tablets and ostraka suggest that they were appointed on an ad hoc basis for a particular job, and that appointment to the post had no requirements other than practical military experience. $^{122}$

The activities between the mensores and those troops assigned to act as metatores was undoubtedly systematized and highly structured. The passages of Josephus, Frontinus, and Balbus suggest that the mensores and metatores traveled together just behind the vanguard of

\footnotetext{
117 Thomas 2004, 340-342; and Hanel 2007, 397-409. See: Dobson 2008, 68-121; Richardson 2004, 3-35; Welfare \& Swan 1995, 9-18;

${ }^{118}$ For discussion of this officer, see: Saddington 1996, 244-252; and Gilliver 2007, 191.

${ }^{119}$ Welfare and Swan 1995, 12-15; and Veg. Mil. 3.8.6.

${ }^{120}$ Hyg. De Mun. Cast. 12. See n. 33 \& 34 of this chapter for text and translation.

${ }^{121}$ See: $4,5,9 \& 10$ for relevant texts.

${ }^{122}$ Measuring distance by pacing and the use of the decempeda seems to have been part of every soldier's training. See: Veg. Mil. 1.1.9, 1.1.19. The basic principles of the right triangle which would have been needed for marking out tent space within the camp could probably have been taught in an afternoon. The author himself in 1998 participated in an American archaeological project where forty high school students were taught to lay out a grid using the right triangle in half an hour. Roman soldiers may not have been as educated as the modern American high school student, but their intelligence was probably equivalent.
} 
the army. ${ }^{123}$ References in the De Munitionibus Castrorum describing the legion marching six abreast suggest that there was perhaps a numerical system of marching order that was dependent on the numbering of the individual centuries within a cohort. ${ }^{124}$ If such an ordering existed and also applied to the metatores and / or mensores, then such system would probably have influenced the order in which the metatores established camping sites within the grid frame laid out by the mensores. The fact that pre-designated plans or podismoi for the castra seem to have existed lends added credence to such a system. ${ }^{125}$

Apart from the system of castramentation, which can only be illuminated in an incomplete manner, there is evidence that suggest metatores may have been employed under mensores for other surveying jobs. The first piece of evidence comes from yet another passage of Nonius Marcellus.

Metators (metari), "to prepare" (parare), and from this the "boundary markers" (metatores).

Virgil, Georgics 2.274: "If you will mark out fertile fields of the level plain, plant close."

Likewise, Coelius: The Annals Book 6: "All at once everyone gathered on shore with the fleet, beached the ships and light craft, set up the battle standards, and marked out the camp."126

In this passage Nonius drew on two unrelated texts to show that he felt that there was a close association between the concepts of metari to mark out, parare to provide or ready, and

\footnotetext{
${ }^{123}$ See: Front. Strat. 2.7.12; Jos. BJ 3.115-118; 5.47; Balb. Ad Cels. 204.21.

${ }^{124}$ Hyg. De Mun. Cast. 2 states that a cohort in a single column of march occupies a space 30 feet wide and 720 feet long. Each cohort contained 480 men divided into 6 centuries. Jos. BJ 3.124 states that the legionaries marched six abreast, suggesting that each century had a line in the column of march with each soldier in the line occupying a space 5 feet wide and 6 feet in depth.

${ }^{125}$ The evidence for a theoretical plan for a Roman castra is slim but not negligible. The texts of Polybius and the De Munitionibus Castrorum both suggest it. Additional support comes from the fact that Vegetius uses the word podismus when discussing the role of the mensores in the Roman army. Podismus means ground plan and has an architectural flavor. See: Polyb. 6.26.10; Hyg. De Mun. Cast. 21; and Veg. Mil. 2.7.9; 3.8.3-4. Any attempt to reconstruct the system of castramentation beyond this vague concept seems impossible at this time. It would necessitate grafting the theoretical models found in imperfectly preserved text onto a bewilderingly diverse array of archaeological sites, which tend to be labeled as castra. Most sample castra are known from Britain and only a few have been excavated or otherwise fully investigated. A full investigation of multiple sites against a comprehensive understanding of the mensores, metatores, and the theoretical concepts behind the evolution of the castra would be required for a proper reconstruction. For further discussion, see: the references in $n .113$ above.

${ }^{126}$ Metari, parare, unde et metatores. Vergilius Georgicorum lib. II (274) 'Si pinguis agros metabere campi, Densa sere: i.d.' Coelius Annali Lib. VI: 'Omnes simul terram cum classi accedunt, navibus atque scaphis egrediuuntur, castra metati signa statuunt'. (Non. 137.10-18).
} 
metator. As has been shown elsewhere, Nonius Marcellus' conclusions were not always based on full knowledge. Even so, his textual selections have logic to them and perhaps reflect a more nuanced picture of circumstances in antiquity than modern scholars normally allow.

Nonius' quoted passages show that the term metari gave rise to metator, and that metari was an action associated with land ownership and cultivation. The mensores were also bound up with marking out land, land ownership, and cultivation. Thus, it is not difficult to reach the conclusion that metatores and mensores were the same through a faulty leap in logic. But it is important to keep in mind that Nonius himself did not make that connection. In his passage on finitores, he actively equated that term with agrimensor. Yet, in his passage on the metatores, he made no such direct association. Likewise, in his discussion of the groma, Nonius mentioned agrimensores and mensores quoting a passage of Lucilius by way of example, but he did not introduce the concept of the metatores. ${ }^{127}$ This passage reinforces the concept that there was a difference between mensores and metatores while insinuating a connection to surveying both in the military and agricultural spheres for both.

The simple explanation that leaps to mind is that metatores were assigned to work under mensores not only in the context of constructing a castra, but for any large scale surveying project undertaken by the Roman army. As was noted above, the Roman army undertook massive surveying projects, which would have been well beyond the abilities of an individual or even a small group of mensores. In Africa and along the Danube River hundreds of square kilometers of land were quickly subjected to centuriation. It has long seemed a marvel of surveying skill even to modern observers. Yet, if a small group of mensores from a legion were assigned what seems to have been a full complement of metatores, the rapid centuriation of newly conquered territory becomes explicable. The mensores operating under the command of an equestrian or senatorial officer would have directed operations, focusing on things which were technically difficult or which required legal knowledge. The more basic chores such as pacing the lines of the grid would have been left to the less skilled enlisted soldiers assigned as metatores.

${ }^{127}$ Non. 9; Lucil. Fr. 98-100. 
While this system explains how the Roman military was able to carry out many of the more impressive feats of surveying, it leaves almost as many questions as it answers. It seems clear from the textual evidence that the metatores and mensores were socially and technically very different from the equestrian finitores. Likewise, it seems likely that the differences between the mensores and metatores were less a question of social background than one of knowledge and training. The mensores had access to specialist knowledge making them an essential link between the aristocratic leaders and the common soldiers or people. ${ }^{128}$ What is less clear however, is exactly when this relationship and its related systems came into being. Evidence from Polybius and Lucilius indicate that there were enlisted soldiers responsible for marking out the camp in the second century. ${ }^{129}$ But those soldiers even if called mensores, may not have operated with the system of metatores outlined here. In essence, the question is when did the mensores become professional surveyors as modern scholars understand them from the Corpus Agrimensorum? Did the mensores and metatores exist as part of the Republican colonial boards or did they only come into being in the first century B.C. in response to social and political changes that the old system was unable to manage? Answering such questions requires that the mensores, metatores, and the source material for their existence under the Republic be examined against the social and political events of the first century. Such an examination would be a complex undertaking, which must by necessity form the subject of a separate inquiry.

\footnotetext{
${ }^{128}$ Cuomo in her recent publication identifies this social relationship, and to a great extent explores it and the implications of possession based on specialist knowledge. See: Cuomo 2007, 108-129 for her stimulating discussion of the topic.

${ }^{129}$ Polyb. 6.26.10; 6.42; Lucil. Fr. 100
} 


\section{CHAPTER THREE ROMAN SURVEYORS FROM SULLA TO CAESAR}

And you will mark out your path in a straight line, just as the surveyor has long done for a camp. ${ }^{1}$

But when aging Saturn held sway over the world, the Earth hid all her wealth in deep darkness. She stored bronze and silver, gold and heavy iron with the shades, there weren't any ingots then. Then she gave better things-crops without a curved plowshare and fruit and sweet honey found in the hollow oak-tree. No one split the earth asunder with the strong plow's blade, the surveyor did not mark out the land with a boundary, no one swept the churning sea with a dipping oar; the furthest mortal journey ended at the shore. ${ }^{2}$

The satirist Lucilius wrote the first passage cited here in the last decade of the second century B.C. ${ }^{3}$ This passage clearly shows that mensores existed in the time before Caesar's dictatorship, the time when mensores are next attested in our surviving sources. ${ }^{4}$ However, it is unclear whether or not the mensores mentioned by Lucilius were the same as those mentioned by Ovid. ${ }^{5}$ In this chapter we will examine the identity of the mensores mentioned by Lucilius in the context of the second century B.C. and trace the social and political forces, which forced their evolution, giving rise to the mensores as they were recorded in the Corpus Agrimensorum.

\footnotetext{
${ }^{1}$ Viamque degrumabis uti castris mensor facit olim. (Lucil. Fr.100).

${ }^{2}$ At cum regna senex caeli Saturnus haberet,/ omne lucrum tenebris alta premebat humus./ aeraque et argentum cumque auro pondera ferri / manibus admorat, nullaque massa fuit./ at meliora dabat - curvo sine vomere fruges/ pomaque et in quercu mella reperta cava./ nec valido quisquam terram scindebat aratro,/ signabat nullo limite mensor humum,/ non freta demisso verrebant eruta remo;/ ultima mortali tum via litus erat. (Ovid, Am. 3.8.35-44).

${ }^{3}$ For details on Lucilius' life, see: Conte 1999, 112-116.

${ }^{4}$ See: Varr. $R R$ 1.10.2. On the dates of composition see: Conte 1999, 211-212.

${ }^{5}$ It is an interesting fact that nearly all the Augustan authors mention surveying, land confiscation or cartography, but only Ovid actually names the mensores as land surveyors. A passing reference to mensores in the Odes of Horace seems to reflect a philosophical measurer rather than a land surveyor as such. For surveying, see by way of example: Liv. 1.10.5; 1.56.1-3; 3.1.1-7; 9.46.1-3; 10.21.7-10; 21.25; Hor. Sat. 2.6.51-58; Hor. Od. 1.28.1-16; Ovid. Am. 3.8.35.44; Met. 1.125-143. Whether Ovid's use of mensor and the associated concepts of surveying owe more to the works of Varro or to the ideas of land confiscation in Vergil is difficult to say. Both authors seem to have been influential in the age of Augustus. For a stimulating discussion of land confiscation and surveying in the early work of Vergil, see: Saunders 2008, 89-101. For the influence of Vergil on Ovid's poetry, see: Thomas 2009, 294-307.
} 
Evidence for the involvement of the mensores in the army of the Imperial period is abundant. ${ }^{6}$ If one examines this evidence against the text of Lucilius one may be forgiven for thinking that the imperial system of castramentation, as described in Chapter Two was an institution that stretched back to the time of Marius. ${ }^{7}$

In spite of this documentary evidence, there are sound reasons for rejecting the idea that the metatores and their relationship with the mensores go back so far. Firstly, the high degree of social distinction indicated by the relationship between the mensores and the metatores which can be found in imperial literature reflects a high degree of specialization not attested in Roman society before the age of Sulla. Secondly, it is important to remember that mensores of the imperial period were more than just technical experts: they were legal experts too. ${ }^{8}$ Existing evidence indicates that such juridical specialists from outside the senatorial and equestrian orders did not exist before the mid-first century B.C. ${ }^{9}$ As a consequence, the mensores described by Lucilius, whatever their social identity, could not have been like the mensores described in the Corpus Agrimensorum.

The text of Lucilius would seem to suggest that the mensores of the second century B.C. were more like the metatores of later generations. An examination of several passages from the Histories of Polybius would seem to strengthen this impression. Polybius does not provide a comprehensive description of Roman castramentation, being more interested in the aristocratic elements of the army and its general constitutional role in the Roman Republic. However, his description is sufficiently detailed for modern scholarship to reconstruct the general organization of the castra he was describing and some of the people responsible for its construction. ${ }^{10}$

\footnotetext{
${ }^{6}$ See for example: Hyg. De Mun. Cast. 12; Veg. Mil. 2.7.6-9, 3.8.3-4, and the discussion in Chapter Two of this study.

${ }^{7}$ For a full discussion of this system, see: Chapter Two of this study.

${ }^{8}$ See: Dilke 1971, 31-33, 43-46; Campbell 2000, introduction XLVIII-LI; Cuomo 2000, 192-193; and Cuomo 2007, 106-131.

${ }^{9}$ See: Frier 1985, 204-205; Harries 2006, 3-4; and Lintott 2008: 70, 72, 73, 80 n.37.

${ }^{10}$ In general, for Polybius' description of the camp see: Polyb. 6.27-35; and 6.41. For two radically different reconstructions of the Polybian camp by modern authors, see: Salvatore 1996, 5-20, 139-154; and Dobson 2008, 71-100. Of the two reconstructions, Dobson's is perhaps the more balanced and logical, but there does not seem to be any way of establishing one theoretical reconstruction as more factually correct than the other. As Salvatore notes at the opening of his discussion, Polybius' account of the camp is far from straightforward and problem-free: Salvatore 1996, 5-6.
} 
At the outset of his description, Polybius established that there was a universal ground plan or podismus, which could be adapted to the construction of any fortified possession the Romans wanted to occupy. ${ }^{11}$

Having arranged all this satisfactorily, the military tribunes (chiliarchs) taking control of the army set up a camp for both Romans and allies together, there being a single simple scheme (theorema) among them for encampment which they adopt at every time and place. $^{12}$

If such a plan existed in the middle Republic, then it was probably written out as a set of schematic instructions, which could be adapted to any situation by any literate individual with a good working knowledge of mathematics. As such, the plan was probably not particularly exact or structured. Furthermore, the plan was probably kept as part of the body of religious law overseen by the augures. Evidence for this can be found in the fact that the praetorium was a templum or religious enclosure for taking the auspices, and as such it was a religious space governed by augural law and the augures. ${ }^{13}$ Polybius does not mention the presence of an augur as part of the group of officials selecting or establishing a campsite. But by the same token, he does not seem to have been particularly interested in the religious rituals associated with Roman war-making. ${ }^{14}$

Without a contemporary source, it is impossible to say to what extent the augures were involved with the actual tasks of castramentation. In the early days, it is quite possible that they actually laid out the square, which formed the praetorium and thus established the foundation for the grid that structured the camp. By the mid second century however, it seems likely that the augures' work was mostly supervisory, ensuring that the hierarchical group detailed off for camp construction followed the podismus and adapted it to the needs of the location in accordance with ancestral usage. There is a considerable body of evidence

\footnotetext{
${ }^{11}$ On the concept of the podismus compare Polyb. 6.26.10, 6.32.1-2; Hyg. De Mun. Cast. 21; and Veg. Mil. 2.27.9 \& 3.8.3-4. For modern references to the concept, see: Dobson 2008, 67; and Richardson 2004, 4-10.

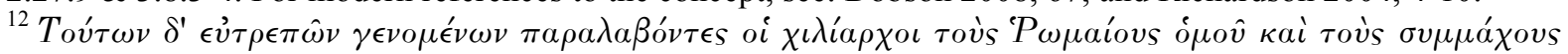

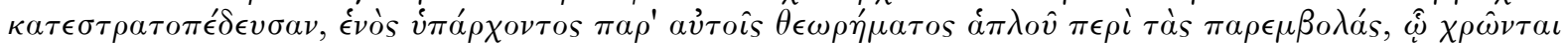

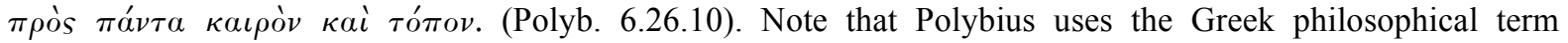
theorema to describe the Roman concept of a plan, suggesting that as Polybius states later, the Greeks had no such concept and no single word for it. See: Polyb. 6.42.

${ }^{13}$ See: Hyg. De Mun. Cast. 12; Liv. 41.18.8; Linderski 1986, 2, 16.3, 2151-2153, 2174, 2276-2277; Harries 2006, 163-164; and Dobson 2008, 71-79.

${ }^{14}$ See: Polyb. 6.41. The only religious ritual that Polybius seems to record in the context of the Roman castra and its construction is that of sortition or the drawing of lots, and he describes it more as a decision-making system rather than a religious ritual. See: Polyb. 6.34-35.
} 
suggesting that this usage probably changed over time to fit the needs of the Roman state. ${ }^{15}$ Along with changes in usage and the changes in castramentation, we should also probably expect at least some change in the people responsible for establishing the castra.

The following passage demonstrates the basic principles of castramentation and the people involved in that process. Polybius described how at the end of a day's march a tribune and some centurions were sent in advance to select and lay out an encampment:

On the march, whenever the army is approaching the place in which it is to make camp, a tribune and those of the centurions who are chosen for the task always go in advance. Surveying the whole area where the camp is to be pitched, they select, in accordance with the explanation above, the place that the consul's tent will occupy and on which side of this space around the tent the legions should encamp. $^{16}$

Polybius describes the system of castramentation referred to here in several of his previous chapters. ${ }^{17} \mathrm{He}$ describes an ingenious system of lines and interlocking squares, which as this passage indicates used the location of the consul's tent as a starting point. ${ }^{18}$ As should be evident from the discussion of the mensores in the previous chapter, imperial texts make it clear that this use of the commander's tent as a locus gromae was a fixed feature of Roman camp construction under both the Republic and Empire.

The manner of the Roman camp is as follows. When the site for the camp has been selected, the consul's tent occupies the spot, which is most suitable for observation and command. When the standard has been placed where they intend to pitch this tent, a square area is measured out around the standard, so that all sides are 100 feet from the standard. The area is equal to four plethora. ${ }^{19}$

\footnotetext{
${ }^{15}$ For some profound thoughts on this subject, see: Wallace-Hadrill 2008, 217-218, 225-226, \& 231-249.

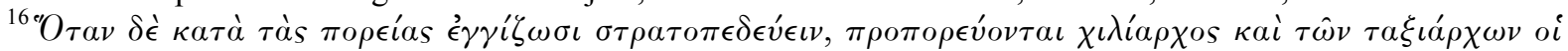

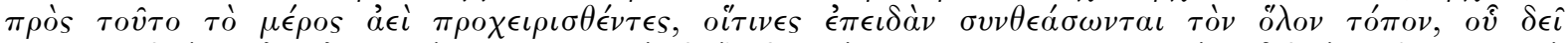

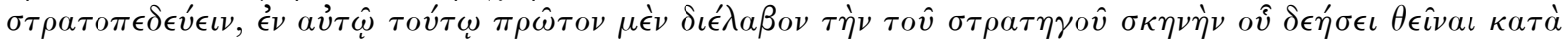

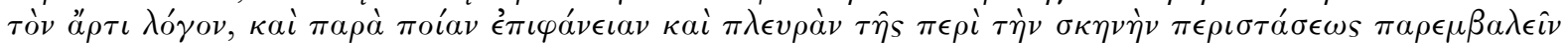
$\tau \dot{\alpha} \sigma \tau \rho \alpha \tau o ́ \pi \epsilon \delta \alpha \cdot($ Polyb. 6.41.1-2).

${ }^{17}$ See: Polyb. 6.27-31. 6.27.1-3 is of particular interest as its language echoes that of 6.41.1-2 and was presumably the passage Polybius had in mind when writing 6.41. Given this fact, it is possible to see a tight description of castramentation, which is framed by similarities in its opening and closing. In its fullest extent, it runs from 6.27.1 to 6.41.12; though one might make a case that 6.42.1-5 should also be included. I do not include it as it seems to be more of an introduction to Greek concepts of government and their differences from those of the Romans, which occupy 6.42 and several following chapters. For discussion and commentary on these passages, see: Walbank 1957-79.

${ }^{18}$ For a diagram of Polybian camp, see: Fig. 5.

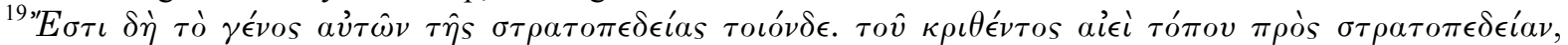

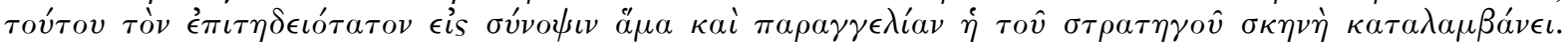

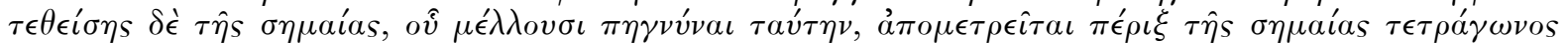


In addition to the locus gromae (which Polybius does not name) the camps of the Republic and Empire also were both traditionally described as being fortified by a rampart and ditch. ${ }^{20}$ The bank and the ditch were separated by an open area known as the intervallum. ${ }^{21}$

The over-all shape of the camp seems to have changed from the beginning of the second century B.C. through the sixth century A.D. when it dropped out of use as a defensive system for armies in the field. These changes were almost certainly driven by alterations that took place in the organization of the Roman army, battlefield tactics, and in all probability, by refinements in surveying practices. ${ }^{22}$ Because of a dearth of archaeological evidence for castra of the Republican period, the exact course of evolution in castramentation can only be sketched in the broadest terms.

The best-stratified remains of Republican castra have been unearthed at Renieblas, a site not far from the fortified stronghold of Numantia in modern day Spain. Here the German archaeologist Adolf Schulten excavated several camps, which he considered to have been superimposed, one on another, and which reflected Republican castramentation. ${ }^{23}$ Recent work done at the site has refined our understanding of this stratigraphy. For example, some of the strata that Schulten considered to have been contemporary phases of occupation should in point of fact be seen as separate periods of occupation. ${ }^{24}$ In addition, this work has revealed a number of new features associated with the camps, which Schulten overlooked. ${ }^{25}$ Because of this, and because of a number of refinements in archaeology that have taken place in the decades since Schulten published his reports in 1929, archaeologists have attempted to redate and re-evaluate the finds associated with these camps to improve our understanding of Roman castramentation. Each reassessment has yielded different interpretations, making detailed understanding of specific refinements in the castra problematic. However, the archaeologists do seem to have arrived at some general understanding, which can be

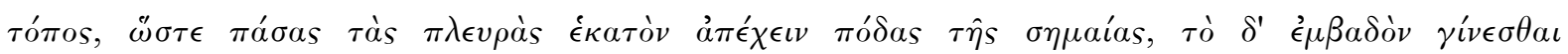
$\tau \epsilon \tau \rho a ́ \pi \lambda \epsilon \theta \rho o \nu$. (Polyb. 6.27.1-2). For the consul's tent as a locus gromae see also: Chapter Two, ns.12 \& 33.

${ }^{20}$ Polyb. 6.34.1; Hyg. De Mun. Cast. 48, 49, 50; Lenoir 1979, 81-84, 90; Dobson 2008, 97, 109, 119.

${ }^{21}$ Polyb. 6.31; Hyg. De Mun. Cast. 14; Lenoir 1979, 30; Dobson 2008, 97, 109.

${ }^{22}$ For discussions, see: Welfare 1995, 9-18; Richardson 2004, 11-32; Hanel 2007, 397-409; and Dobson 2008 , 56-64, 101-119, \& 406-415.

${ }^{23}$ Salvatore 1996, 22-30; Dobson 2008, 12-20.

${ }^{24}$ Salvatore 1996, 77-78; Dobson 2008, 189-193.

${ }^{25}$ Dobson 2008, 198-199.
} 
employed for the purposes of this study in relation to the increasingly sophisticated technique of castramentation/surveying.

Broadly speaking, there seem to have been at least five and perhaps as many as seven phases of occupation at the site of Renieblas. ${ }^{26}$ Schulten referred to these phases as Lagers and assigned both relative and historical dates to each. ${ }^{27}$ The historical dates have been disputed on good grounds, though the corrections suggested are not all as convincing in every respect as one might wish.

The camp at Lager I, dated to the beginning of the second century B.C., consisted of a badly broken outer stone wall with irregularly placed gates, some internal stone buildings, and no defensive towers. $^{28}$ Lager II, having roughly the same date and similar construction, lacked stone buildings. ${ }^{29}$ By contrast, Schulten dated his Lager III to 152 B.C., a date that can probably be accepted based on numismatic and epigraphic evidence. ${ }^{30}$ It was constructed with thick stonewalls, a number of watchtowers, and at least four regular gates. ${ }^{31}$ The internal evidence surviving in the records indicates that the camp was intended for two legions with a manipular structure and a large number of allied troops. ${ }^{32}$ The strata known as Lagers IV and $\mathrm{V}$ are both difficult to date. ${ }^{33}$ The remains are badly preserved and may reflect a manipular military organization and Dobson would like to date them to Scipio's siege on Numantia. ${ }^{34}$

\footnotetext{
${ }^{26}$ Salvatore 1996, 21-22; Dobson 2008, 125-126.

${ }^{27}$ A summary of Schulten's chronology and dating along with some of the problems with it can be found in Salvatore 1996, 23-29; and more comprehensively in Dobson 2008, 385-405. Dobson specifically discusses the castra at Renieblas on 385-387. His discussion takes account of some new archaeological work done around Numantia in the last seven years and is far more detailed and exacting than that of Salvatore. Even so, Dobson's conclusions show that there is still plenty of work to be done on the Republican camps in the area if we are truly to understand the development of Republican castramentation and the place of the Numantine castra in Roman history.

${ }^{28}$ Salvatore 1996, 21, 31-32; Dobson, 127-131 \& 385.

${ }^{29}$ Salvatore 1996, 21, 32-36; Dobson 2008, 126, 131-134, 385. For diagrams of Lagers I \& II, see: Fig. 6.

${ }^{30}$ Salvatore 1996, 21; Dobson 2008, 32, 34-35, 386. For a diagram of Lager III, see: Fig. 7.

${ }^{31}$ Dating depends entirely on how the internal structural remains and pottery evidence are interpreted. See: Salvatore 1996, 33-36; Dobson 2008, 134-188. Dobson's description includes many more plans than does Salvatore and examines issues, which Salvatore takes up in other sections of his text. Most important of these topics are a reassessment of the barrack blocks Schulten found in Lager III and their impact on our understanding of the structural changes which took place in the Republican army of the second century B.C. See: Salvatore, 135-154 for his thoughts on these topics and related matters.

${ }^{32}$ Dobson 2008, 183-187, 386.

${ }^{33}$ Salvatore 1996, 27-30, 117-130; Dobson 2008, 35, 194-197, 386.

${ }^{34}$ Dobson 2008, 200-206, 230-234, 386. For a summary of the siege works, their dating and reinterpretation after the work of Schulten, see: Dobson 2008, 387-404
} 
If we accept the testimony of Polybius and this chronology as both Salvatore and Dobson do, then a pattern of development can be deduced for the development of the castra during the second century B.C. Polybius describes what has been interpreted as half of a double consular castra intended for four legions. ${ }^{35}$ This system of encampment seems to have been reasonably common just before and during the Second Punic War even though no archaeological evidence has survived to attest it. In the period following the Hanibalic invasion of Italy, the Romans seem to have developed the practice of dividing the double consular castra and modifying its internal structure for a double legion, single consular configuration. This sort of castra can be archaeologically attested if the remains of Lager I have been properly interpreted. Such early castra seem to have followed the contours of the landscape far more than Polybius would allow. ${ }^{36}$ They also seem to have had far fewer regular features, which might be associated with a prefabricated podismus, than did later examples of castra. This situation may provide some corroboration for recent archaeological work which indicates that the system of centuriation associated with the colonia did not develop until the late third century B.C. and that the standard grid based on an actus of 120 Roman feet did not come into being until the mid second century B.C. ${ }^{37}$ If the systems of castramentation and centuriation came into being at this point and evolved slowly, we might expect the skill level of the Roman surveyors to have also evolved along with these systems.

During the course of the first half of the second century B.C., the Romans seem to have regularized the plan for the castra and added a number of new features. These castra features seem to have included watchtowers, regularly positioned gates, and perhaps artillery platforms, presumably requiring a refinement in surveying skills. ${ }^{38}$ From around 150 B.C. the internal structures seem to have undergone a transformation reflecting the evolution from

\footnotetext{
${ }^{35}$ See: Polyb. 6.27; 6.32; 6.34; Walbank; Salvatore, 6-9; Dobson 2008, 68-72.

${ }^{36}$ Compare Polyb. 6.42.1-5 with the plans and diagrams provided for Lager I at: Dobson 2008, 129-131.

${ }^{37}$ Arguments for a decentralized colonia, with little or no formalized centuriation, in the period before the Second Punic War were first forcefully put forward by Edward Bispham in 2006. Jeremia Pelgrom has since advanced the argument. And while the argument has a number of attractive features that help explain anomalies in the archaeological record, it primarily depends on a skeptical reassessment of existing survey information and the absence of direct settlement data associated with centuriation in a third century context. As stated here, the evidence from Lager I may help indirectly support Pelgrom's arguments about the development of early Roman coloniae. However, proving the full theory advanced by Bispham and adopted by Pelgrom will take a great deal more fieldwork. Because of this, it seems best to adopt their arguments only on a provisional basis while allowing the older views more voice until further evidence comes to light. For more on this, compare the diagrams and discussion of Dobson 2008, 127-131, 135-185 with Bispham 2006, 81-88; and Pelgrom 2008, 334-335 \& 361-369.

${ }^{38}$ See: Dobson 2008, 135-55, 386.
} 
maniple to cohort. ${ }^{39}$ This transformation seems to have been completed by around 100 B.C., though Dobson feels that the Roman army still employed the manipular structure on occasion in later times. ${ }^{40}$

Exactly what changes took place in the plan of the castra during the period from Sulla to Augustus are not known. However, it seems probable that the castra continued to exhibit increasing signs of a tighter organization and regularization reflecting the increasing professionalism of the Roman army. Remains of castra, which archaeologists have associated with the Augustan occupation of the German provinces, suggest that the castra of this period were beginning to show the regular rectangular shape traditionally associated with the Roman fortresses of the Imperial army. ${ }^{41}$ However, this famous playing-card shape with its rounded corners does not seem to have been fully developed until the mid-first century A.D. and is perhaps to be associated with the reign of Claudius. ${ }^{42}$ The playing-card fortress seems to have been employed with regional variations and minor refinements until perhaps the late second century A.D. at which point a number of unusual shapes such as triangles, hexagons, and even elliptical encampments seem to appear on the Roman battle field. ${ }^{43}$ It would have been far more difficult to adapt the Roman grid system used for encampment to these unusual configurations. It is possible that these shapes reflect an increased sophistication in Roman surveying, which was the result of the incorporation of professional surveyors or agrimensores into the ranks of the Roman army as part of a gradual process. This course of development, if correct, raises a number of interesting questions about the origin of both the fortified castra and the organization, which enabled the Romans to construct it.

It has been postulated that the Roman castra had its origins on the hard-fought battle fields of the Pyrrhic War around 270 B.C. ${ }^{44}$ Such a conjecture, while not unrealistic, seems to argue for a combination of desperation and Greek influence as the seed of germination for the idea of a fortified encampment. Such an idea has its attractions and possibilities. As has been

\footnotetext{
${ }^{39}$ On the development of the maniple and its workings see: Rawlings 2007, 55-59. On the cohort, see: Gilliver 2007, 189-191; and Dobson 2008, 58-62, 3856-391, 409-414.

${ }^{40}$ Dobson 2008, 407 supported by Rawlings 2007, 46-8.

${ }^{41}$ Hanel 2007, 398-399.

${ }^{42}$ Thomas 2004, 340-342; Hanel 2007, 399-400.

${ }^{43}$ Compare Hyg. De Mun. Cast. 21 with Veg. Mil. 3.8 .4 and consult Welfare and Swan 1995, 9-22, for discussion. It is not possible to date most remains of Roman marching camps at this time due to a lack of proper excavation. However, most of the hexagonal and triangular samples in Britain seem to be located in a Severan context.

${ }^{44}$ Richardson 2004, 11.
} 
noted elsewhere, the Spartans organized the military camps in a circular pattern around the tent of their King, much like the locus gromae. ${ }^{45}$ In addition, there were armies in the near East which used fortified encampments in the fifth and fourth centuries B.C. ${ }^{46}$ Both principles were known and to some extent at least practiced by the Macedonian army during its invasion of Italy. In fact, the Romans themselves saw these techniques after encountering the Macedonians, incorporating various innovations of their own. The Roman innovations produced the polygonal encampment surrounded by a palisade and ditch, as is described by Polybius and many other authors.

Recent work questioning the use or existence of regularized centuriation in a colonial context, however, gives ground for hesitation in accepting the direction of Greek practices by the Romans. If scholars such as Bispham and Pelgrom are correct in their conjecture that regular centuriation did not come into use until the mid to late third century B.C., then it is quite possible that the fortified castra described by Polybius did not come into existence until just before the Second Punic War and that it was the end-product of a long period of experimentation in response to a complex array of problems faced by the Romans on the battlefield. Four pieces of evidence exist to support such a possibility. The first is the level of organized structure found within the remains of the castra excavated in Spain. As stated above, the earliest of these castra had stone-built internal buildings with some degree of regularity, but lacked the regularity and planning of later versions. This would suggest that the concept of the podismus may have still been evolving at the start of the second century B.C. Second, the text of the De Munitionibus Castrorum contains brief descriptions of systems of encampment which seem far simpler than that of the fortified Polybian castra and which may thus predate it. These passages suggest that the system of camp layout evolved over time, and presumably so did the role of those responsible for marking them out.

The spiked barricades are the trunks of trees with many branches. One is driven to this tactic if by the nature of the soil, the turf breaks apart from excessive softness or a sufficiently sturdy palisade cannot be raised with portable stone, or a ditch cannot be created so that the sides do not collapse. ${ }^{47}$

\footnotetext{
${ }^{45}$ See: Xen. Lac. 12.1-4.

${ }^{46}$ See: Xen. Cyr. 3.3.24-27; 8.5.8-14.

${ }^{47}$ Cervoli trunci ramosi. Ad hos decurritur si soli natura nimia teneritate cespes frangitur neque lapide mobili satis copiosum vallum extrui potest nec fossa fieri ut non ripae decidant. (Hyg. De Mun. Cast. 51).
} 
Whenever barricades are absent and the position is more suspect, the troops defend the camp with 4 ranks of armaments and pickets are placed densely throughout the individual ranks and cavalry should circle the camp in reciprocal succession. If in friendly country, a single row of armaments is sufficient merely for the sake of maintaining discipline and the pickets are positioned more sparsely. ${ }^{48}$

Both the use of picots and spiked barricades constructed from the trunks of trees represent methods of fortifying a temporary camp which would be far easier and less complex than the construction of a bulwark and ditch (which during the imperial period became increasingly sophisticated with time). It seems impossible to establish beyond doubt that these methods described by Hyginus predate the Polybian system of castramentation, but the evolution of ideas tends to proceed from simpler to more complex. It seems very probable but not provable that Hyginus is describing the early stages of the development of the castra.

As support both for the concept of simpler systems being older, and for their continued use under the Principate alongside more complex systems, one can turn once again to archaeology. Brian Campbell in 1996 demonstrated that older systems of land division associated with the middle Republic which are known as strigation and scamnation continued to be used in the Empire for establishing field systems in mountainous terrain. ${ }^{49}$ If the Romans could maintain older systems of surveying alongside the more complex system of centuriation, then it seems quite probable that older systems of castramentation would also survive for use under specific circumstances as the author of the De Munitionibus Castrorum indicates.

If the concept of the castra, evolving slowly from an earlier non-fortified encampment is accepted, then it seems equally logical that the organization instituted for its construction also changed. Unfortunately, it is almost impossible to assess how from the available documents.

Polybius at one point in his narrative of the Roman constitution says:

\footnotetext{
${ }^{48}$ Quotiens cervoli desunt et est locus suspectior, armorum ordinibus [castrorum] IIII castra muniunt et per singulos ordines vigiliae crebrius ponuntur; et equites alterna vice castra circuire debent. Si in pacato solummodo tuendae disciplinae causa, unus ordo armorum sufficit et vigiliae rarius constituuntur. (Hyg. De Mun. Cast. 52).

${ }^{49}$ Campbell 1996, 86.
} 
Given the number of infantry and cavalry, whether they be either four thousand or five thousand in each legion, and likewise given the breadth, length, and number of standards and units, and the size of the roads and open spaces and all other things, those who wish to apply their minds to it can calculate the size and total area of the camp. ${ }^{50}$

This statement suggests that Polybius felt that anyone with intelligence, knowledge of the army, and the ability to read the directions could lay out a castra. It also indicates that there were not any technical specialists involved with castramentation in the second century B.C.

Two later passages provide some idea of who was, in Polybius' mind, responsible for laying out the castra. Here Polybius' reference to tribunes and centurions shows that the role of a technical specialist for camp construction had not yet evolved:

Whenever the Romans on the march approach the place where they are to encamp, the tribunes and some of the centurions, who are frequently chosen for the work, go in advance and, after surveying the whole area, there on that spot, they mark out the place where the consul's tent must be pitched. And with this chosen, they measure out the surrounding area of the tent and among this, the straight line along which the tents of the tribunes are placed, and next a parallel line to this from which the camp begins to be laid out. And in a similar manner, they measure out along the other side of the tent with lines which we have discussed in more detail above. This happens in short order because the surveying is easy as all the boundaries and intervals are regular. Amongst other things, they first place a flag at the spot where the consul's tent must be pitched, a second they plant along the front side, a third in the middle of the line along which the tribunes are to encamp, and a fourth on the side where the legions are to encamp. They make the outer flags red, but the consul's flag white. Sometimes they plant bare stakes for the others, sometimes stands of other colours. When this is done, they measure out streets and plant stakes along each street. From which reasonably, whenever the army nears on the march, the place of the camp is easily seen and immediately everything is well known to all by being arranged and calculated from the standard of the general. Now as each one clearly knows in which street and on what part of the street he is billeted on account of everything having the same place in the camp, it happens to resemble a native army entering into [its] city. For then turning away from the gates, immediately each goes forth and comes to [their own] private dwelling without error, in general and in specifics he knows where his billet is. This also occurs to them in the case of the Roman camp. ${ }^{51}$

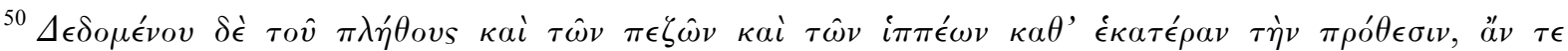

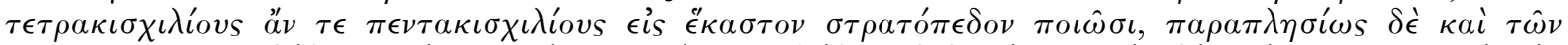

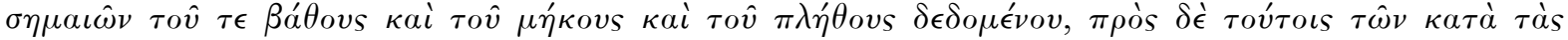

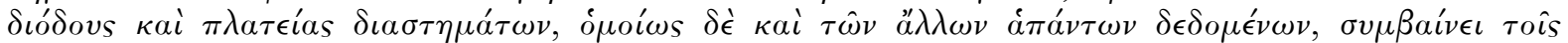

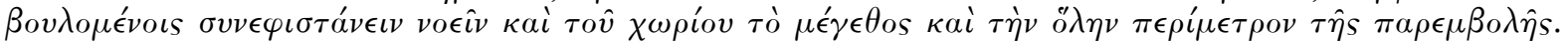
(Polyb. 6.32.1-2).

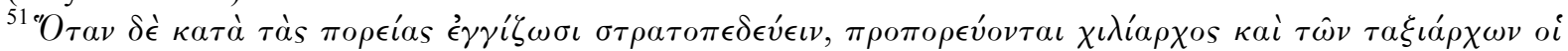

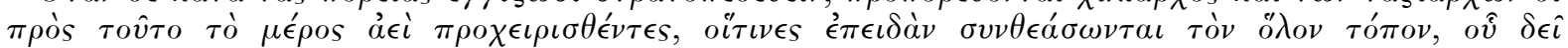


This passage shows that a senatorial tribune and a group of centurions were, in Polybius' opinion, responsible for going in advance of the main army and laying out the camp. However, while the castra he describes may have been in principle easy to layout, the ground plan described seems to have been too complex an entity for only a few men to set up quickly. In fact there is evidence suggesting that others were indeed involved.

As was indicated above, there was probably an augur involved on the administrative side, and from the mid second century B.C. onwards perhaps a praefectus fabrum too. ${ }^{52}$ Unfortunately, almost nothing is known about the development of this post before the mid first century B.C. so it is difficult to establish how, when, and / or why this office entered the Roman military administrative hierarchy.

On the actual construction side, there is evidence from Caesar's Gallic Wars that from at least the late Republic onward, the selection of a campsite and castramentation involved more than just a tribune and some centurions. ${ }^{53}$ It is difficult to say to what extent Caesar's remarks should be applied to the armies of an earlier period, but the evidence of the archaeological record from Spain argues heavily in favor of continuity over radical change. ${ }^{54}$ And even the ambiguous references in Polybius support this.

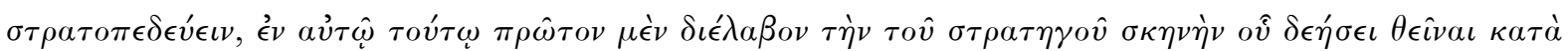

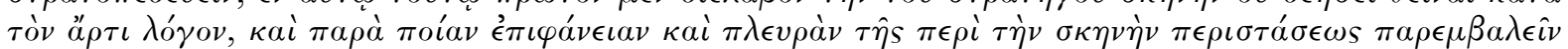

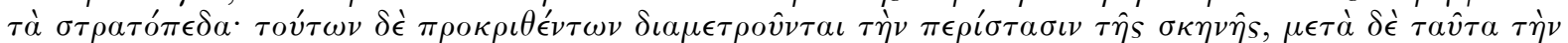

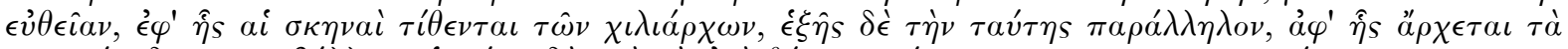

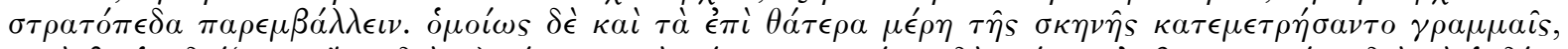

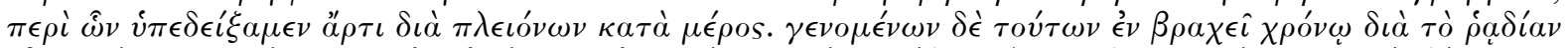

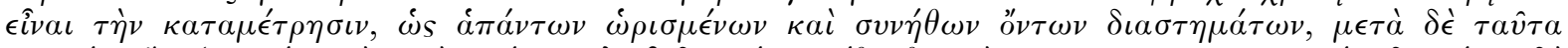

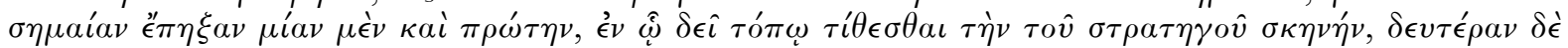

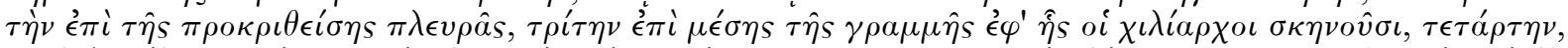

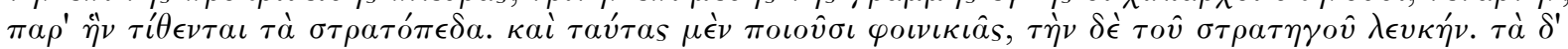

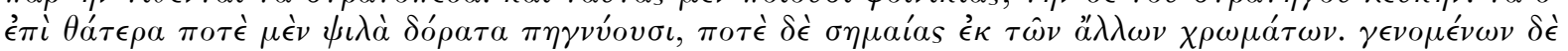

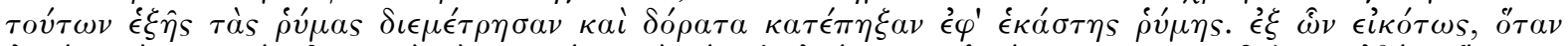

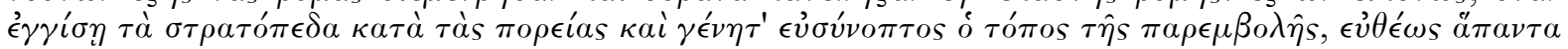

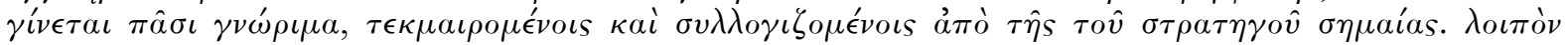

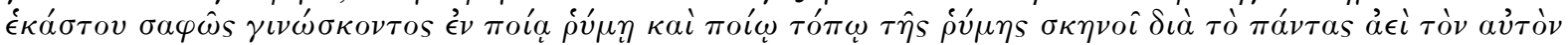

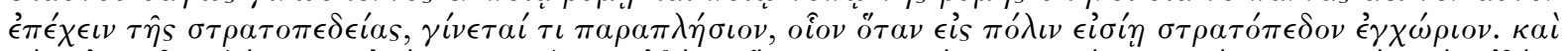

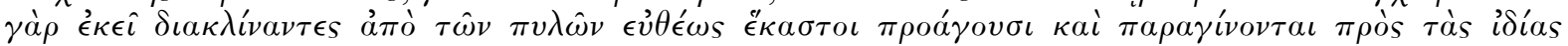

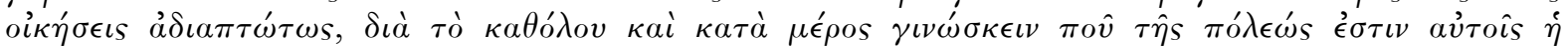

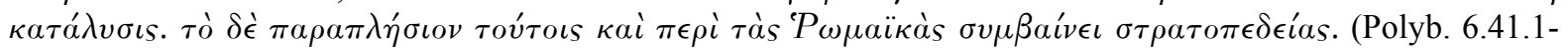
12).

${ }^{52}$ For references on the praefectus fabrum, see: Saddington 1996, 244 n.4; and Thomas 2004, 430 n.25.

${ }^{53}$ Compare Polyb. 6.40.4 and 6.41.1-2 with Caes. BG 2.17.1; Jos. BJ 3.115-119; 3.141; 5.47-52; Front. Strat. 2.7.12; and Veg. Mil. 2.7.6; 2.7.9; 3.8.3-4.

${ }^{54}$ On the subject of continuity see: Dobson 2008, 406-415 and Hanel 2007, 399-416. 
In a passage by Polybius he explains the organization used to construct the camp. When the passage is considered in connection with those quoted above, it would seem that similar systems were involved in layout and construction. Furthermore, as was shown in Chapter Two, the Imperial army possessed a similar hierarchy between the mensores and metatores, which may have evolved from the Republican system found here in Polybius:

Concerning the construction of the ditch and rampart, the two sides where the allies encamp fall to the lot of these units; the other two sides are assigned to the Romans, one to each legion. Dividing up the sections amongst the maniples, the centurions superintend while two of the tribunes make an inspection of the entire work. $^{55}$

Two tribunes with all the centurions oversaw all of the Roman maniples and allies constructing the castra, and perhaps a single tribune with some of the centurions, Roman soldiers and allies located and marked it out, an idea which seems to be very much in harmony with a statement found in Polybius' description of the Roman marching column:

So generally they marshal the extraordinarii to the vanguard; after these, the right wing of the allies is next in order; next after these follow the baggage train of the aforementioned follows. ${ }^{56}$

Taking all this evidence with the passage of Lucilius quoted at the opening of this chapter, it seems inevitable that the Roman army employed individuals out of the rank and file to mark out their castra, at least from the time of the Second Punic War. The last passage of Polybius quoted perhaps suggests that these mensores were drawn from the ranks of the evocati, who, as long-standing veterans, would have been well suited to the tasks of castramentation.

Such a conclusion draws out an important point. As evocati or ordinary milites the mensores must have been drawn from the ranks of the plebs. In the middle Republic, this would have meant that the mensores were in all practical terms more like the metatores of the Imperial period. This is to say that they would not have had access to the education necessary for them

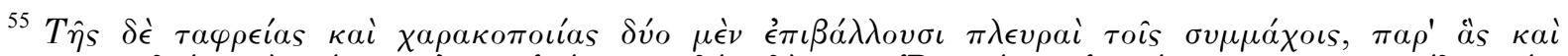

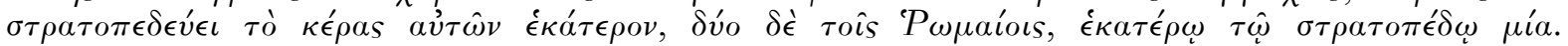

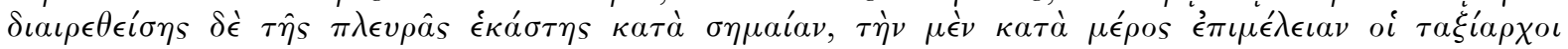

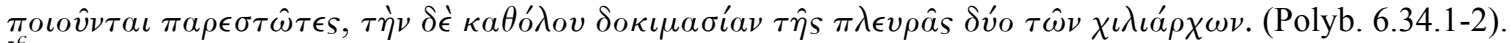

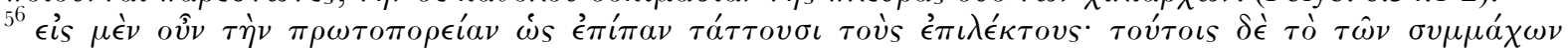

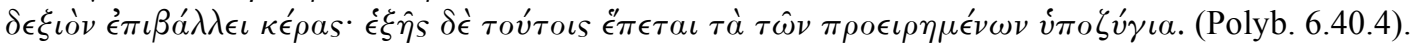


to practice the specialized technical and legal functions carried out by the agrimensores as discussed in the Corpus Agrimensorum. ${ }^{57}$ Indeed, if we take the evidence of Frontinus at face value, the terms mensor and metator may have been used interchangeably in the period before Sulla. ${ }^{58}$ Accepting such a fact, it is therefore necessary to now consider the sociological circumstances that would have caused the social and technical distinction observed elsewhere to take place. We will also consider the case study of L. Decidius Saxa, who may have been a surveyor, rising to prominence through the ranks of Julius Caesar's army.

\section{THE AGRIMENSORES IN THE FIRST CENTURY B.C.}

All the authors from the Republican period other than Lucilius who mention the mensores or other individuals who might have been mensores do so in the context of Caesar's Dictatorship, by which time the role of the mensores as independent experts on land law and surveying seems to have been firmly established. ${ }^{59}$ As a consequence, any attempt to trace the course of the mensores' evolution from enlisted men who marked out the castra to a semi-professional body must by necessity depend on inference, interpretation of selected texts, and circumstantial evidence. The very nature of such detective work means that any reconstruction presented will always be open to challenge. However, accepting that fact, there seem to have been two broad trends driving the transformation of the mensores. One was the increasing need for trained technicians within the ranks of the Roman army who could cope with the increasingly complex engineering problems the Romans faced in their military operations. As will be shown in the discussion of Saxa, this was particularly true in

\footnotetext{
${ }^{57}$ As Elaine Fantham points out in her recent article on Caesar as an intellectual, the higher education necessary for legal and intellectual pursuits could only be obtained through private tutelage at the end of the second century B.C. It is very unlikely that any lower class Romans could have afforded it even if they could find someone willing to do the teaching. Horsfall is almost certainly correct to see the education of the plebs as strictly oral during this period. For discussion see: Horsfall 2003; Fantham 2009,143-145.

${ }^{58} \mathrm{We}$ should not assume that Frontinus was using exact terminology reflecting the reality of Marius' world in the passage where he mentions the metatores. As Campbell pointed out in his 1987 article on military literature, Frontinus was writing a highly artistic text which reflected his antiquarian knowledge and which at best was intended to address contemporary military needs. As a consequence, Frontinus may have used contemporary Latin terminology to avoid confusing his audience. As a consequence, the term metator may not have come into usage until the mid first century B.C. See: TLL 8.878-879 where the earliest attested use of metator is in Cicero's Philippics. On the writings of Frontinus, see: Campbell 1987, 15, 17, 19-21; and Cuomo 2000, 189193.

${ }^{59}$ See: Lucil. Fr.100; Varr. RR 1.10.2; Cic. Phil. 11.12; 13.37; 14.10.
} 
the areas of road and bridge construction and in siege warfare. ${ }^{60}$ The second was the increasing inability or unwillingness of the Roman legal and governmental system to cope with the growing numbers of communities and / or individuals who needed to have issues of property ownership and / or land use adjudicated. In many ways, in a world where power and wealth were decided by the ownership of land, this latter issue was probably the more important of the two in terms of the mensores' development.

The events of the Social War are of particular concern for us here because they produced two important changes in the Roman landscape, which helped pave the way for the rise of the mensores as technical and legal experts. First, as Lavano speculates, the Social War almost certainly devastated the Roman world, destroying cities and agricultural land. ${ }^{61}$ There is no way for us to estimate the extent of the damage, though Strabo's description of Samnium in the Geographies may do some justice to the situation. ${ }^{62}$ Regardless of the details, it is probably safe to say that the war completely upset the established status quo of land tenure in the Italian peninsula.

Second, the Social War introduced a large body of new citizens to the Roman political and legal system. Such an admission meant that legal problems involving land tenure which would have been settled by local magistrates under tribal or at the least municipal laws could be brought to Rome and settled through the Roman court system. Bispham is probably correct in his summation of the fall-out from the Social Wars when he says that it took twenty years for the full effects of Italian enfranchisement to be felt in the Roman political and legal system. $^{63}$

When the Italians began to use the courts to sort out their problems in the mid $70 \mathrm{~s}$, the policies of Sulla's Dictatorship complicated matters, in respect to land ownership and litigation. When Sulla returned to Italy after his four-year operation in Asia against Mithridates, he began negotiating with the Italian allies to secure support for his march on

\footnotetext{
${ }^{60}$ On the Republican army's need to construct complex bridges quickly, see: Caes. $B G$ 4.17.3-10; 6.9.4; On the increasing complexity of siege works in the late Republic see: Caes. $B G$ 7.71-75 and compare the description of the Scipionic siege works at Numantia with those of Caesar at Alesia. See: Dobson 2008, 389-405; Davies 2006, 98-99, 103, and Plate 1 "Caesarian Siege System at Dyrrachium"; and Davies 2008, 702-704.

${ }^{61}$ Lovano $2002,18$.

${ }^{62}$ Str. Geog. 5.4.11. Strabo's description of Samnium has long been thought to have been an exaggeration reflecting Augustan or more likely Caesarian propaganda. For further notes on this see: Santangelo 2007, 143 n.31.

${ }^{63}$ Bispham 2008, 204.
} 
Rome. ${ }^{64}$ Most communities joined him, though places such as Pompeii resisted. When Sulla reached Rome and succeeded in subduing it, he instituted a program of punishments and rewards intended to shore up his faction in the Senate and stabilize the empire. The most important of these programs for this study was the rewarding of his allies by granting privileges to communities and the establishment of land grants for his veterans. However, in a departure from normal practice, Sulla established his veterans on individual assignments and in coloniae which were imposed on already existing communities. It is not known how many coloniae Sulla intended to establish, but the veterans came from 23 active legions and must have numbered into the tens of thousands. ${ }^{65}$ Archaeological, epigraphic, and literary evidence exists which firmly attests around a dozen settlement sites. ${ }^{66}$ The coloniae seem to have been established using the traditional system of triumviri and finitores, though we know the names of only two of the deductores who made up these commissions; L. Terentius Varro Lucullus who was deductor and patron of the colonia at Praeneste and P. Cornelius Sulla who was deductor and patron of the colonia at Pompeii. ${ }^{67}$ The changes implemented by Sulla, altered land tenure and ultimately encouraged specialists in land law and surveying.

Evidence found in Cicero's Pro Caecina, Pro Tullio, Pro Sulla, the four speeches delivered against Catilina, and the three speeches concerning the Rullan land law all reflect the problems that the Social War and Sulla's settlement program caused in relation to land ownership. The Pro Tullio, which probably dates to between 75 and 71 B.C., is particularly instructive for our purposes. ${ }^{68}$

While these passages are badly fragmented, they provide a glimpse into a private dispute between two Romans over boundaries at a remote community in South-Eastern Italy. Marcus Tullius seems to have been a hereditary landowner of the colonia Thurii: "Fundum habet in agro thurino M. Tullius paternum." Between his farm and one which belonged to a member

\footnotetext{
${ }^{64}$ See: Santangelo 2007, 72-75

${ }^{65}$ App. $B C$ 1.100; 1.104 .

${ }^{66}$ For the evidence see: App. BC 1.89.408-412; Flor. 2.9.27; Plin. NH 3.52, 80; 14.62; Cic. Mur. 24.49; Cic. Sull. 60-62; Cic. In Cat. 1.3.8; Cic. De Leg. Agr. 2.78; Sall. Hist. 3.97; Lib. Col. 180.1; 180.19-20; 180.25-28; 182.5; $182.8 ; 182.35 ; 184.18 ;$ CIL 10.3764; 10.3765; 10.3832; 11.1210; 11.6675; 14.2978; 14.2979; AE 1991.518; concisely discussed with a lot of other evidence by Santangelo 2007, 147-157; and by Bispham 2008, 447-456. Bispham's discussion is principally focused on the administrative structure of the municipia where coloniae Sullae were established and where both administrative systems coexisted for a time. It is an interesting close examination of the evidence and will receive further attention below.

${ }^{67}$ See: Cic. Sull. 60-62 and Santangelo 2007, 141-2 for the evidence on these two deductores.

${ }^{68}$ For the dates of the Pro Tullio and the Pro Caecina, see: Lintott 2008, 80. For an analytical discussion of the speech, see: Lintott 2008, 69-73.
} 
of the senatorial Claudii was another piece of land which is referred to as the centuria Populiana. As Andrew Lintott so rightly pointed out recently, this piece of land was probably at one time the farmstead of a Roman military veteran named Populianus. ${ }^{69}$ At some point, probably in the last decades of the second century B.C., Tullius' father or grandfather acquired the land, perhaps when the owner died without issue.

Cicero explains in the speech that Gaius Claudius had sold his farm, which neighbored the centuria Populiana, to Publius Fabius, who was presumably part of the large hereditary clan of Fabii at Rome. Apparently Fabius and his financial partner made a bad deal and bought a farm, which was in a bad state of repair with its buildings burnt down and its fields uncultivated..$^{70}$ Regretting his investment, Fabius attempted to sell his property and included the centuria Populiana when he posted his advertisement. Whether his actions were due to ignorance or greed cannot be established, though the latter seems more likely. Regardless, Tullius learned of Fabius' actions and demanded that he make a declaration of what he thought the boundaries of his land should be in the presence of Tullius' representative and an independent procurator, who was presumably employed by the community of Thurii. Fabius failed to do this and sent an armed gang from Rome through the neighborhood to intimidate those who might interfere with what he was doing. Violence ensued, and Tullius, who had intended to sue Fabius for a property violation, ended up suing Fabius for the murder of some of his slaves. ${ }^{71}$

The actual speech Cicero gave at the trial of M. Tullius is of less interest here than the system he described for resolving the initial boundary dispute. From the text of his speech as it stands, it would seem that there was an existing custom which required anyone selling land to describe or render an accounting of its boundaries to a potential buyer:

But his authority had not yet demonstrated the boundaries. Tullius sent letters to the procurator and to his estate manager... Fabius denied that it had to be done. He gave an account of the boundaries to Acerrionus while the procurator and

\footnotetext{
${ }^{69}$ Lintott 2008, 69, n.2.

${ }^{70}$ Lintott 2008 69, n.1 maintains that the destruction was the result of the Social War and cites Cic. Tull. 13-16 as proof of this. However, the sections in question do not directly state that the fundus Claudii was destroyed in the Social War. It is equally possible that the destruction of this farm could date to the revolt of Spartacus as Lintott himself admits elsewhere. Even with such ambiguity, the date Lintott assigns to the speech, 72 B.C. is probably correct. It certainly took place after 76 B.C. and before 68 B.C. as internal evidence cited by Lintott shows. See: Lintott 2008, 73 n.10 for details.

${ }^{71}$ Cic. Tull. 21-23.
} 
manager were absent and has not yet handed over the Popilian century as freehold. $^{72}$

Furthermore, it would seem that neighbours could be present for such an accounting and could challenge the seller's account. In such a situation, it would seem that an impartial observer or judge was brought in to adjudicate the dispute. In the case of Marcus Tullius, he called in a procurator: mittit ad procuratorem litteras...

The custom of demonstrare as a means for resolving property disputes for the Romans themselves may date back to the mid third century B.C. ${ }^{73}$ If the custom did indeed date back that far, then it seems likely that there was a religious ritual associated with it and that most Romans were aware of what that ritual formula involved. ${ }^{74}$ Evidence of this ritual formula suggests that specialists (i.e: mensores) did not yet exist.

The presence of the procurator demonstrates this point. A procurator was not an expert on Roman religion or on land law; he was an administrative or financial officer. This suggests that in the period down to the time of Spartacus' Revolt, anyone who could read, consult local records, knew something about the law, and was trusted by both parties could act as arbitrator. However, such a fact does not prove that specialists on land law and surveying were not beginning to have a presence in the Italian landscape in the period after Sulla's death. Their absence in this situation merely indicates that Tullius did not have access to them or felt that they were not necessary. It is quite possible that they were available, but few and far between, and as a consequence only employed to cope with particularly important

\footnotetext{
${ }^{72}$ Nequedum finis auctor demonstraverat. mittit ad procuratorem litteras et ad vilicum Tullius... facturum negavit; illis absentibus finis Acerronio demonstravit neque tamen hanc centuriam Populianam vacuam tradidit. (Cic. Tull. 17).

${ }^{73}$ As was mentioned above, archaeology may be changing our understanding of Roman settlement patterns in the period before the Second Punic War and as a consequence it seems dangerous to push customs involving property ownership back before this date. However evidence from Plautus and Cato the Elder indicates that property boundaries were needed in the second century B.C. and if boundaries were needed, it seems a fair deduction that there were property disputes and a means of resolving them. See: Plaut. Poen. 48-49; Cat. De Agr. 1.7; 6.3. This argument receives some support from Cicero's speech on the Agrarian Law of Rullus, where Cicero states that the Twelve Tables provided a means for private citizens to bring an action against one another for property violations. Such a remark is suspicious given the varied uses to which Roman politicians put such ancestral claims in the late Republic. Even so, see: Cic. De Leg. Agr. 1.55. For further discussion of this point, see: Gargola 1995, 201 n.33.

${ }^{74}$ This is in part indicated by the fact that passages from Cato the Elder's Manual on Agriculture show that early Roman rituals were intended for ordinary people to perform under ordinary circumstances, and partly by the association between boundaries and the god Terminus. See: Cat. De Agr. 131-132, 134, which describe a preharvest ritual called porca Praecidanea; 139 and 141 which describe a ritual for purifying land called the suovetaurilia; and see: Gargola 1995, 33, 201 n.40.
} 
matters or situations where the legal issues were too complicated for those who normally practiced Roman law.

Two other situations in the period between Sulla's death and the consulship of Caesar highlight the circumstances which may have led to the rise of the mensores as legal and technical experts on land holding. One is the long-running series of problems involving the Etruscan communities of Faesulae, Arretrium, and Volaterrae. The other the internal conflict between the Oscan and Greek inhabitants of Pompeii and the Sullan veterans settled there after the civil war. The first of these two situations is much harder to document and understand, as our sources for it are so fragmentary. However, it would seem that the Etruscan municipia were die-hard supporters of Marius. To pacify and make an example of them Sulla established coloniae. In the case of Faesulae the local inhabitants rebelled, broke into the fortified compounds where the colonists were living, and reclaimed their land.

The Faesulanians broke into the fortified houses of the Sullan veterans and after many of them were cut down, they recovered their land. And they defended their actions in the Senate on the grounds that the rural population was being forced from their homes and into exile. And the consuls, when an army was given to them, set out into Etruria as the Senate ordered.... ${ }^{75}$

The exact cause of the revolt is unknown. Cultural friction is an unlikely cause since archaeological and epigraphic evidence shows that the Etruscan municipia had been freely adopting Roman cultural practices since the late third century. ${ }^{76}$ The main source of contention seems to have been the manner in which the deductores went about appropriating land and redistributing it to the colonists. ${ }^{77}$ The citizens' grievances were no doubt partially fuelled by the loss of their property and their general dislike of Sulla. ${ }^{78}$ However, there may

\footnotetext{
${ }^{75}$ Faesulani irruperunt in castella ueteranorum Sullanorum et compluribus occisis agros suos receperunt. et in senatu defendebant, quod uulgus agreste domoque extorre eo coactum esset. et consules dato exercitu in Etruriam profecti sunt, ut scitum (...). Licin. 36.36.

${ }^{76}$ See fundamentally: Munzi 2001, 47-52; and Benelli 2001, 11-15. Bispham has recently pointed out that throughout most of the period from the Social War to the age of Augustus, the Roman state took a disinterested and non-interventionist approach to the cities of Italy, an attitude which was a sharp contrast to the cities in the rest of the empire. See: Bispham 2008, 416-417.

${ }^{77}$ Licin. 36.36-37 and see the discussion by Santangelo 2007, 181, n.36.

${ }^{78}$ Max Weber in 1895 noted the importance attached to land-ownership and its relationship to political power in the ancient world. In a world where one's ability to produce food equated to economic security such a relationship would seem fundamental. In stripping a hostile group of their land, Sulla was stripping them of not only political power, but of economic security as well. Modern scholars seem to overlook this at times when considering the problems involving Sulla's colonial program and thus miss what may have been the main source of tension between the colonists and local population. For Weber's remarks, see: Weber 2008, 38-51, 61-66, \& 70-76.
} 
have been more complex issues involved, which were tied to local religious laws on boundaries and property ownership, which the deductores failed to understand in appropriating and distributing land to individual colonists. ${ }^{79}$

Whatever the circumstances were, Sulla seems to have recognized the problem since he did not finish assigning colonists to the colonia at Arretrium, and never assigned the land confiscated from Volaterrae at all. ${ }^{80}$ In the case of Volaterrae, Sulla attempted to extract a unique punishment by depriving the citizens of Roman citizenship, a move probably reflecting both Volaterrae's stubborn resistance and Sulla's own recognition of problems with the colonial program in Etruria. ${ }^{81}$ His attempt to revoke citizenship was a controversial move and patrons of the city such as Cicero successfully argued that it was illegal. ${ }^{82}$

After the revolt at Faesulae was suppressed, the Senate at Rome seems to have done little to resolve the tensions in the community. This was probably due to the controversial nature of the Sullan colonial program, though there may have been other external factors as well. ${ }^{83}$

There is some evidence that one or more popularist politicians attempted to resolve the situation unsuccessfully in 70 B.C. and that the Rullan law of 63 B.C. was in part intended to address the rights of the Sullan veterans of Etruria. ${ }^{84}$ If the latter was true, then by preventing

\footnotetext{
${ }^{79}$ In spite of two recent examinations of Etruscan concepts of space, we still do not have a full understanding of how Etruscan spatial delineation differed from that of the Romans or how those differences developed under the influence of Roman culture from the third to the first century B.C. An Etruscan boundary stone from the second century, which has some similarities to the Lapis Niger found at Rome indicates an exchange of ideas between the two cultures, but it also suggests strong differences when it is compared to examples of Roman boundary stones. For a list of Roman boundary stones in CIL, see: Campbell 2000, 452-454. For the Etruscan boundary stone see: Edloud-Berry 2006, 119 FIG. 3. For the most recent examination of Etruscan spatial concepts, see: Briquel 2008, 121-133.

${ }^{80}$ See: Plin. NH 3.52; Cic. Ad Att. 1.19.4; CIL 11.6675.

${ }^{81}$ Cic. Rosc. Am. 7.20; Licin. 36.8.

${ }^{82}$ Cic. Ad Att. 1.19.4; Cic. Dom. 30.79. The issue of citizenship for the people of Volaterrae along with the legality of Sulla's program in general were key elements in Cicero's speech on behalf of Caecina in 69 B.C. See: Frier 1985, 19-27, 42-47, and 99-103; along with Santangelo 2007, 175-178; and Lintott 2008, 73-80 for further discussion.

${ }^{83}$ On the controversial nature of the Sullan reforms, see: Drummond 2000, 128-130. Other factors, which may have influenced inaction over the fate of the colonists at Faesulae, may have included competition between Roman notables who were patrons of the individual municipia; the war with Sertorius; on-going problems in the East with Mithridates; and an endemic problem with piracy which was threatening the Roman grain supply. On the relationship between individual Roman nobiles and the municipia, see: Bispham 2008, 403-405, \& 457-461. On the war with Sertorius, the best treatment is probably: Konrad 1994. On the problems with Mithridates, the most recent treatment is: Maor 2010, which I regret I have not been able to properly examine. And on the problem of piracy at this time, see: De Souza 1999, 158-178.

${ }^{84}$ See: Cic. Ad Att. 1.18.6; 1.19.4; De Leg. Agr. 3.4; 3.6; 3.7; 3.11; Drummond 2000, 135-137; and Lintott 2008, 136-142. It is interesting that Lintott does not cite Drummond's article in the context of his discussion of the De Lege Agraria. His failure to do so may explain why there is no extensive examination of the relationship
} 
its passage, Cicero either inadvertently or deliberately drove the veterans who had lost their lands into the arms of disaffected men such as Manlius and Catilina. ${ }^{85}$ The following passage is important since it shows that people seeking a legal solution to property disputes at Rome were often frustrated by Roman politics. I would argue that this frustration eventually drove the development of the role of the mensor as an independent and impartial arbitrator.

...meanwhile, they see that Catilina is active and prosperous, surrounded by a multitude of young equites, secured behind a bulwark of spies and assassins, inflated by the hopes of the soldiery, and by, as he himself has said, the promises of my colleague, inundated by a flock of colonists from Arretrium and Faesulae, a mob which is distinguished by a different sort of people, men struck down by the calamity in the time of Sulla. ${ }^{86}$

The related events in Etruria demonstrate how fluid political relationships were in the Late Republic and the extent to which the complexities of property disputes could grow if left to fester. The passage from Cicero's Pro Murena, cited here clearly shows the veteran Sullani making common cause with those who had also lost land to Sulla, a group who were hostile to the colonists only fifteen years earlier. It may be presumed that their common grievance was that both had lost property and were having a difficult time obtaining their rights at Rome. Under such circumstances, it would probably have been quite natural for both parties to turn to any source of assistance, since there does not seem to be any evidence for the involvement of agrimensores up to 63 B.C. A passage of Sallust's Bellum Catilinae suggests that Catilina may have been one such source. If he was, then Cicero and other hostile sources may have used the relationship to paint Catilina as a dangerous rebel conspiring to overthrow the res publica.

Trusting in these friends and associates, Catilina, in part because there was a great deal of debt through out the land and in part because many of the Sullan soldiers having used up the greater part of their own resources, remembering the plunder

\footnotetext{
between the Rullan land legislation in 63 B.C. and the insurrection of Manlius in conjunction with Catilina later that same year. Drummond's article makes such a study possible. However this cannot be properly undertaken here.

${ }^{85}$ Andrew Drummond makes the following interesting observation in regard to Cicero's actions against Rullus and Catilina: "Rather than engage in principled opposition to land allocation (or popularis proposals) as such, Cicero consistently attempts to outflank his adversaries by stealing their political clothes."(Drummond 2000, 126). Andrew Lintott makes a similar and perhaps independent remark at: Lintott 2008, 138.

${ }^{86}$ Catilinam interea alacrem atque laetum, stipatum choro iuventutis, vallatum indicibus atque sicariis, inflatum cum spe militum <tum> conlegae mei, quem ad modum dicebat ipse, promissis, circumfluentem colonorum Arretinorum et Faesulanorum exercitu; quam turbam dissimillimo ex genere distinguebant homines perculsi Sullani temporis calamitate. (Cic. Mur. 49).
} 
and victories of long ago, longed for a civil war, hatched a plot to utterly overthrow the Republic. ${ }^{87}$

A further passage from Sallust along with two sections from Cicero's second speech against Catilina indicate that the alliance between the colonists, citizens, country folk, and Catilina himself was probably the doing of a centurion named Manlius, In the absence of impartial specialists, they felt that they collectively had to take matters into their own hands. These passages also suggest that the situation may have been far more complex than most scholars recognize, with veteran colonists acquiring land from their fellows as much as the native citizens of the municipia.

As a matter of fact, it is my conviction, that the centurion Manlius set up a camp in the territory of Faesulae to wage war against the Roman people in his own name... ${ }^{88}$

Meanwhile, Manlius was in Etruria stirring up the plebs, who were longing for a revolution on account of their poverty and anger over an injustice, because each lost their land and all good things under the domination of Sulla. In addition, he picked up brigands of every sort who were numerous in the region, and not a few fellows from the Sullan colonies, for whom wantonness and luxury had left nothing from their great plunder. ${ }^{89}$

There is a third class of men afflicted by old age, but robust from physical training. That Manlius from whom Catalina is now taking up command is from this class. These men are from the colonies, which Sulla established, which I recognize are entirely composed of the best citizens and the bravest of men. But even so, there are colonists who through unexpected and sudden wealth have most lavishly and arrogantly inflated their own importance. These men, while they were building like the rich, enjoying choice properties, large households, and sumptuous parties, were nevertheless getting themselves into debt... ${ }^{90}$

\footnotetext{
${ }^{87}$ His amicis sociisque confisus Catilina, simul quod aes alienum per omnis terras ingens erat et quod plerique Sullani milites largius suo usi rapinarum et victoriae veteris memores civile bellum exoptabant, opprimundae rei publicae consilium cepit. (Sall. $B C$ 16.4).

${ }^{88}$ Etenim, credo, Manlius iste centurio, qui in agro Faesulano castra posuit bellum populo Romano suo nomine indixit... (Cic. In Cat. 2.6.14).

89 Interea Manlius in Etruria plebem sollicitare egestate simul ac dolore iniuriae novarum rerum cupidam, quod Sullae dominatione agros bonaque omnis amiserat, praeterea latrones cuiusque generis, quorum in ea regione magna copia erat, nonnullos ex Sullanis coloniis, quibus lubido atque luxuria ex magnis rapinis nihil reliqui fecerat. (Sall. $B C 28.4$ ).

${ }^{90}$ Tertium genus est aetate iam adfectum, sed tamen exercitatione robustum; quo ex genere iste est Manlius, cui nunc Catilina succedit. Hi sunt homines ex iis coloniis, quas Sulla constituit; quas ego universas civium esse optimorum et fortissimorum virorum sentio, sed tamen ii sunt coloni, qui se in insperatis ac repentinis pecuniis sumptuosius insolentiusque iactarunt. Hi dum aedificant tamquam beati, dum praediis lectis, familiis magnis, conviviis apparatis delectantur, in tantum aes alienum inciderunt... (Cic. In Cat. 2.9.20).
} 
What the situations at Faesulae and Arretrium both show is the complex, and combustible political reality that Sulla produced in establishing two separate political polities in the same physical space. A group of well-trained agrimensores acting with the authority of the communities' patrons could have probably sorted out many of the problems had they been brought in early enough in the dispute. The fact that agrimensores were not involved in the problems involving Arretrium and Faesulae prior to the revolt of Manlius and Catilina might suggest to some that the agrimensores did not yet exist as technical specialists in the period before 63 B.C. However, such a conclusion should be approached with care since it is quite possible that they did exist and that the patrons of these respective communities either chose not to make use of the mensores' services or else the patrons did not have access to them. It is important to bear this fact in mind, along with the complexity of land holding and politics in these communities, as we turn our attention to southern Italy.

Southern Italy was on the whole far less hostile to Sulla than was the North. Even so, he established a number of coloniae. Like Faesulae and Arretrium, many of these coloniae seem to have been double communities, and like Faesulae and Arretrium the southern coloniae seem to have had their fair share of problems. However, there was an important difference. As far as can be ascertained, the southern coloniae and municipia did not turn to open violence to solve their problems. This does not mean that things were calm, but it does mean that the communities of southern Italy found a way to manage their problems in a far more constructive manner, which I contend, included the involvement of mensores. Establishing the exact details of how this was accomplished is not easy since the only community we know anything about is Pompeii. However, the available evidence on that city's problems is interesting and instructive, albeit disputed. The evidence for the conflict between the colonists and native citizens is exclusively preserved in passages of Cicero's speech in defense of Publius Sulla the year after the revolt of Catilina and Manlius. This text shows that at least in Campania the communities had begun to employ the services of an impartial arbitrator, unlike the cities of Etruria.

In the first place, the entire dispute between the Pompeiani and the colonists was entrusted to their patrons, since it was a long-standing affair and had been carried on for many years. Then, the matter was investigated by the patrons in such a manner that Sulla did not disagree with the opinions of the others in the matter... Equally eager, the Pompeiani, who are also named in the indictment by the prosecutors, are also present; though they disagreed with the colonists about the 
canvassing and about their own voting, they agree about the well being of the community. ${ }^{91}$

From this passage, it would seem that Pompeii like Faesulae was established as a double community by Sulla. This meant that two separate political bodies existed within more or less the same physical space with the Sullan veterans living with a colonial government and the Pompeiani having a municipal government. ${ }^{92}$ The Pompeiani were probably at a political disadvantage and enjoyed far fewer privileges than the colonists, and as a consequence many of the problems that existed at Faesulae and Arretrium also existed at Pompeii. It is not clear as to whether the veterans lived outside the central city while the municipal citizens lived inside as seems to have been the case at Faesulae, but many scholars postulate that this was the situation at least in the early days of the colonia.$^{93}$ Regardless, there seems to have been a good deal of concern amongst Roman politicians that the problems generating the revolt of Manlius and Catilina would ripple out to affect Pompeii too. This concern seems to have been so great that that a group of politicians used it as the basis of a political prosecution directed against Publius Sulla the year after the Catilinarian conspiracy was crushed.

Evidence for this prosecution seems to have been drawn from Publius Sulla's involvement in the resolution of a dispute between the Sullan colonists at Pompeii and the native Pompeiani. The only evidence on the exact details of the dispute comes from the cryptic remarks Cicero made in his speech. From these remarks, it would seem that there was a long running fight between the two groups in the community over ambulatio and suffragia. Scholars have disputed the exact meaning of these two words for five centuries. The argument tends to be broken down into two camps, the political and the spatial. ${ }^{94}$ The first group argues that the term ambulatio has to be interpreted as referring to the canvassing for votes because of the strong conjunction $a c$ and because of the political context generated by suffragia. The second school of thought points out that ambulatione has no known political meaning in and of itself and therefore cannot be understood in the sense of "canvassing", but must rather have a metaphorical meaning involving space. The second school further points out that the word

\footnotetext{
${ }^{91}$ primum omnis Pompeianorum colonorumque dissensio delata ad patronos est, cum iam inveterasset ac multos annos esset agitata; deinde ita a patronis res cognita est ut nulla in re a ceterorum sententiis Sulla dissenserit;... adsunt pari studio Pompeiani, qui ab istis etiam in crimen vocantur; qui ita de ambulatione ac de suffragiis suis cum colonis dissenserunt ut idem de communi salute sentirent. (Cic. Sull. 60-62)

${ }_{92}$ For further evidence of the identity of Pompeii as a duel municipia and colonia, compare Cic. Sull. 60-62 with Plin. NH 2.137; 3.62; 14.38 \& 31.94; and consult Bispham 2008, 447-449.

${ }^{93}$ See: Santangelo 2007, 158-163.

${ }^{94}$ For a fuller discussion of these two schools of thought complete with bibliography, see: Bispham 2008, 449450 .
} 
ambulatio can mean either the act of strolling or a portico. ${ }^{95}$ And while the second meaning of the word has had its proponents, the context in Cicero's speech quoted here does not seem to make it likely.

Both schools fail to recognize that neither explanation is mutually exclusive of the other. Cicero was often cryptic when it suited his purposes and many passages of his speeches are capable of multiple interpretations. In addition to this, both schools of thought overlook the fundamental fact that politics, like most aspects of Roman life, was generally played out in a specific spatial and temporal context. ${ }^{96}$ This means that the term ambulatio in the context of the Pro Sulla could carry both spatial and political connotations unique to this particular speech.

As Bispham argued in 2008, the term ambulatio certainly carries a sense of movement, space, and the concept of physical access to topographical locations. ${ }^{97}$ Because of this, it seems fairly certain that one of the grievances of the Pompeiani was that they were being denied access to specific places within the city. However, this does not push the interpretation of the term far enough since it does not take account of the strong conjunction in $a c$, which Cicero used to join his concepts. The use of this conjunction, taken with the phrase de suffragiis provides a political context, which suggests that the Pompeiani were being denied access to specific regions not just on a day to day basis, but in the more important context of running for public office and the electoral process.

Based on this evidence and the problems observed in connection with Faesulae, I would argue that the founders of the colonia at Pompeii established two parallel constitutions, one for the colonia and one for the municipia. The colonial charter prevented the Pompeiani from canvassing for votes in any district set aside for the colonists. Furthermore, it is likely that the

\footnotetext{
${ }^{95}$ Bispham points out that Cicero used ambulatio in both senses, but only in an architectural sense within the context of his speeches. In the political dialogues, the sense of walking or strolling predominates; typically in the context of political discourse. He also remarks that the singular nature of ambulatio suggests that it had a separate identity from that of suffragia, and could refer to spatial access via walking or to a physical structure. As he also notes, there are several porticoes in Pompeii that the word could reflect if they were involved in voting. I do not consider these points to be particularly significant in light of the over-all language and context of the passage; however, see: Bispham 2008, 449-451.

${ }^{96}$ For the importance of space to the political activities of the Romans as well as to cultural identity, see particularly the full-length study in Sumi 2005, where the author carefully dissects the relationship between political ceremony and public space. More generally, see: Gargola 1995, 12-31; and Wallace-Hadrill 2008, 171$178,259-275$.

${ }^{97}$ Bispham 2008, 450-451.
} 
Pompeiani were forbidden to enter or use public buildings such as the new amphitheatre constructed specifically for the veterans' use. ${ }^{98}$ It also seems likely that the colonists were not restricted as to where they could canvass, and that when it came to voting, the Pompeiani were either disenfranchised in some way or else were handicapped so that their votes did not count as much. Such restrictions would have been an increasing nuisance to the original citizens of Pompeii as time went on and colonists acquired new property, sold their allotments to relocate, or married into local families. Such activities would have seen the colonists and citizens move into areas not originally set aside for them and any attempt to enforce the original regulations would have run into problems. However, rather than resort to open violence to settle their problems, Cicero asserts that both groups were united in their concern for the welfare of Pompeii and thus in the end submitted their differences to the arbitration of the colonial patrons. It is unclear how P. Sulla and the other two unnamed deductores coloniae went about resolving the problem. It would seem that even Sulla who seems to have enjoyed good relations with the Pompeiani could have been accused of bias in favour of one party or the other. Still, Cicero asserted that the three were in agreement as to how the problem was to be resolved, and Cicero's use of the perfect tense in describing the conflict suggests that it had been, though the fact that the colonists and Pompeiani were present at the trial of Sulla in two separate contingents suggests that there were still some unresolved issues between the two parties. The logical explanation as to how the deductores could have resolved the conflict was for Sulla and the others to call in an unbiased, nonpartisan agent who was approved by both parties to redistrict and reorganize the electoral system. Such a job would have required knowledge of both law and surveying as well as a considerable reputation for honesty. It is both interesting and fortunate that some circumstantial epigraphic evidence survives to indicate that such individuals did exist and were operating in Campania near to Pompeii. This evidence probably reflects both Sullan and Caesarian efforts to reorganize the public land in the Ager Campanus and as such deserves some consideration, since it dates the employment of independent surveyors in the establishment of municipal boundaries.

\footnotetext{
${ }^{98}$ See: Santangelo 2007, 158-165.
} 
Lucius Soranus son of Lucius, Lucius Arrius son of Marcus, Praetorial Quattuorviri, saw to it that a boundary was established in accord with the Senate's decree. $^{99}$

The exact providence of this inscription is not known, however Mommsen assigned it to the municipia of Cales and there does not seem to be any reason to doubt this attribution. ${ }^{100}$ Bispham, after a full study of the quattuorviral magistracy, assigned the inscription a date of after 70 B.C. ${ }^{101}$ The fact that the inscription makes no mention of Caesar as dictator nor of the Second Triumvirate, nor of any imperial magistrate suggests that it also predates 49 B.C. as it is unlikely that the dictator or his successors would allow a municipium to unilaterally establish a boundary without reference to them.

The general absence of evidence for large-scale redistricting and the problems at Faesulae, Arretrium, and Pompeii during the mid 60s make it unlikely that the redistricting described in the inscription took place before 60 B.C. As a consequence, the most likely time for the activities of Soranus and Arrius was the period immediately after the passage of the Lex Julia in 59 B.C. or the Lex Mamilia in 55 B.C.$^{102}$ The unilateral nature of the boundary shows that it was established between the municipia and some section of public land, probably the Campus Stellas.

Regardless of the cause for the boundary's establishment, the formula used by Soranus and Arrius closely matches that found on imperial boundary dedications in which the emperor seems to have taken credit for work carried out by professional mensores. ${ }^{103}$ The use of the

\footnotetext{
${ }^{99}$ L(ucius) Sora(nus) L(ucii) F(ilus) / L(ucius) Arrius M(arci) F(ilus) / IIII uir(i) Pr(aetores) D(e) S(enatu) S(ententia) / term (inandum) c(urauere). (CIL 12.1574). Bispham feels that Pr(aetores) may also be expanded as $\operatorname{Pr}$ (aefecti), and he may well be right. However, I have retained $\operatorname{Pr}$ (aetores) because there are other instances where municipia or coloniae were governed by praetors. Bispham also notes the over all uniqueness of this inscription. See: Bispham 2008, 364

${ }^{100}$ The fact that this inscription seems to have been found on the edge of Calene territory near to the Campus Stellas and then taken to the church of St. Maria supports Cales as the point of origin. In addition, the presence of the letters D. S. S. argue for a Calene origin since other inscriptions from that city also mention a senate. It is perhaps of interest that the Rullan law of 63 B.C seems to have called for the distribution of both the Campus Stellas and the Ager Campanus. It is likely that Caesar's legislation of 59 B.C. covered a reorganization of the Campus Stellas while exempting the Ager Campanus. On these points, compare: CIL 10.3917; 10.3923; 12.1574; 12.3118; and AE 1989.176. On the division and location of the Ager Campanus and the Campus Stellas, see: Cic. De Leg. Agr. 1.19-20; Cic. Ad Att. 1.19.4; and Talbert 2000, Map No. 44.

${ }^{101}$ Bispham 2008, 365.

102 On these laws see: Crawford \& Cloud 1996, 763-766; and Bispham 2008, 210, n.23. Bispham discusses the development of municipal charters and incorporates the Lex Mamilia and Lex Iulia Agraria into his discussion, providing an interesting context for them. See: Bispham 2008, 205-246 for his full analysis.

${ }^{103}$ By way of example, compare CIL 12.1574 with the imperial activities described in CIL 10.2838. For evidence that mensores were active as surveyors under both Caesar and Augustus see: Varr. RR 1.1.10; and CIL
} 
verb curare in the inscription further suggests the act of organizing or supervising work carried out by others. Both facts strongly suggest that a professional mensor or mensores were responsible for the establishment of the boundary decreed by the Senate of Cales. If this assessment is correct, then it seems that mensores were active by the mid 50s B.C. and may well have been responsible for sorting out the problems at Pompeii.

One document supporting this argument, often overlooked, is the lex Iulia Agraria. Three fragments of this law have survived under the title of the lex Mamilia Roscia Peducaea Alliena Fabia. Michael Crawford has given the text of these laws considerable study, and his arguments in favor of the proper identity of the text of the lex are convincing and once again illustrates the role of independent surveyors. ${ }^{104}$

Chapter $\mathrm{V}$ of the statute. Whoever shall have founded a colony or constituted a municipium, prefecture, forum or conciliabulum according to this statute, he is to see that boundaries and decumani be drawn and boundary markers be set up on that land, which shall be within the boundaries of that colony, municipium, forum, conciliabulum or prefecture; and whatever boundaries he shall have established in this way, they are to be their boundaries, provided that he do not draw boundaries outside the colonial land or the territory; and whatever boundary markers shall have been set up according to this statute, no-one is to overthrow or move from its place any of them knowingly with wrongful deceit... ${ }^{105}$

The text of the fragment of the lex as it is produced here, is of particular interest in the context of this study for three reasons. First, the law seems to institutionalize the system of arbitration and prosecution used for dealing with a disputed boundary. The law suggests that such a system existed by right of custom but not a formal legal institution. Second, other portions of the law, not reproduced here, specifically make reference to the restoration and preservation of boundary stones by individual property owners. Such a legal proscription suggests that the manipulation of boundary markers, or their neglect, formed a major part of the problems in the period before Caesar's consulship. It is perhaps of some interest that mensores are not mentioned in connection with this, but it should be remembered that the

\footnotetext{
$1.1109=1.1423$.

${ }^{104}$ For bibliography see: Crawford \& Clowd 1996, 763.

${ }^{105} \mathrm{~K}$ (aput) l(egis) V. Qui hac lege coloniam deduxerit, municipium praefecturam forum conciliabulum constituerit, in eo agro, qui ager intra fines eius coloniae municipii fori conciliabuli praefecturae erit, limites decumanique ut fiant terminique statuantur curato; quosque fines ita statuerit, ii fines eorum sunto, dum ne extra agrum colonicum territorium fines ducat; quique termini hac lege statuti erunt, ne quis eorum quem eicito neue loco moueto sciens dolo malo... (lex Iul. Agr.). Text and translation is that of Michael Crawford. See: Crawford \& Clowd 1996, 763-764.
} 
Corpus Agrimensorum likewise refers to the establishment of boundary stones without special reference to a mensor. ${ }^{106}$ As a consequence, the absence of mensores from the text of the law should probably not be regarded as significant. Indeed, the third and final point of interest is the text's language. This language strongly suggests that mensores were recognized as an active part of the Roman legal landscape, though they may not have operated under that name in 59 B.C.

The linguistic aspect of the text that is of interest here is the fact that every time Caesar refers to the foundation of a colonia or municipia he uses the singular form of the verbs. This singular form indicates an individual acting as a colonial deductor. As has been noted elsewhere, the usual organization for the foundation of a colonia under the Republic was the triumviri or board of three. ${ }^{107}$ A single deductor with a mensor or small group of mensores was the normal method of founding a colonia under the empire. ${ }^{108}$ Caesar's use of the singular in his law suggests that at least he recognized that the old system of colonial boards was insufficient for the needs of the Roman state, and that a new way of doing things needed to be instituted. ${ }^{109}$ The individual Saxa, discussed below, may just represent part of this new approach.

\section{THE SURVEYORS AND THEIR IDENTITY}

The exact identity of the early surveyors who set out the boundary of Cales is more than a little problematic. Cicero in his Pro Balbo, delivered in 56 B.C., mentions Furius and Aulus Cascellius who were praediatores or property experts. ${ }^{110}$ However, these two praediatores, like Marcus Tugio the expert on water rights, seem to have been equestrian jurists who specialized in providing advice on a specific branch of law. ${ }^{111}$ If this is correct, then it does

\footnotetext{
${ }^{106}$ See: Sic. Flac. De Con. Agr. 106.22-108.7. For further discussion, see: Chapter One, ns.79-81.

${ }^{107}$ On the republican land commissions see: Gargola 1995, 58-62; and Braudhead 2007, 150-151.

${ }^{108}$ See by way of example: Hyg. Lim. 136.18-21, 150.3-21.

${ }^{109}$ Caesar's legislation for a sole deductor and mensores in 59 B.C. may be questioned since there is evidence he appointed a board of twenty to recover land, but he certainly used this system when settling his veterans as dictator fifteen years later. For the decemviri of 59 B.C., see: Cic. Ad Att. 2.6; 2.7. For a discussion of Caesar's settlement activity, see: Cic. Ad Fam. 9.17.2; 11.20.3-4; 13.4; 13.5; 13.7; 13.8; Cic. Ad Att. 14.21.2; 15.5.3; 15.26.4; 16.8.1-2; Keppie 1983, 49-58.

${ }^{110}$ On Furius and Cascellius, see: Cic. Balb. 45; Just. Dig. 1.2.1.45; and Sherk 1969, No. 23.

${ }^{111}$ For M. Trugio, see: Cic. Balb. 45. A recent study which considers the specialized nature of water rights in Roman law and the social role of men like Trugio is: Bannon 2009. I regret that I have not had the opportunity to examine this work properly as Bannon seems to make a number of insightful observations on the relationship
} 
not seem likely that Furius and Cascellius would have gone grubbing around the countryside to layout a boundary for the Senate of Cales.

The only other direct clue to the identity of the Roman surveyors in the period before the dictatorship of Caesar comes from a cryptic remark Cicero makes in a passage of his Philippics where he accuses Lucius Antony of being a decempedator.

He (Marcus Antony) also takes precautions for Lucius Antony, who with his colleagues Nucula and Lento was a most equitable surveyor (decempedator) of private and public lands. ${ }^{112}$

Whatever Lucius Antony's faults may have been, the one thing he was not was a surveyor of public lands. There is evidence to show that he was, however, part of a special land commission set up by his brother in 43 B.C. ${ }^{113}$ In this context, Cicero used a term which described a commoner's activity to belittle one of his political opponents. The insult does not provide much information on Lucius Antony as a person, but it does provide insight into the evolution of the terminology used to describe surveyors under the Republic.

Since the Philippics were published after the first book of Varro's work on agriculture where the term mensor was employed in a surveying context for the first time, many scholars might assume that decempedator was simply another contemporary term for a surveyor. The term literally translated means one who works with the decempeda or the ten-foot surveyor's staff, a concept far less ambiguous than mensor. However, Richard Evans in a recent article has noted that much of Cicero's content for the Philippics was drawn from earlier speeches reflecting his glorious conflict with Catilina and Clodius in the $60 \mathrm{~s}$ and $50 \mathrm{~s} .{ }^{114}$

Having examined some of the examples Evans produces to argue his case, I would suggest that his point could be pushed even further. Cicero did not just draw on his past for content and body, he drew on it for language too. If such an argument can be accepted, then it seems likely that the term decempedator belonged to the terminology of the period between Cicero's consulship in 63 B.C. and the start of the Caesarian Civil War, an argument, which

between private water rights and their importance in the settlement of boundary disputes from the time of Sulla to the end of the second century A.D.

${ }^{112}$ Cavebat etiam L. Antonio, qui fuerat aequissimus agri privati et publici decempedator Nucula et Lentone college. (Cic. Phil. 13.37)

${ }^{113}$ On the Antonian land commission of 44-43, see: Cic. Ad Att. 15.19.2; Phil. 5.7; 5.21; 8.26; 12.23; Dio 45.9.

${ }^{114}$ Evans 2008, 62, 81 . 
seems to receive added support by the fact that decempedator does not appear in any other context, suggesting that it was supplanted as the name for a surveyor by mensor. ${ }^{115}$

If this conjecture is allowed, then it suggests that the first professional surveyors did not develop directly out of the Roman army, but came into being indirectly. To appreciate this it is worth considering exactly what social components allowed an individual to become a surveyor. First, an individual needed to have access to education above the elementary level of reading, writing, and basic arithmetic. The geometry used by the surveyors may have been a simple application of the theorem on right triangles, but it was still probably more than the average person learnt about mathematics in the first century B.C. Next, the individual needed to have sufficient free-time to sit in the Roman Forum and pick up the basic rudiments of Roman land law. ${ }^{116}$ Or, by way of alternative, they needed to have access to someone who knew something about it and who was willing to share their knowledge. Third, the person needed sufficient motivation to undertake surveying work and an environment that would tolerate the cultural layering of law over technical skill. Rome was not such an environment, since in that community law was the exclusive province of the nobiles and equites, while technical skill was the proper realm of Greeks or common members of the plebs. The latter were not welcome to involve themselves in legal matters as a general rule. By contrast, Serafina Cuomo's recent investigation of the cultural identity of doctors at Athens suggests that such an attitude was not so pervasive in Greek culture, though even there technical skill generated controversy. ${ }^{117}$ Such a fact might suggest that the first Roman surveyors came into being in Magna Graecia and were themselves Greek. Several pieces of circumstantial evidence support this conjecture, yet that evidence should be viewed with care since it does not answer all questions.

First, there is the evidence of the arbitration of problems at Pompeii and the inscription from Cales mentioned above. Both suggest surveying activity by independent specialists outside the confines of Roman institutions in Campania and Magna Graecia in general. Second, there is the fact that a surveyor's workshop was discovered at Pompeii by archaeologists in 1912. ${ }^{118}$ The workshop contained drafting equipment and one of the few surviving examples

\footnotetext{
${ }^{115}$ See: $T L L 5.127$.

${ }^{116}$ For the conclusions of this study see: Cuomo 2007, 39-42.

${ }^{117}$ For the conclusions of this study see: Cuomo 2007, 39-42.

${ }^{118}$ See: Dilke 1971, 66-73. To the author's knowledge, no comparable workshop has been found anywhere in the world.
} 
of a groma. Such an establishment reflects an Imperial reality shortly before the eruption of Mount Vesuvius. At the same time, it also suggests that surveying had a long tradition in the area. Third, there is the evidence of Athenius Mechanicus. Probably writing in the reign of Augustus, he specifically states at one point in his manual on siege warfare that the mechanicus or machinist should have some knowledge of surveying. ${ }^{119}$ This does not make Athenius or indeed any mechanicus a surveyor. However, it does show that Greeks practiced technical professions and appreciated the need for Roman surveying in the first century B.C. Finally, Andrew Wallace-Hadrill has conclusively shown that there was an extensive system of cultural exchange in Magna Graecia, particularly Campania, that involved local identity, Greek, Etruscan, and Roman cultural elements conducive to the "code switching" necessary for the layering of Roman law, centuriation, and Greek mathematical science that embodied the mensor of the Imperial period. ${ }^{120}$

Set against this body of evidence in favor of Greeks as the predominant group of early surveyors is the fact that with some rare exceptions, Greeks did not serve in the Roman army as anything other than technical advisers to Roman officers. ${ }^{121}$ This makes it difficult to trace their presence in the linguistic changeover from decempedator to mensor, which was surely triggered by the domination of the Roman army from the mid 50s B.C. However, such a factor should not prove a major obstacle since the area of Southern Italy where there was a high concentration of Greeks contained other groups who may have been in an equal position to fill the role of surveyor. One such group was the large number of Sullan veterans settled in Campania. Their presence was initially an agricultural one and that may have prevented them from exercising all the aspects identified above for training as surveyors in this period. The same limitations may not have applied to their children. It seems quite likely that many of those raised by individuals who had served in Sulla's campaigns may well have grown up with an appreciation for the power of technical knowledge. Such an appreciation would have come as a natural byproduct of their fathers' military experiences in the East. And, as the passages from Sallust quoted above show, many of the veterans had the financial resources to provide their children with a first-rate education. The architect Vitruvius, while not a mensor,

\footnotetext{
${ }^{119}$ Ath. Mech. 28. For a text, translation, and commentary, see: Whitehead \& Blyth 2004. The life of Athenaeus and the dates when he wrote are addressed in the introduction to this work at, 15-20

${ }^{120}$ For a discussion of code switching in the context of ancient history, see: Wallace-Hadrill 2008, 7-28. On the cultural dynamics of Campania and the complexities of code switching which would have promoted the development of mensores, particularly around Pompeii, see: Wallace-Hadrill 2008, 92-101, 128-135.

${ }^{121}$ Athenaeus Mechanicus probably provides an example of a Greek who served in this capacity. See: Whitehead and Blyth 2004, 15-18.
} 
may well furnish an example of someone who was able to benefit from this sort of situation. $^{122}$

One last group who should be considered are the children of the municipal aristocracy proscribed by Sulla. Many of these men seem to have returned or grown up in Italy suffering from a considerable disadvantage. While the majority were probably far from destitute, their financial resources were no doubt reduced and they were forever prevented from seeking political office or privilege at Rome. Under such circumstances, some of them may well have used what wealth they had to gain the knowledge and reputation as surveyors if they recognized the unique opportunities that this occupation offered for advancement. To quote Serafina Cuomo:

Techne can compensate for the lack of noble birth by producing honor via alternative routes.... ${ }^{123}$

A surveyor unquestionably possessed the techne or technical skill necessary for the preservation of an ordered world, specifically in terms of land ownership. If the political rivalry of the nobility at Rome was blocking legal redress for local problems involving land disputes, local notables who had nothing to lose by their actions, such as the children of the proscribed, may well have taken matters into their own hands, sorting out the problems of their neighbors and building a political reputation at the same time. The armies of Pompey and Caesar would have provided these men with even more scope once their citizenship was restored, as it was in 59 B.C. To properly appreciate this and to illuminate the ways in which the army, particularly Caesar's army, transformed the identity of the early surveyors from decempedatores to mensores, we must now turn our attention to the life of L. Decidius Saxa.

\section{DECIDIUS SAXA AND SURVEYING IN CAESARIAN ROME}

Cicero in the course of his speeches attacking Antony in 43 B.C. maligned one Saxa as being a brawny, boorish centurian from the wilds of Celtiberia who was only fit to be a camp

\footnotetext{
${ }^{122}$ Vitr. Arch. 1.Pr.2; 6.Pr.4. For discussion and bibliography on the life of Vitruvius, see: Wallace-Hadrill 2008, 144-149.

${ }^{123}$ Cuomo 2007, 40.
} 
surveyor (metator castrorum). ${ }^{124}$ As Saxa is the only person from antiquity who was specifically labeled as a metator, it is worth examining his life in the context of this study. ${ }^{125}$ His family profile is an important consideration because those who could not advance through the normal political channels at Rome may have found it advantageous to take up the role of arbitrator of land disputes as an alternate route; driving the development of the mensor.

Dio Cassius in his history of the Roman Empire, states that Saxa's full name was L. Decidius Saxa. ${ }^{126}$ The Decidii are not well attested in surviving sources. ${ }^{127}$ However, Cicero does mention one $\mathrm{Cn}$. Decidius who was among those ruined by the proscriptions:

It has been said that an injury was done by the family of Cluentius to $\mathrm{Cn}$. Decidius the Samnite, he who was proscribed, during the course of his misfortune. No one treated Decidius more generously than Cluentius. His wealth supported Decidius during his time of misfortune and both he himself and all his friends and relatives acknowledge this. ${ }^{128}$

From this passage, it would seem that the Decidii were a Samnite family who took the side of Marius during the civil war, and were thus proscribed by Sulla. Aulus Cluentius, a wealthy Roman equestrian, then apparently helped Cn. Decidius to get back on his feet. Since many of the proscribed fled to Spain to fight under Sertorius in the years after the proscriptions, Cluentius' assistance could either reflect support for Decidius in such a flight or else support after his return to Italy, or support within Italy during the turbulent period after the proscriptions were over. If Cn. Decidius was Decidius Saxa's father or uncle, then the second of these possibilities would seem most likely. ${ }^{129}$ The argument for $\mathrm{Cn}$. Decidius traveling to

\footnotetext{
${ }^{124}$ See: Cic. Phil. $8.26 ; 10.22 ; 11.12$.

${ }^{125}$ The only serious examination of Saxa's life in English to date is that of Syme, done in 1937. Because Syme did the study, most other scholars have been content to let it stand even though it can be greatly expanded. See: Syme 1937, 132-137.

${ }^{126}$ Dio 47.35.4.

${ }^{127}$ The name Decidius appears in Campania in CIL 10.360, 10.4790, 10.8124; ILS 6038 and a few entries in $A E$, most of them apparently slaves or freedmen. See: $A E 1906.100 ; 1984.633=1994.1168 ; 1990.186$ d; and the unusual statuary base recorded in Alföldy 1984, 91, No. 60.

${ }^{128}$ Cn. Decidio Samniti, ei qui proscriptus est, iniuriam in calamitate eius ab huius familia factam esse dixit. ab nullo ille liberalius quam a Cluentio tractatus est. huius illum opes in rebus eius incommodissimis sublevarunt, atque hoc cum ipse tum omnes eius amici necessariique cognorunt.(Cic. Clu. 161) For a discussion of Cn. Decidius and Cluentius in the context of the proscriptions, see: Hinard 1985, 160-163, 171.

${ }^{129}$ Michael Crawford has recently pointed out that Sertorius created one of several alternate "Romes" in Spain and that many if not most of his Italian followers survived to establish a strong presence in Spain which both Pompey and Caesar capitalized on later. An interesting sideline of speculation, which cannot be taken up here is that Pompey established a policy of clemency for the followers of Sertorius in exchange for the murder of their leader and an end to hostilities. If this idea can be substantiated, then Cn. Decidius may have been a "cliens" to both Pompey and Cluentius. The fact that Saxa later served Caesar suggests that the family may have also forged ties with him too during his time in Spain. For Crawford's remarks, see: Crawford 2008, 636, 642. For
} 
Spain to fight for Sertorius and subsequently being Saxa's father gains support from the fact that Saxa seems to have been born in Spain and that Cn. Decidius and Decidius Saxa were the only prominent members of the family. ${ }^{130}$

Saxa seems to have first served Caesar as a centurion in the Gallic Wars. During operations along the Ebro in 49 B.C. Caesar appointed him as a commander of scouts. ${ }^{131}$ This fact indicates that Saxa had served with Caesar as a centurion for some time, and had a considerable knowledge of the region. ${ }^{132}$ Several years later, in 44, Caesar appointed him tribune of the plebs. ${ }^{133}$ If Syme's interpretations are correct, Antony then appointed Saxa to a special seven-man land commission charged with granting land to veterans. ${ }^{134}$ There is evidence from within Cicero's Philippics that Saxa and a fellow centurion named Cafo did quite well out of this commission, granting themselves lucrative estates in Campania. ${ }^{135}$

Syme is probably right in arguing that he and Cafo marshaled a force of veterans at the outbreak of hostilities in 43 B.C, and marched north to participate in L. Antony's siege of Mutina. ${ }^{136}$ Saxa's services in this enterprise seem to have been so important that he became one of Antony's personal concilium. ${ }^{137}$ As proof of Saxa's importance, he was dispatched to Greece as a legate with a man named Gaius Morbanus to blockade Brutus and Cassius. ${ }^{138} \mathrm{He}$ seems to have discharged his duties with a certain degree of competence and may have commanded some of Antony's legions during the final battle at Philippi, though his name is not recorded in that context. Saxa's general competence and loyalty, however, was most clearly demonstrated by the fact that Antony in 41 B.C. appointed Saxa as governor of

the clemency of Pompey in the Pirate Wars, see: Plut. Pomp. 28; Dio 36.37.3-6; App. Mith. 96, 115; Vell. Pat. 2.32.5-6; and De Souza 1999, 170-173. For the archaeological evidence linking Italy with northern Spain at this time, see: Ruiz de Arbulo 2006, 32-43.

${ }^{130}$ Compare Cic. In Pis. Fr. 4, and 53 with Cic. Phil. 11.12 and consult Syme 1937, 133.

${ }^{131}$ Caes. $B C 1.66$.

${ }^{132}$ For Saxa's service as a centurian, see: Cic. Phil. 8.26. The Hunts Pridianum, a military field report, written on papyrus at the beginning of the second century A.D. shows that scout detachments were normally led by experienced centurions. The monumental inscription of Ti. Claudius Maximus shows that scouts were chosen from the standing ranks of the army on a temporary basses with general long-term military experience and knowledge of the landscape to be investigated as the criteria for selection. On the Hunt's Pridianum, see: P. Brit. Mus. 2851. A discussion of this document can be found in Fink 1971, Doc. No. 63. For the monument of Ti. Claudius Maximus, see: $A E$ 1969/70.583 = $A E 1974.589=A E$ 1985.721; Speidel 1970, 142-153; Campbell 1994, Doc. No. 42 and plate 1; and Austin \& Rankov 1995, 190, plates 7-8.

${ }^{133}$ See: Cic. Phil. 11.12 .

${ }^{134}$ Syme 1937, 134-135.

${ }^{135}$ Cic. Phil. 8.26; 10.22; 11.12; 11.37 .

${ }^{136}$ See: Cic. Phil. 10.22; 11.22; 11.37; 14.10; and Syme 1937, 136.

${ }^{137}$ See: Cic. Phil. 13.2. On the concilium in general, see: Francese 2007, 110-112.

${ }^{138}$ App. BC 4.87; Dio 47.35.2; 47.35.4; 47.36.2-3. 
Syria. ${ }^{139}$ Here Saxa and his younger brother faced Parthian forces lead by the Roman renegade Labienus and Crown Prince Pacorus. Labienus captured the brothers Saxa and executed them, putting an abrupt and violent end to an unusual and impressive saga of social advancement. $^{140}$

While Saxa's career was unusual, it was by no means unique for the times. A decade after Saxa's death, Lucius Tarius Rufus who was a minor land-holder from Pisinum rose through the ranks of the army to become a legate of Augustus and eventually consul at Rome. The major difference between Rufus and Saxa seems to have been in the nature of their advancement. Rufus rose on sheer military ability and was a personal legate to Augustus during the civil war before holding any important political office. Saxa, by contrast, does not seem to have held any significant military commands prior to becoming tribune of the plebs in 44. Saxa's advancement seems to have been due to rather different circumstances. Two clues to those circumstances lie in his cognomen and in the fact that Cicero twice refers to him as metator. ${ }^{141}$

As has been well established, the cognomen in the late Republic was a sign of equestrian or senatorial status. In addition, each cognomen usually had some specific attributive quality associated with the person who bore it. ${ }^{142}$ In this respect, Saxa seems to be utterly unique as a cognomen in the Republican period. As C. A. Francese has pointed out, the word tends to be associated with architecture and means "a building stone". ${ }^{143}$ The use of such a word as saxa as a name at a time when cognomina carried significance suggests a connection with construction.

The implications of this cognomen as a construction term and its links to surveying become apparent when it is considered against two passages of Cicero's Philippics:

There is also some fellow Saxa, whom Caesar has hoisted on us as a tribune of the plebs, although he comes from the furthest reaches of Celtiberia. He was previously a camp measurer (castrorum antea metator), but now, so he hopes, a

\footnotetext{
${ }^{139}$ Dio 48.24.2-8.

${ }^{140}$ Dio 48.25.2-4.

${ }^{141}$ See: Cic. Phil. $11.12 \& 14.10$.

142 See: Salway 1994, 124-128; and Uría 2006, 13-21.

${ }^{143}$ Francese 2007, 145.
} 
city measurer. Since he has no links with our city, may this be an ill-omen on his head, without harm to us. ${ }^{144}$

Truly, if he (Antony) is without doubt an enemy of the colonies and municipalities, what do you consider him to be in respect of this city, with which he desired to satiate the poverty of his band of brigands, and which the skilful and crafty measurer (metator) Saxa has already divided up with his ten-foot surveyor's $\operatorname{rod} ?^{145}$

Syme read the first of these two passages and interpreted castrorum antea metator as referring to Saxa as a member of the land commission of 44 and as evidence that Saxa was a praefectus castrorum. ${ }^{146}$ However, a close examination of the literary context suggests a slightly different meaning. Syme recognized that Celtiberia was a close slur on Saxa's Spanish provenance, but he failed to recognize that the sentence contained three such pieces of invective. The first was set up by ex Celtiberia, invalidating Saxa's right to be tribune. The second uses castrorum metator to invalidate Saxa's right to "measure" or survey the "Urbs" or Rome. The third is an inversion of the principle, which uses Saxa's identity as a foreigner to validate him as being worthy of a curse when in point of fact Saxa was without doubt of Italian stock.

Given the close correlation between the ideas of the first and third exemplum, it seems very unlikely that the idea of the castrorum metator should be equated to a praefectus castrorum. It seems far more likely that the holder of such an office would have been socially qualified to mark out Rome in the eyes of men like Cicero. As an additional point, the office of the praefectus castrorum was almost certainly one of the few military innovations that should be attributed to Augustus. ${ }^{147}$

The use of metator may have been an indirect reference to Saxa as a member of the Antonian land commission. However, if it was, then it is rather odd since when Cicero wanted to insult another member of that body, he used the term decempedator. ${ }^{148}$ Saxa, as has already been

\footnotetext{
${ }^{144}$ Accedit Saxa nescio quis, quem nobis Caesar ex ultima Celtiberia tribunum pl. dedit, castrorum antea metator, nunc, ut sperat, urbis; a quo cum sit alienus, suo capiti salvis nobis ominetur. (Cic. Phil. 11.12).

${ }^{145} \mathrm{Si}$ vero coloniarum et municipiorum sine ulla dubitatione hostis est, quid tandem huius censetis urbis, quam ille ad explendas egestates latrocinii sui concupivit, quam iam peritus metator et callidus decempeda sua Saxa diviserat? (Cic. Phil. 14.10).

146 Syme 1937, 134-136.

${ }^{147}$ See: Saddington 1996, 244-248.

${ }^{148}$ Cic. Phil. 13.37.
} 
noted was the only person in the whole of classical antiquity to be singled out for identification with the term metator. Therefore, the word must have had some specific connotations for him. Otherwise, Cicero would have contented himself with calling Saxa a decempedator or land surveyor.

As has been discussed elsewhere, the term metator was used to describe an enlisted man who marked out the castra in the period after Caesar's dictatorship. And whatever Saxa may have been, he was clearly more than a mere enlisted camp technician. The logical explanation as to why Cicero used metator to describe Saxa and decempedator to describe L. Antony would seem to be that Saxa was himself a practicing decempedator or as Varro called such people, a mensor. This explanation fits the literary pattern outlined above. The reference to Celtiberia was a slur on a Spanish birthplace, and the reference to metator denigrated Saxa's profession. It also allows us to postulate a course of advancement reflecting the role of technical specialists in Caesar's army that led directly to the rise of the mensores.

Caesar's army, where Saxa seems to have started his rise to prominence, was without doubt a technically savvy engine of war. Two passages of Caesar's Gallic Wars amply demonstrate the fact. They also show that while Caesar appreciated technical skill and was proud of his army's abilities, he himself was no practicing technician. On the other hand, if Saxa was a mensor as I have argued, then he may have been involved in some of Caesar's engineering projects, since the text of Balbus cited in Chapter Two has shown that some mensores were involved in such activities.

The first of the two passages, which should be considered that reflects this high degree of engineering skill is Caesar's description of his bridging of the Rhine in 56 B.C.:

He established this plan for a bridge. He joined a pair of piles each a foot and a half thick and slightly sharpened at one end, equal in length to the depth of the river, with a gap of two feet between each. Once these piles were lowered into the river, he sank them with cranes and drove them home with pile drivers so that they were not perpendicularly straight like stakes, but so that they were prone and formed an angle, leaning in the direction of the river's flow. Opposite to these piles, he established two more piles fastened in the same manner forty feet down stream, so that they were turned to slope against the force and flow of the river. Each of these pairs of piles were, moreover, held apart by beams two feet thick, which was the space joined between the piles, and so each of the pairs was separated from its opposite number by connecting timbers; in this way, each side 
was joined to and separated from its opposite, and the strength of the work and the nature of the materials was such that this structure was bound tightly together by the greater force of the water. ${ }^{149}$

Caesar constructed this bridge in just ten days to over-awe the Germans on the far side of the Rhine. He included a lengthy description of the bridge, which was not the only one he built, in his commentaries to over-awe the public at Rome with the technical abilities of his legions. ${ }^{150}$ It is also likely, that the impressive imagery of the bridge distracted the attention of his readers away from the fact that Caesar's German expedition was not all that successful or impressive in and of itself. ${ }^{151}$

Regardless of why it was included, it is clear from the Latin text, that while Caesar appreciated the technical aspects of the bridge's construction, he himself did not design it, even if he takes full credit for it as the commander in chief. Some scholars have attributed the bridge's design to Mamurra, Caesar's praefectus fabrum. ${ }^{152}$ However, this is questionable since the praefectus fabrum was mainly an administrative post that did not require any practical knowledge of engineering and which from the mid first century B.C. down to the time of Hadrian was normally given to rising young equites. ${ }^{153}$ Mamurra was just such an eques. ${ }^{154}$ As a consequence, it is unlikely, though by no means impossible, that Mamurra designed the bridge for Caesar. What is far more likely is that Mamurra oversaw its design and construction by other men whose training was more specialized. Decidius Saxa, as is shown below, may have been one such individual.

The second set of passages from Caesar's Gallic Wars which resonates with Saxa's name and apparent surveying skill are those describing the siege works outside Avaricum in 52 B.C.:

\footnotetext{
${ }^{149}$ Rationem pontis hanc instituit. Tigna bina sesquipedalia. paulum ab imo praeacuta dimensa ad altitudinem fluminis intervallo pedum duorum inter se iungebat. Haec cum machinationibus immissa in flumen defixerat fistucisque adegerat, non sublicae modo derecte ad perpendiculum, sed prone ac fastigate, ut secundum naturam fluminis procumberent, iis item contraria duo ad eundem modum iuncta intervallo pedum quadragenum ab inferiore parte contra vim atque impetu fluminis conversa statuebat. Haec utraque insuper bipedalibus trabibus immissis, quantum eorum tignorum iunctura distabat, binis utrimque fibulis ab extrema parte distinebantur; quibus disclusis atque in contrariam partem revinctis, tanta erat operis firmitudo atque ea rerum natura ut, quo maior vis aquae se incitavisset, hoc artius inligata tenerentur. (Caes. BG 4.17.3-7)

${ }^{150}$ Caes. $B G$ 4.18.1.

${ }^{151}$ I owe this observation to conversations with my assistant Tania Hayes.

152 Green 2005, 296.

${ }^{153}$ For references on this point, see: this chapter, n.52.

${ }^{154}$ On Mamurra, see: Plin. NH 36.7; Hor. Sat. 1.5; Cat. 29,41, 43, 54, 57, 93; Cic. Ad Att. 7.7; 13.52; Suet. Iul. 74.
} 
...He (Caesar) ordered that a ditch be dug twenty feet deep with perpendicular sides, so that the bottom of this trench be as wide as the edges at the top of the trench were far apart. He took all the other fortifications back four hundred feet from this ditch... This area having been left open, he drew up two more trenches fifteen feet wide and the same in depth. The innermost of these, which was in level and low-lying ground, he filled with water diverted from the river. Behind these trenches, he raised a rampart and wall twelve feet high. To this he added a parapet and battlements with extremely large forked stakes protruding at the gaps of the parapet and breastwork, .... and he surrounded the entire work with towers, which were eighty feet apart. ... Therefore, when the trunks of trees or very sturdy branches were cut, and the bark stripped from them and their ends sharpened, he dug a continuous trench five feet deep. Here those stakes were lowered down and anchored in place at the bottom, protruding from amongst the branches in such a way that it was not possible for them to be pulled up. There were five separate rows joined and intertwined with one another; on account of which, anyone who entered the trench would impale themselves on sharpened stakes. They call these cippi. In front of the cippi which were arranged in an oblique rose like the five on a die were pits three feet deep, dug so that they narrowed little by little down to the bottom. Tapering stakes the thickness of a man's thigh sharpened at one end and hardened in the fire were sunk so that they did not protrude more than four finger's length from the ground; at the same time, for the purpose of securing and providing stability to the stakes, earth was trampled down at the bottom to the height of one foot. The rest of the pit, to hide the trap, was covered with twigs and brush. Eight rows of this sort were laid out with the distance of three feet between each. They call these lilies from their similarity to the flower... ${ }^{155}$

Complex siege works such as the ones described here would have required careful surveying to be effective. Caesar claimed in his Gallic Wars that the encirclement stretched for more than fourteen miles, and must have been a massive undertaking. ${ }^{156}$

Because of the philological nature of his cognomen in relation to building stones, his apparent duties as a surveyor, and the scarcity of this cognomen in the period before 60 B.C.,

\footnotetext{
1557.72 ...Fossam pedum viginti directis lateribus duxit, ut eius fossae solum tantundem pateret quantum summae fossae labra distarent. Reliquas omnes munitiones ab ea fossa pedes quadringentos reduxit... Hoc intermisso spatio duas fossas quindecim pedes latas, eadem altitudine perduxit, quarum interiorem campestribus ac demissis locis aqua ex flumine derivata complevit. Post eas aggerem ac vallum duodecim pedum exstruxit. Huic loricam pinnasque adiecit grandibus cervis eminentibus ad commissuras pluteorum atque aggeris... et turres toto opere circumdedit, quae pedes LXXX inter se distarent. 7.73 ... Itaque truncis arborum aut admodum firmis ramis abscisis atque horum delibratis ac praeacutis cacuminibus perpetuae fossae quinos pedes altae ducebantur. Huc illi stipites demissi et ab infimo revincti, ne revelli possent, ab ramis eminebant. Quini erant ordines coniuncti inter se atque implicati; quo qui intraverant, se ipsi acutissimis vallis induebant. Hos cippos appellabant. Ante quos obliquis ordinibus in quincuncem dispositis scrobes tres in altitudinem pedes fodiebantur paulatim angustiore ad infimum fastigio. Huc teretes stipites feminis crassitudine ab summo praeacuti et praeusti demittebantur, ita ut non amplius digitis quattuor ex terra eminerent; simul confirmandi et stabiliendi causa singuli ab infimo solo pedes terra exculcabantur, reliqua pars scrobis ad occultandas insidias viminibus ac virgultis integebatur. Huius generis octoni ordines ducti ternos inter se pedes distabant. Id ex similitudine floris lilium appellabant... (Caes. BG 7.72-73, excerpted to a great degree).

${ }^{156}$ Caes. $B G$ 7.74.2.
} 
it seems quite likely that L. Decidius gained the appellation of Saxa by designing and / or building impressive engineering accomplishments for Caesar. Such accomplishments at any rate would have been adequate enough reason for Caesar to elevate Saxa first to equestrian status and then to the Senate via the tribunate of 44. Cicero's account in his Philippics provides further evidence for Saxa's activities as a surveyor and engineer. There is of course Cicero's reference to Saxa as someone who was involved in the surveying or distribution of land to veterans. However, one did not have to be a surveyor to serve on a land commission. None of the others mentioned in connection with the commission of 44 had any surveying experience whatsoever. Far more important are Cicero's observations that Saxa: ...castrorum antea metator, nunc, ut sperat, urbis... and ...quam iam peritus metator et callidus decempeda sua Saxa diviserat.... ${ }^{157}$ These remarks suggest that either Caesar or Antony appointed Saxa as what might best be termed mensor aedificius urbis Romae, a surveyor of public works for the city of Rome. ${ }^{158}$ If such a conjecture is correct, then it is likely that Saxa was involved with and perhaps responsible for starting the massive redistricting program Caesar supposedly undertook and which Augustus finished. ${ }^{159}$

In connection with the redistricting project, it also seems likely that Saxa was in some way responsible for the surveying work connected to Caesar's massive building program. Since Caesar is rarely considered as a monumental builder at Rome, there is little available scholarship on the role his projects may have played in his political agenda. ${ }^{160}$ But as D. C. Feeney has proven, Caesar restructured the temporal reality of Rome when he reformed the calendar, and it seems likely that he may have restructured the spatial reality too. ${ }^{161}$ It is possible that Caesar's temporal and topographical changes to the identity of Rome were intended more as a means of addressing short-term problems requiring immediate attention rather than as the statement of absolute power many doubtless perceived them to be. However, scholars such as Katherine Welch have pointed out that the erection and dedication of structures like his temple to Felicitas and Caesar's Forum seem to have been carefully worked into his political agenda in a way that avoided calling attention to his dictatorial

\footnotetext{
${ }^{157}$ See: $n .144 \& 145$ of this chapter for text and translation.

${ }^{158}$ For examples of this sort of mensor see: Col. RR 5.1; CIL 6.1975; and Chapter Two, n.43 \& 49.

${ }^{159}$ Suet. Iul. 41.3; Wallace-Hadrill 2008, 291-295 \& 298-313.

${ }^{160}$ This is perhaps due to the fact that Caesar's building program tends to be examined collectively with that of Augustus and so few scholars bother to consider Caesar's separately. As Barbra Levick has pointed out it is often hard to separate Caesar from Augustus and objectively assess Caesar's agenda and its impact on Augustan Rome. See: Levick 2009, 212-214.

${ }^{161}$ See: Chapter One, n.13 \& 14 for references. Also see: Fantham 2009, 153-155.
} 
presence. ${ }^{162}$ In either case, it is clear from a passage of Cicero's Academica that Roman and to a lesser degree Italian aristocrats placed a great deal of emphasis on the temporal and topographical features associated with the city of Rome, considering knowledge of these features to be as critical as a knowledge of Latin in the establishment of Roman identity. Mensores who altered these features of the city in the service of Caesar, whilst not popular, would have nevertheless been relatively important, further solidifying their role. Cicero, addressing Varro in his Academica and discussing that author's works on antiquarian learning, makes it quite clear that not all Romans were conversant with the details of their culture. They needed to have them explained and placed in a temporal and topographical context. $^{163}$

That context was encapsulated within the city of Rome and its history. ${ }^{164}$ Because of this, those who could not or more probably would not learn and show proper deference to Rome's traditional topography and history could not be truly Roman even if they spoke impeccable Latin. Being Roman for Cicero and Varro meant being immersed in the language, traditions and urban features of Rome. Any radical changes to these features meant a transformation in being Roman. Thus, while the circumstances of Caesar's dictatorship forced Cicero to acquiesce to the Caesarian changes such as the Julian Calendar and the Forum Iulium, those changes must have been as alarming to Cicero as the concept of losing land to the Caesarian land surveyors:

They are indeed surveying the land at Veii and Capena; this is not far from my Tusculan estate. However, I am not at all frightened. I will enjoy this as long as possible and hope that this will be forever. If this does not turn out so, then, since as befits a brave hero and also a philosopher I have decided that staying alive is the finest of things, I cannot help but thank the fellow by whose kindness I have gained that result. ${ }^{165}$

\footnotetext{
${ }^{162}$ See: Welch 2008, 183, 186-187, \& 199. R. B. Ulrich in a deeply flawed article published in 1993 argued that Caesar created his forum to deliberately transform the political landscape of Rome and impose his will as dictator on the city. In spite of the article's flaws, Ulrich may have a point. See: Ulrich 1993, 49-80. For a more balanced account of the Forum Iulium as a monument, see: Morselli 1993, 299-316.

${ }^{163}$ Cic. Ac. 9. For discussion of this passage, see: Wallace-Hadrill 2008, 232-235 \& 259-260.

${ }^{164}$ This concept has most recently and most fully been explored by Wallace-Hadrill in two lengthy chapters covering pages 215 to 313 of his 2008 publication. Anyone who truly wishes to understand the complex interplay between language, culture, and place within Roman thinking in the late Republic must consult this study.

${ }^{165}$ Veientem quidem agrum et Capenatem metiuntur; hoc non longe abest a Tusculano; nihil tamen timeo. Fruor dum licet, opt out simper liceat; si id minus contigerit, tamen quoniam ego vir fortis idemque philosophus vivere pulcherrimum duxi, non possum eum non diligere, cuius beneficio id consecutus sum. (Cic. Ad Fam 9.17.2)
} 
In spite of the words, Cicero's tone in this letter clearly conveys his concern at the prospect of having his estates surveyed, as well as his resentment towards Caesar. If Cicero resented Caesar for sparing his life and altering what it meant to be Roman, then it is no wonder that he chose to turn his invective against men such as Saxa who were not only outsiders but technicians that carried out Caesar's innovations and even benefitted from them.

From this point, it might be argued that Cicero's invective against Saxa was just that, invective intended to abuse a provincial who had done well out of the Caesarian reforms. Yet, it must be remembered that for any invective to have affect it must have some basis in reality. For Cicero's jibe about being a castrorum antea metator to have hit its mark, there must have been a substantive target at which Cicero could aim his remark. The best target Cicero could have hoped to have for his jibe was the reality of Saxa as an upstart provincial of little consequence who climbed his way to success through sheer talent.

In this context, it is worth remembering the person of the mensor Balbus. Like Saxa, Balbus seems to have been a man of little consequence who was a surveyor for the Roman army. Like Saxa, his work seems to have involved siege-works and the construction of bridges. ${ }^{166}$ Like Saxa, he seems to have reaped a considerable reward for his services during the Dacian wars, though it did not amount to something as grand as the post of tribune of the plebs. ${ }^{167}$ And if a mensor could carry out such duties and reap rewards in the age of Trajan, then it seems quite probable that something similar would have been possible in the age of Augustus and Caesar.

By accepting Saxa's identity as an early decempedator or mensor, it is possible to establish that Caesar did indeed have access to young men of talent who were capable of carrying out complex surveying operations. Moreover, the presence of Vitruvius in the ranks of Caesar's army shows that Saxa was not the only technician in Caesar's legions, though Saxa was doubtless as exceptional a representative of the mensores as Balbus seems to have been under Trajan. $^{168}$

\footnotetext{
${ }^{166}$ For the text of Balbus demonstrating this point, see: Chapter Two, n.103 \&106.

167 See: Chapter Two, n.106.

${ }^{168}$ See: Vitr. Arch. 1.pr.2; and Balb. Ad Cels. 204.1-16 \& 204.23-32.
} 
These technically trained soldiers were, then, the men to whom Caesar turned to when it came time for him to distribute land to his veterans and reorganize the city of Rome to better suit the existing political order. They doubtless joined Caesar in Gaul for the same reasons that so many young men from the equestrian order did: they sought the opportunities of advancement denied to them at Rome, but which were available in the "alternative states" controlled by Proconsuls like Caesar and Pompey. ${ }^{169}$ Some may have served mainly as centurions as Saxa did. Others may have worked their way up from common enlisted men who acted as mensores in the traditional Republican sense of the term found in Lucilius at the start of this investigation. ${ }^{170}$ Those who survived the wars probably ended up far better off than they had started out.

Whatever their duties and career path may have been, they surely recognized their importance and influence once Caesar assigned them to divide up land for their fellow soldiers. This sense of importance and the general dominance of Caesar's army in the years after 47 B.C. probably caused the term mensor to supplant decempedator as the common word for a surveyor. Likewise, it seems quite probable that the desire of the new surveyors to distinguish themselves from the men who marked out the castra caused a destinction between mensor and metator to take place. The five years between Caesar's first land grants in 47 B.C. and Cicero's Philippics in 43 would have been ample time for such a usage to creep into the popular vocabulary. Some may doubt that a conservative like Cicero would make use of this sort of recent linguistic development. And in general I would agree with this. However, in a special case such as Decidius Saxa, I have no difficulty in accepting that Cicero adopted a new connotation of a word better to make his point.

Now we have nearly completed the circle of the study and the evolution of the mensor. For in the surveyors of Caesar the mensores of the Republican army met the decempedatores and became something like the mensores of the Imperial period examined earlier. The transformation however was not quite complete when Caesar was assassinated on the Ides of March. His mensores were probably not fully expert in the law. The mastery of the legal aspects of surveying was probably a refinement made by Augustus. ${ }^{171}$ Likewise, the training

\footnotetext{
${ }^{169}$ See: Crawford 2008, 636-642 for a discussion of this concept.

${ }^{170}$ See: Lucil. Fr.100 and n. 1 of this chapter.

${ }^{171}$ It is an open question as to how far any mensor was ever a master of land law. Most may have only known this subject in a desultory sort of way, a concept suggested by the fact that the main topics treated by the text in the Corpus Agrimensorum were mainly legal. Whether this preference for legal topics reflects limitations
} 
of slaves and freedman as mensores was probably a part of the first emperor's employment of the Roman Land Surveyors to reshape the world in his image. However, that reshaping and the mensores' role in it is another far more complex issue requiring an investigation longer than any undertaken here.

amongst the mensores or is a literary topos intended to lend respectability to their profession in the eyes of the Roman imperial aristocracy is a complex question that has been discussed to a great degree by most scholars examining the mensores. However, I would argue that a final answer to this question should depend on a close study of the Corpus Agrimensorum for a full understanding of just how Augustus incorporated them in the imperial world order. The same is true regarding the role of imperial slaves and freedman in the duties of surveying. Such studies are well outside the scope of this work. See: Dilke 1971; Campbell 1996; and Campbell 2000. 


\section{CONCLUSION}

Roman surveying was a changing and dynamic social institution that evolved from the time of the Gracchi through to the second century A.D. Both surveying and surveyors evolved in response to Roman political needs and social pressure. As was shown at the end of Chapter One, the Romans in the second century B.C. used the system of centuriation to delineate land used as part of a colonia. The colonia was used as an instrument of political and military control. A board of three, the triumviri, carried out its establishment. Under the triumviri were the finitores, a group of young men chosen from the ranks of the equites or equestrians. They were probably responsible for overseeing surveying operations, establishing boundary markers in accordance with ancestral ritual, and perhaps for orienting the survey of colonial land. It is possible that the mensores of the second century carried out the backbreaking work of actually measuring out the limites of the colonia. However, there is no hard evidence to prove such involvement on the part of the Republican mensores. As the evidence examined at the start of Chapter Three indicates, the best that can be said for the mensores of the second century B.C. is that they were veteran soldiers chosen from the rank and file for the purpose of laying out the castra or marching camp. The system used for this task, known as castramentation, was related to centuriation and was conducted using a social hierarchy similar to that used to establish a colonia. A senatorial tribune oversaw a group of centurions and enlisted mensores in what was probably an increasingly organized and sophisticated operation.

As discussed in Chapter Three, this system with modifications seems to have functioned admirably down to the time of Sulla. However, the devastating aftermath of the Social War and Sulla's own political program created extensive social dislocation that led to complex and often violent conflicts over land ownership. To address these disputes many individuals and communities at first turned to the Roman court system and the assistance or intervention of Roman politicians such as P. Cornelius Sulla and L. Sergius Catilina to solve their problems. But when politics at Rome frustrated such attempts, the citizens of the municipia turned to less orthodox methods of redress. In some cases it was outright rebellion. In others the different factions worked with Roman officials to find local men who were willing to act as arbitrators and surveyors. These individuals were probably called decempedatores in the early days. They probably first came into being in the decade just preceding Caesar's 
consulship in 59 B.C. and came from the ranks of Greeks in southern Italy, the children of Sulla's veterans, or the children of the proscribed. The latter seem to have been particularly ripe for such a course of action as they could not advance through the normal political channels at Rome and thus had nothing to lose by establishing a reputation through unorthodox means. It is likely that many of these men to advance themselves even further took the opportunity of joining men like Caesar in the provinces where their surveying talents were doubtless a benefit to the Roman Army. L. Decidius Saxa probably provides an excellent if exceptional example of this.

When Caesar established full control over Rome, he employed the technicians from his army to divide up land for his veterans and to help him reorganize the public spaces in the city. Cicero's fear of Caesar's mensores underlines the impact that these surveying operations made on the local population, and the important status that the mensores enjoyed. This significant status probably caused a change in terminology with decempedator giving way to mensor as the term for a surveyor. At the same time as Caesar's mensores gained prominence as surveyors, it is likely that they sought to solidify their status by distinguishing themselves from the enlisted men who were still only involved in marking out the castra. Thus the term metator took on the disreputable connotations found in Cicero. Metator seems to have lost much of that negative tone in the imperial period, though the term continued to refer to a camp technician who was of inferior status.

The distinction between mensor and metator was only the first distinction in specialization that took place in the ranks of the Roman surveyors. As was seen in Chapter Two, the mensores themselves became increasingly specialized as they took on more and more complex tasks, and as they refined their skill and legal possession within Roman society. By the beginning of the second century A.D., surveyors were broken down into two broad categories with the mensor gromaticus or agrimensor dealing with horizontal surveying, and the mensor librator attending to the far more complicated and demanding problems of surveying in both the vertical and horizontal.

Because of these technical skills, many mensores, particularly those in the Roman army became quite prominent and influential, occupying a unique social possession as a conduit to power. They channeled specialist knowledge upward to the emperor in a way that enabled him and his deputies to conduct complicated military operations, demarcate lines of authority, 
and maintain order. At the same time, they channeled it downward to the common people, providing the exact knowledge necessary to solve problems involving land ownership and municipal services.

While noting this unique position and remarking upon other aspects of the mensores' changing role under the Empire, this thesis has made no effort to trace the events that drove the mensores development in the years after Caesar's assassination. Likewise it has made no effort to definitively trace their incorporation in the imperial army in the century following the death of Augustus. However, it provides an admirable springboard for such an investigation and for an investigation into the role of the mensores in the reshaping of the Roman world undertaken by Augustus. 


\section{FIGURES}
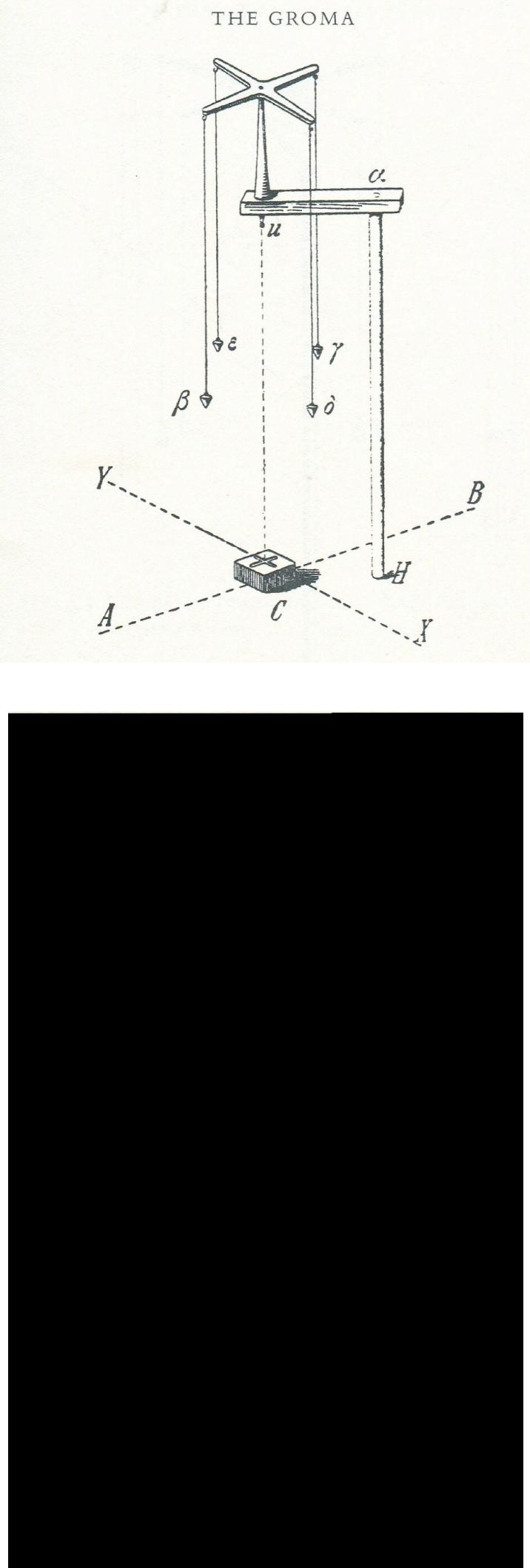

Figure 1: Reproduced from Schulten's reconstruction of a Groma as presented in Lewis 2001, 127, FIG. 5.1
Figure 2: Reproduced from the reconstruction of Groma by Della Corte as presented in Lewis 2001, 128 FIG. 1 


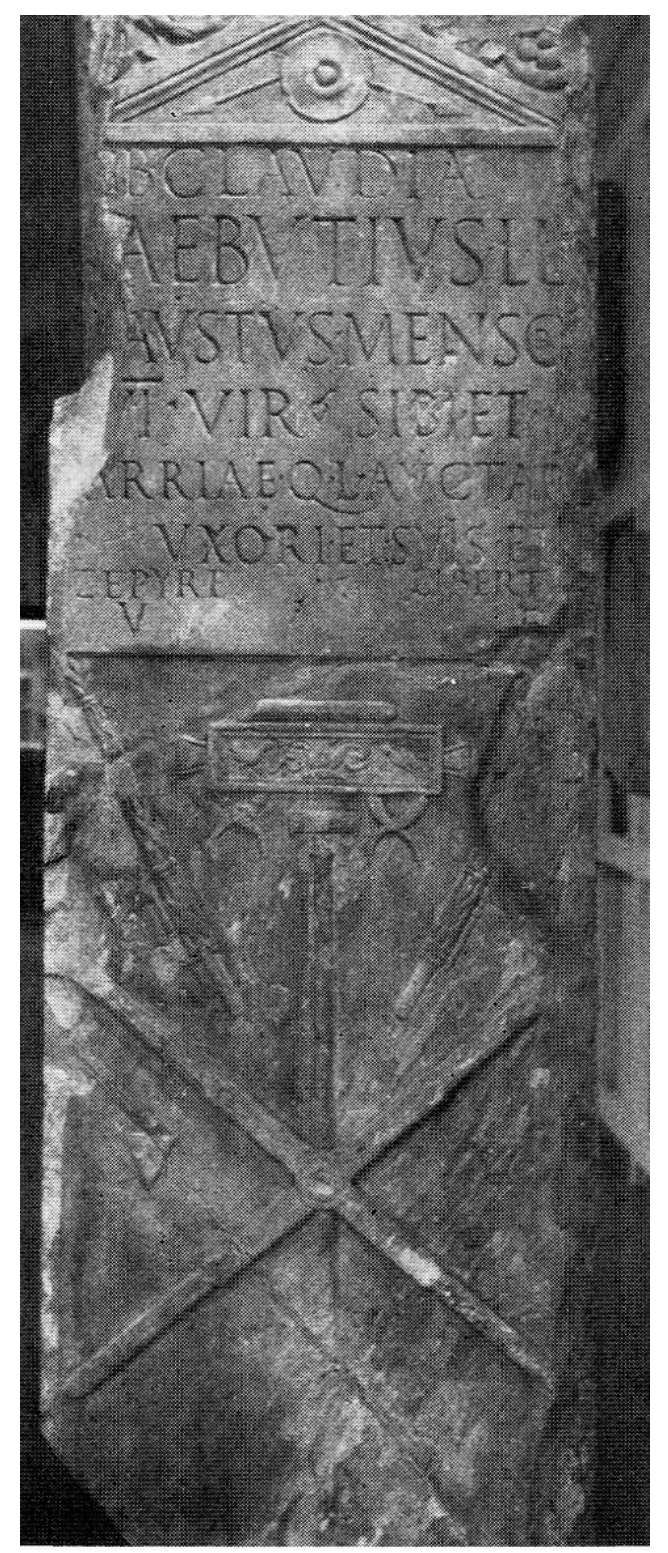

Figure 3: Reproduced from Zimmer 1982, 197, FIG. 141

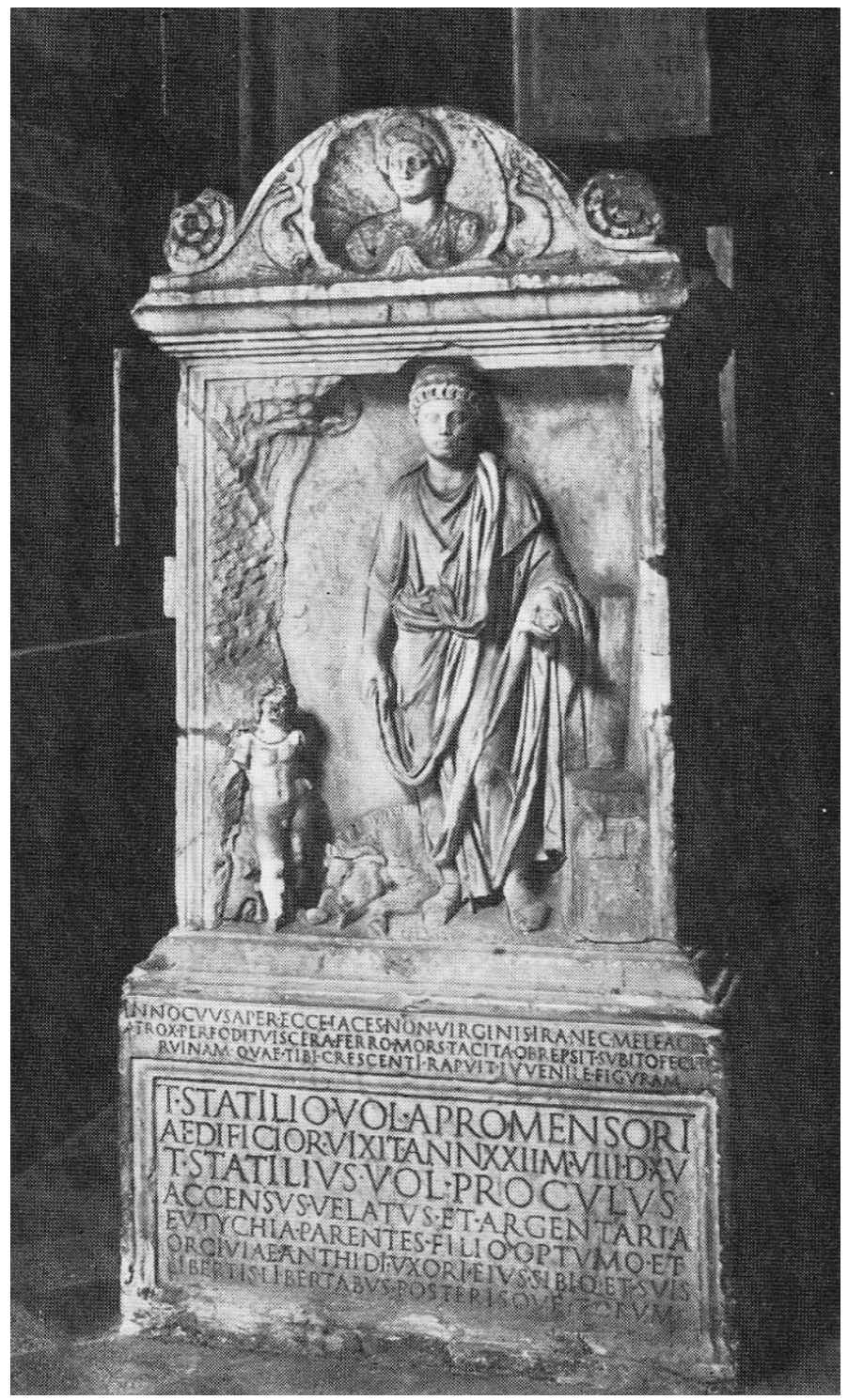

Figure 4: Reproduced from Zimmer 1982, 197, FIG. 142. 


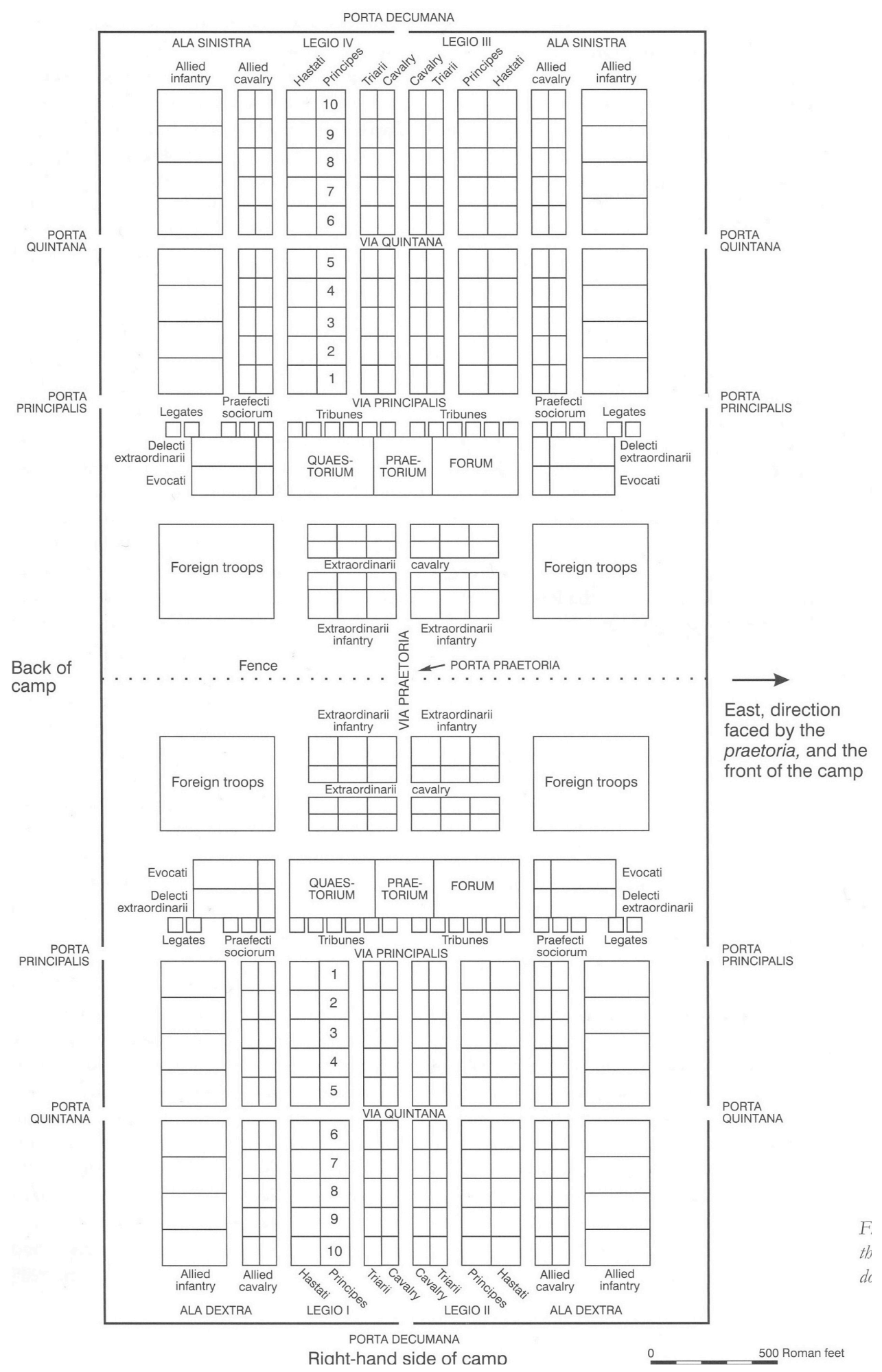

Figure 5: Plan of Polybian Camp reproduced from Dobson 2008, 69, FIG. 23 


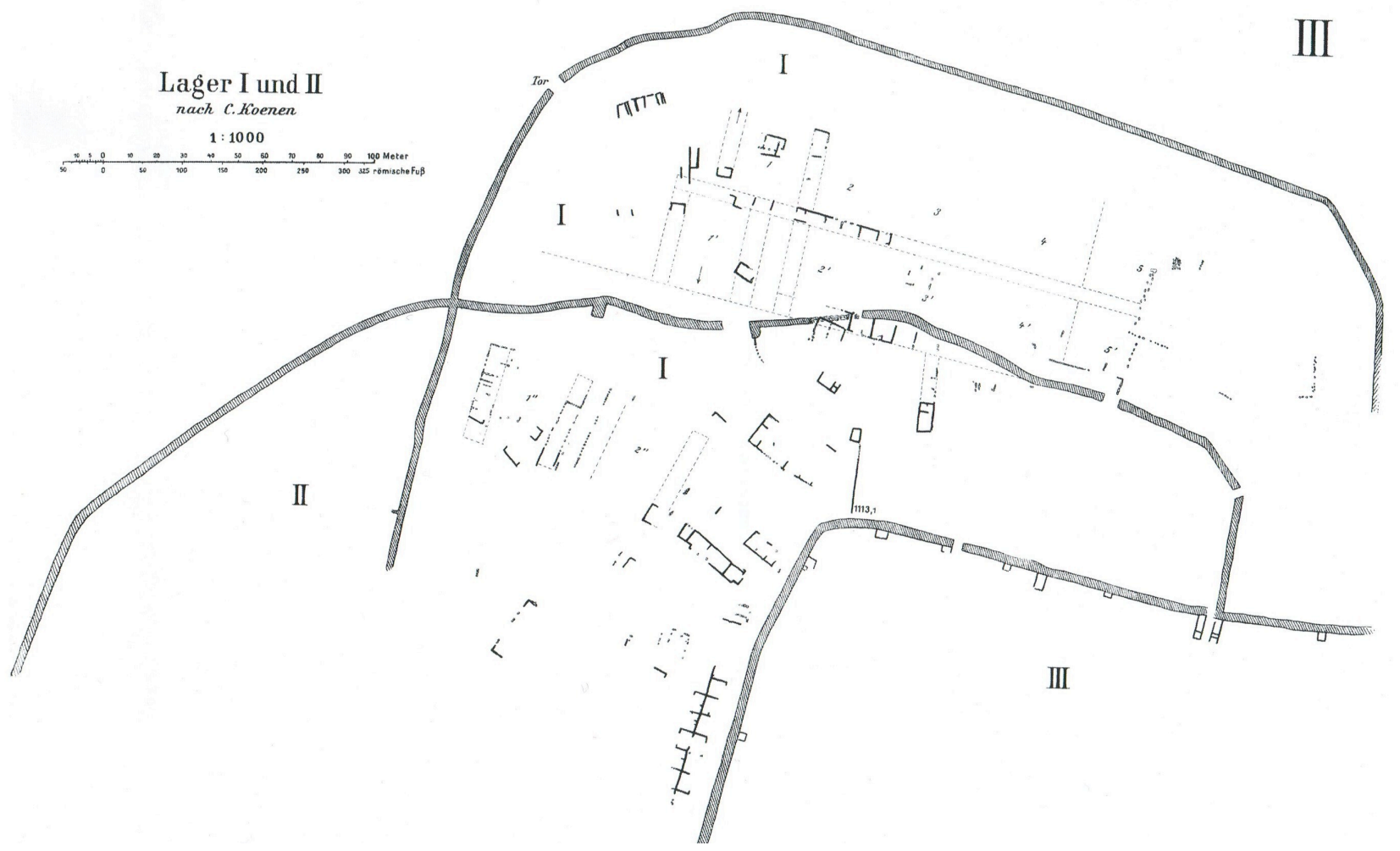

Figure 6: Plan of Lager 1 and 2 reduced from Schulten 1929, reproduced from Dobson 2008, 128, FIG. 42 


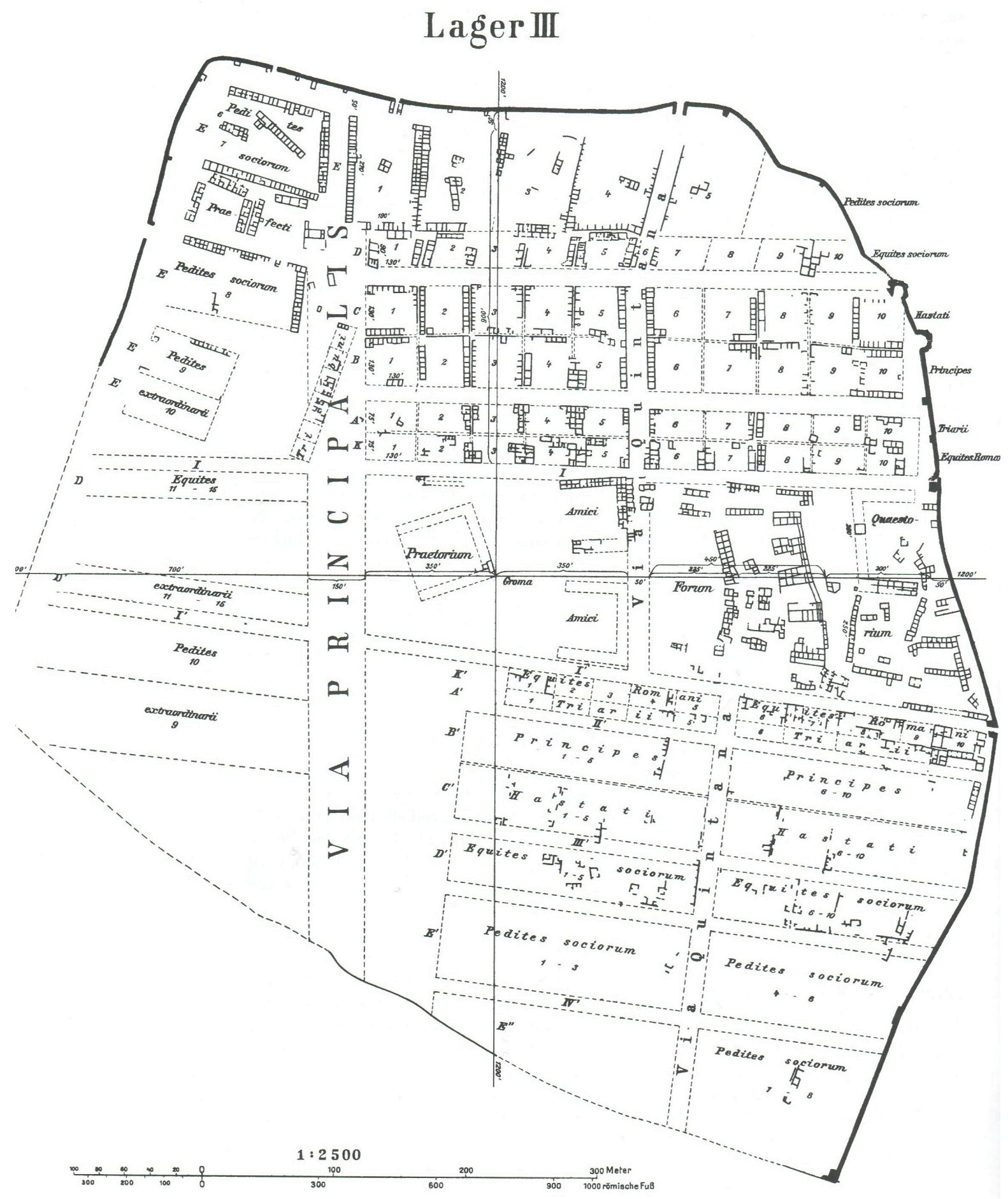

Figure 7: Plan of Lager 3, reconstructed by Schulten, reproduced from Dobson 2008, 140, FIG. 53. 


\section{BIBLIOGRAPHY}

Abad, Casal, L., S. Keay, \& Ramallo Asensio. (eds.) "Early Roman Towns in Hispania Tarraconensis." Journal of Roman Archaeology. Supplementary Series, No. 62. Portsmouth, RI, 2006.

Alföldy, G. Römische Statuen in Venetia et Histria: Epigraphische Quellen. Heidelberg. Winter, 1984.

Austin, N. J. E. \& N. B. Rankov. Exploratio: Military and Political Intelligence in the Roman World from the Second Punic War to the Battle of Adrianople. London, New York: Routledge, 1995.

Bannon, S. J. Gardens and Neighbors: Private Water Rights in Roman Italy. Ann Arbor: University of Michigan Press, 2009.

Benelli, E. "The Romanization of Italy through the Epigraphic Record." In: Italy and the West: Comparative Issues in Romanization. Keay and Terrenato (eds.). Oxford: Oxbow Books, 2001, 7-16.

Berggren, J. L. \& A. Jones. Ptolemy's Geography: An Annotated Translation of the Theoretical Chapters. Princeton: Princeton University Press, 2000.

Bispham, E. "Coloniam Deducere: How Roman was Roman Colonization during the Middle Republic?" In: Greek and Roman Colonization : Origins, Ideologies and Interactions. Bradley \& Wilson (eds.). Swansea: Classical Press of Wales, 2006, 73-160.

Bispham, E. From Ausculum to Actium: the Municipalization of Italy from the Social War to Augustus. Oxford, New York: Oxford University Press, 2008.

De Blois, L. (ed.). Administration, Prosopography and Appointment Policies in the Roman Empire: Proceedings of the First Workshop of the International Network, Impact of Empire. Amsterdam: J.C. Gieben, 2001.

Booth, J. \& R. Maltby (eds.). What's in a Name?: The Significance of Proper Names in Classical Latin Literature. Swansea, Wales, Oakville, CT: Classical Press of Wales, 2006.

Bowman, A. K. Life and Letters on the Roman Frontier: Vindolanda and its People. London: British Museum Press, 1998.

Bradley, G. \& J. Wilson. (eds.). Greek and Roman Colonization : Origins, Ideologies and Interactions. Swansea: Classical Press of Wales, 2006.

Braudhead, W. "Colonization, Land Distribution, and Veteran Settlement." In: A Companion to the Roman Army, Erdkamp (ed.). Malden, MA; Oxford: Blackwell, 2007, 148-162.

Breeze, D. "The Organisation of the Legion: The First Cohort and the Equites Legionis." Journal of Roman Studies 59, 1969: 50-55.

Breeze, D. "The Career Structure Below the Centurionate During the Principate." In: Aufstieg und Niedergang der Romischen Welt. Temporini (ed.), Berlin and New York: De Gruyter, 1974, Vol. 2.1, 435-451.

Briquel, D. "La Cittá Murata: Aspetti Religiosi." In: La Cittá Murata in Etruria: Atti del XXV Convegno di Studi Etruschi ed Italici, Chianciano Terme, Sarteano, Chiusi, 30 marzo - 
3 aprile 2005: in memoria di Massimo Pallottino. Atti di convegni / Istituto nazionale di studi etruschi ed italici; 25. Pisa/Roma: Fabrizio Serra Editore, 2008, 121-133.

Brodersen, K. Terra cognita: Studien zur römischen Raumerfassung. Hildesheim; New York: G. Olms, 1995.

Brunt, P. A. "Free Labour and Public Works at Rome." The Journal of Roman Studies, 70 (1980) 81-100.

Buchner, E. Die Sonnenuhr des Augustus. Mainz: von Zabern, 1982.

Buchner, E. "Neues zur Sonnenuhr des Augustus." In: Nurnberger Blatter zur Archaologie 10:1993-1994, 77-84.

Campbell, J. B. "Teach Yourself How to be a General." The Journal of Roman Studies 77 (1987) 13-29.

Campbell, J. B. The Roman Army, 31 BC-AD 337: A Sourcebook. London, New York: Routledge, 1994.

Campbell, J. B. "Shaping the Rural Environment: Surveyors in Ancient Rome." The Journal of Roman Studies 86 (1996) 74-99.

Campbell, J. B. "The Writings of the Roman Land Surveyors: Introduction, Text, Translation and Commentary." Journal of Roman Studies Monograph; No. 9. London : Society for the Promotion of Roman Studies, 2000.

Chouquer, G. L'Arpentage Romain : Histoire des Textes, Droit, Techniques. Paris : France, 2001.

Clarke, K. Between Geography and History: Hellenistic Constructions of the Roman World. Oxford: Oxford University Press, 1999.

Clarysse, W. \& K. Vandorpe. "Information Technologies: Writing, Book Production, and the Role of Literacy." In: Oxford Handbook of Engineering and Technology in the Classical World. Oleson (ed.). Oxford: Oxford University Press, (2008) 715-739.

Classen, C. J. "On the Training of the Agrimensores in Republican Rome and Related Problems: Some Preliminary Observations." Illinois Classical Studies 14 (1994) 16170.

Conte, G. B. Latin Literature: A History. Translated from the Italian by J. B. Solodow and revised by D. Fowler and G. Most. Baltimore: Johns Hopkins University Press, 1999.

Crawford, M. "States Waiting in the Wings: Population Distribution and the End of the Roman Republic." In: People, Land, and Politics: Demographic Developments and the Transformation of Roman Italy 300 BC-AD 14. De Ligt and Northwood (eds.). Leiden; Boston: Brill, 2008, 630-643.

Crawford, M. \& J. D. Cloud (eds.) Roman Statutes. London: Institute of Classical Studies, School of Advanced Study, University of London, 1996.

Cuomo, S. "Divide and Conquer: Frontinus and Roman Land Surveying." Studies in the History and Philosophy of Science 31, (2000) 189-202.

Cuomo, S. Technology and Culture in Greek and Roman Antiquity. Cambridge: Cambridge University Press, 2007.

Davies, G. Roman Siege Works. Stroud: Tempus, 2006. 
Davies, G. "Roman Warfare and Fortification." In: Oxford Handbook of Engineering and Technology in the Classical World. Oleson (ed.). Oxford: Oxford University Press, 2008, 691-711.

Dilke, O. A. W. The Roman Land Surveyors: an Introduction to the Agrimensores. Newton Abbot: David and Charles, 1971.

Dilke, O. A. W. Greek and Roman Maps. Ithaca, N.Y: Cornell University Press, 1985.

Dobson, M. The Army of the Roman Republic: The Second Century BC, Polybius and the Camps at Numantia, Spain. Oxford: Oxbow Books, 2008.

Drum, M. "Cicero's Tenth and Eleventh Philippics: The Republican Advance in the East." In: Cicero's Philippics: History, Rhetoric, and Ideology. Stevenson and Wilson (eds.). Auckland, N.Z.: Polygraphia on behalf of the Prudentia Editorial Board, Dept. of Classics and Ancient History, University of Auckland, 2008, 82-94.

Drummond, A. "Rullus and the Sullan Possessors.” Klio 82: (2000) 126-153.

Edlund-Berry, I. E. M. "Ritual Space and Boundaries in Etruscan Religion." In: The Religion of the Etruscans, de Grummond and Simon (eds.). Austin: University of Texas Press, 2006, 116-131.

Elliott, T. Epigraphic Evidence for Boundary Disputes in the Roman Empire. Unpublished Ph. D. Dissertation. Chapel Hill; North Carolina: University of North Carolina at Chapel Hill, 2004.

Erdkamp, P. The Grain Market in the Roman Empire: a Social, Political and Economic Study. Cambridge: Cambridge University Press, 2005.

Erdkamp, P. (ed.) A Companion to the Roman Army. Malden, MA; Oxford: Blackwell, 2007.

Evans, R. "Phantoms in the Philippics: Catiline, Clodius and Antonian Parallels." In: Cicero's Philippics : History, Rhetoric, and Ideology. Stevenson and Willson (eds.). Auckland, N.Z.: Polygraphia on behalf of the Prudentia Editorial Board, Dept. of Classics and Ancient History, University of Auckland, 2008, 62-81.

Fantham, E. "Caesar as an Intellectual." In: A Companion to Julius Caesar. Griffin (ed.). Chichester, U.K.; Malden, MA: Wiley-Blackwell, (2009) 141-158.

Feeney, D. C. The Gods in Epic: Poets and Critics of the Classical Tradition. Oxford: Clarendon Press, 1991.

Feeney, D. C. Caesar's Calendar: Ancient Time and the Beginnings of History. Berkeley: University of California Press, 2007.

Fink, R. O. Roman Military Records on Papyrus. Cleveland: Case Western Reserve University Press, 1971.

Francese, C. Ancient Rome in So Many Words. New York: Hippocrene Books, 2007.

Frere, S. "Hyginus and the First Cohort." Britannia 11 (1980) 51-60.

Frier, B. W. The Rise of the Roman Jurists: Studies in Cicero's Pro Caecina. Princeton: Princeton University Press, 1985.

Froschauer, H. (ed.) Zeichnungen und Malereien aus den Papyrussammlungen in Berlin und Wien. Papyrussammlung der Österreichischen Nationalbibliothek (Papyrus Erzherzog Rainer). Berlin; New York: Walter de Gruyter, 2009. 
Gargola, D. Lands, Laws, and Gods. Magistrates and Ceremony in the Regulation of Public Lands in Republican Rome. Chapel Hill and London: University of North Carolina Press, 1995.

Geus, K. "Measuring the Earth and the Oikoumene: Zones, Meridians, Sphragides, and Some Other Geographical Terms Used by Eratosthenes of Cyrene." In: Space in the Roman World: Its Perception and Presentation. Talbert and Brodersen (eds.), Munster: Lit, 2004, 11-27.

Gilliver, C. "The Augustan Reforms and the Structure of the Imperial Army." In: $A$ Companion to the Roman Army, Erdkamp (ed.). Malden, MA; Oxford: Blackwell, 2007, 183-200.

Green, P. The Poems of Catullus: Text, Translation, and Commentary. Berkeley: University of California Press, 2005.

Grewe, K. "Tunnels and Canals." In: Oxford Handbook of Engineering and Technology in the Classical World. Oleson (ed.). Oxford: Oxford University Press, (2008) 319-336.

Griffin, M. Seneca: A Philosopher in Politics. ( $2^{\text {nd }}$ Ed.) Oxford: Oxford University Press, 1992.

Griffin, M. Nero: The End of a Dynasty. London: Routledge, 2000.

Griffin, M. (ed.). A Companion to Julius Caesar. Chichester, U.K.; Malden, MA: WileyBlackwell, 2009.

De Grummond, N. T. \& Simon, E. (eds.). The Religion of the Etruscans. Austin: University of Texas Press, 2006.

Hanel, N. "Military Camps, Canabae, and Vici." In: A Companion to the Roman Army, Erdkamp (ed.). Malden, MA; Oxford: Blackwell, 2007, 395-416.

Hannah, R. Greek and Roman Calendars: Constructions of Time in the Classical World. London: Duckworth, 2005.

Hannah, R. Time in Antiquity. London: Routledge, 2009.

Harries, J. Cicero and the Jurists: From Citizens' Law to the Lawful State. London: Duckworth, 2006.

Hinard, F. Les proscriptions de la Rome républicaine. Rome: École française de Rome; Paris: Diffusion de Boccard, 1985.

Horsfall, N. The Culture of the Roman Plebs. London: Duckworth, 2003.

Housman, A. E., M. Annaei Lucani Belli civilis libri decem. Oxford: Oxford University Press, 1926.

Humphrey, J. W., J. P. Olison, J. P., \& A. N. Sherwood (eds. \& trans.) Greek and Roman Technology : A Sourcebook. London; New York: Routledge, 2006.

Inwood, B. (ed.) The Cambridge Companion to the Stoics. Cambridge: Cambridge University Press, 2003.

Inwood, B. Reading Seneca: Stoic Philosophy at Rome. Oxford: Clarendon Press, 2005.

Jameson, M. "Private Space and the Greek City." In: The Greek City: from Homer to Alexander. Murray and Price (eds.). Oxford: Clarendon Press, 1990, 171-195. 
Jones, A. "The Stoics and the Astronomical Sciences." In: The Cambridge Companion to the Stoics. Inwood (ed.). Cambridge: Cambridge University Press, 2003, 328-342

Keaveney, A. The Army in the Roman Revolution. London; New York: Routledge, 2007.

Keay, S. J. \& N. Terrenato. (eds.). Italy and the West: Comparative Issues in Romanization. Oxford: Oxbow Books, 2001.

Kennedy, B. H. The Revised Latin Primer. London: Longman Green and Co., 1941.

Keppie, L. Colonisation and Veteran Settlement in Italy: 47-14 B.C. London: British School at Rome, 1983.

Knox, P. E. (ed.) A Companion to Ovid. Malden: Wiley-Blackwell, 2009.

Konrad, C. F. Plutarch's Sertorius: A Historical Commentary. Chapel Hill: University of North Carolina Press, 1994.

Lancaster, L. "Roman Engineering and Construction." In: Oxford Handbook of Engineering and Technology in the Classical World. Oleson (ed.). Oxford: Oxford University Press, (2008) 256-285.

Lehoux, D. R. Astronomy, Weather, and Calendars in the Ancient World: Parapegmata and Related Texts in Classical and Near-Eastern Societies. Cambridge: Cambridge University Press, 2007.

Lenoir, M. Pseudo-Hyginus Des fortifications du camp. Texte établi, traduit et commenté par Maurice Lenoir. Paris: Les Belles Lettres, 1979.

Leone, A., Palombi, D., and Walker, S. (eds.) Lexicon topographicum urbis Romae : Supplementum IV:Res bene gestae : ricerche di storia urbana su Roma antica in onore di Eva Margareta Steinby. Rome: Quasar, 2007.

Levick, B. "Caesar's Political and Military Legacy to the Roman Emperors." In: $A$ Companion to Julius Caesar. Griffin (ed.). Chichester, U.K.; Malden, MA: WileyBlackwell, 2009, 209-223.

Lewis, M. J. T. Surveying Instruments of Greece and Rome. Cambridge: Cambridge University Press, 2001.

De Ligt, L. \& S. Northwood. (eds.). People, Land, and Politics: Demographic Developments and the Transformation of Roman Italy 300 BC-AD 14. Leiden; Boston: Brill, 2008.

Linderski, J. "The Augural Law." In: Aufstieg und Niedergang der Romischen Welt. H. Temporini (ed.), Berlin and New York: De Gruyter, 1986, Vol. 2, 16.3, 2146-2312.

Lintott, A. Cicero as Evidence: A Historian's Companion. Oxford; New York: Oxford University Press, 2008.

Lovano, M. The Age of Cinna: Crucible of Late Republican Rome. Stuttgart: Franz Steiner Verlag, 2002.

MacMullen, R. Roman Social Relations, 50 B.C. to A.D. 284. New Haven: Yale University Press, 1974.

Maguire, M. The Labours of Herakles. Christchurch: PaperGraphica, 2008.

Malay, H. \& Y. Gul. "Four Smyrnian Inscriptions." Zeitschrift fur Papyrologie und Epigraphik 50 (1983) 283-284. 
Maor, A. The Poison King: The Life and Legend of Mithradates, Rome's Deadliest Enemy. Princeton: Princeton University Press, 2010.

Masterson, M. "Statius' Thebaid and the Realization of Roman Manhood." Phoenix 59.3/4 (2005) 288-315.

Meneghini,R. "La cartografia antica e il catasto di Roma imperial." In: Lexicon Topographicum Urbis Romae : Supplementum IV. Leone, Palombi, and Walker (Eds.). Rome: Quasar, 2007, 205-218.

Moatti, C. Archives et Partage de la Terre dans le Monde Romain: (IIe Siècle avant-Ier Siècle après J.-C.). Rome: École Française de Rome, Palais Farnèse, 1993.

Morselli, C. "Forum Iulium." In: Lexicon topographicum urbis Romae, Vol. 2. Steinby (ed.). Rome: Quasar, (1993) 299-316.

Mouritsen, H. "The Gracchi, the Latins, and the Italian Allies." In: People, Land, and Politics: Demographic Developments and the Transformation of Roman Italy 300 BC-AD 14. De Ligt and Northwood (eds.). Leiden; Boston: Brill, 2008, 471-483.

Munzi, M. "Strategies and Forms of Political Romanization in Central-Southern Etruria (Third Century BC)." In: Italy and the West: Comparative Issues in Romanization. Keay \& Terrenato (eds.). Oxford: Oxbow Books, 2001: 39-53.

Murray, O. \& S. R. F. Price. (eds.) The Greek City: from Homer to Alexander. Oxford: Clarendon Press; New York: Oxford University Press, 1990.

Nicolet, C. "Les finitores ex equestri loco de la Loi Servilia de 63 av. J. C." Latomus 29: 1970: 72-103.

Nicolet, C. Space, Geography, and Politics in the Early Roman Empire. Translation of: L'Inventaire du Monde. The Jerome lectures 19. Ann Arbor: University of Michigan Press, 1991.

Oleson, J. P. (ed.). Oxford Handbook of Engineering and Technology in the Classical World. Oxford: Oxford University Press, 2008.

Parkin, T. G. \& A. Pomeroy. Roman Social History: A Sourcebook. London; New York: Routledge, 2007.

Pelgrom, J. "Settlement Organization and Land Distribution in Latin Colonies before the Second Punic War." In: People, Land, and Politics: Demographic Developments and the Transformation of Roman Italy 300 BC-AD 14. De Ligt and Northwood (eds.). Leiden; Boston: Brill, 2008, 333-372.

Quilici, L. "Land Transport Part 1: Roads and Bridges." In: Oxford Handbook of Engineering and Technology in the Classical World. Oleson (ed.), Oxford: Oxford University Press, (2008) 551-579.

Rawlings, L. "Army and Battle During the Conquest of Italy 350-264 BC.” In: A Companion to the Roman Army. Erdkamp (ed.), Malden, MA; Oxford: Blackwell, 2007, 45-62.

Rich, J. "Lex Licinia, Lex Sempronia: D. G. Niebuhr and the Limitations of Landholding in the Roman Republic." In: People, Land, and Politics: Demographic Developments and the Transformation of Roman Italy 300 BC-AD 14. De Ligt and Northwood (eds.). Leiden; Boston: Brill, 2008, 519-572. 
Richardson, A. Theoretical Aspects of Roman Camp and Fort Design. BAR International Series 1321. Oxford, England: John and Erica Hedges Ltd.; Distributed by Hadrian Books, 2004.

Richlin, A. Marcus Aurelius in Love. Chicago: University of Chicago Press, 2006.

Romm, J. S. The Edges of the Earth in Ancient Thought: Geography, Exploration, and Fiction. Princeton: Princeton University Press, 1992.

Ruiz de Arbulo, J. "Scipionum Opus and Something More: An Iberian Reading of the Provincial Capital (2nd-1st c. BC)." In: Early Roman Towns in Hispania Tarraconensis. Journal of Roman Archaeology. Supplementary series, No. 62. Abad, Casal, Keay, and Ramallo (eds.). Portsmouth, RI (2006) 32-43.

Saddington, D. B. "Early Imperial praefecti castrorum." Historia: Zeitschrift für Alte Geschichte, 45.2 (1996) 244-252.

Salvatore, J. P. "Roman Republican Castrametation: A Reappraisal of Historical and Archaeological Sources." BAR International Series 630. Oxford: Tempus Reparatum, 1996.

Salway, B. "What's in a Name? A Survey of Roman Onomastic Practice from c. 700 B.C. to A.D. 700." The Journal of Roman Studies, 84 (1994) 124-145.

Santangelo, F. Sulla, the Elites and the Empire: A Study of Roman Policies in Italy and the Greek East. Leiden, Boston: Brill, 2007.

Saunders, T. Bucolic Ecology: Virgil's Eclogues and the Environmental Literary Tradition. London: Duckworth, 2008.

Schaldach, K. Romische Sonnenuhren: Eine Einfuhrung in die antike Gnomonik. Frankfurt an Main: Verlag Harri Deutsch, 1998.

Sherk, R. K. Roman Documents from the Greek East; Senatus Consulta and Epistulae to the Age of Augustus. Baltimore: Johns Hopkins University Press, 1969.

Sherk, R. K. "Roman Geographical Exploration and Military Maps." In: Aufstieg und Niedergang der Romischen Welt. H. Temporini (ed.), Berlin and New York: De Gruyter, 1974, Vol. 2, 1, 534-562.

Slater, N.W. "Plautine Negotiations: the Poenulus Prologue Unpacked." Yale Classical Studies 29: 1992, 131-146.

Southern, P. "The Numeri of the Roman Imperial Army.” Britannia.19: (1989), 81-117.

De Souza, P. Piracy in the Graeco-Roman World. Cambridge: Cambridge University Press, 1999.

De Souza, P. "Greek Warfare and Fortification." In: Oxford Handbook of Engineering and Technology in the Classical World. Oleson (ed.). Oxford: Oxford University Press, 2008: 673-690.

Speidel, M. A. "The Captor of Decebalus.” The Journal of Roman Studies 60 (1970) 142-153.

Speidel, M. A. "Specialisation and Promotion in the Roman Imperial Army." In: Administration, Prosopography and Appointment Policies in the Roman Empire: Proceedings of the First Workshop of the International Network, Impact of Empire. De Blois (ed.). Amsterdam: J.C. Gieben, 2001: 53-60.

Steinby, E. M. (ed.) Lexicon Topographicum Urbis Romae. Rome: Quasar, 1993-2000. 
Stevenson, T. \& M. Wilson, M. (eds.). Cicero's Philippics: History, Rhetoric and Ideology. Auckland, N.Z.: Polygraphia on behalf of the Prudentia Editorial Board, Dept. of Classics and Ancient History, University of Auckland, 2008.

Sumi, G. S. Ceremony and Power: Performing Politics in Rome between Republic and Empire. Ann Arbor : University of Michigan Press, 2005.

Syme, R. “Who was Decidius Saxa?” The Journal of Roman Studies 27 (1937) 127-137.

Talbert, R. J. A. (ed.). Barrington Atlas of the Greek and Roman World. Princeton: Princeton University Press, 2000.

Talbert, R. J. A. "Greek and Roman Mapping: Twenty-First century perspectives." In: Cartography in Antiquity and the Middle Ages: Fresh Perspectives New Methods. Talbert and Unger (eds.), Boston: Brill, 2008, 9-28.

Talbert, R. J. A. \& Brodersen, K. (eds.). Space in the Roman World: Its Perception and Presentation. Münster: Lit, 2004.

Talbert, R. J. A. \& Unger, R. W. (eds.) Cartography in Antiquity and the Middle Ages: Fresh Perspectives, New Methods. Leiden; Boston: Brill, 2008.

Thomas, C. "Claudius and the Roman Army Reforms." Historia: Zeitschrift für Alte Geschichte, 53.4 (2004) 424-452.

Thomas, R. F. “Ovid's Reception of Virgil.” In: A Companion to Ovid. Knox (ed.). Malden: Wiley-Blackwell, 2009: 294-307.

Trimble, J. "Process and Transformation on the Severan Marble Plan of Rome." In: Cartography in Antiquity and the Middle Ages: Fresh perspectives New Methods. Talbert and Unger (Eds.), Boston: Brill, 2008, 67-98.

Ulrich, R. B. "Julius Caesar and the Creation of the Forum Iulium." American Journal of Archaeology 97.1 (1993) 49-80.

Uría, J. "Personal Names and Invective in Cicero." In: What's in a Name? The Significance of Proper Names in Classical Latin Literature. Booth and Maltby (eds.). Swansea, Wales, Oakville, CT: Classical Press of Wales, 2006, 13-32.

Walbank, F. W. A Historical Commentary on Polybius. (3 vols.) Oxford: Clarendon Press, $1957-79$

Wallace-Hadrill, A. Rome's Cultural Revolution. Cambridge: Cambridge University Press, 2008.

Weber, M. Roman Agrarian History in its Relation to Roman Public \& Civil Law. Translated from the German edition of 1895 by Richard I. Frank. Claremont: Regina Books, 2008.

Welch, K. "Nimium Felix: Caesar's Felicitas and Cicero's Philippics." In: Cicero's Philippics: History, Rhetoric, and Ideology. Stevenson and Wilson (Eds.). Auckland, N.Z.: Polygraphia on behalf of the Prudentia Editorial Board, Dept. of Classics and Ancient History, University of Auckland, 2008, 181-213.

Welfare, H. \& Swan, V. Roman Camps in England: The Field Archaeology. London: HMSO, 1995. 
White, M. J. "Stoic Natural Philosophy: Physics and Cosmology." In: The Cambridge Companion to the Stoics. Inwood (ed.), Cambridge: Cambridge University Press, 2003, 150 .

Whitehead, D. \& Blyth, P. H. Athenaeus Mechanicus: On Machines. Stuttgart: Steiner, 2004.

Wik, C. M. Annaeus Lucanus. Bellum Civile, Liber IX. (2 vols.) Munich: Saur, 2004.

Wilson, A. I. "Machines in Greek and Roman Technology." In: Oxford Handbook of Engineering and Technology in the Classical World. Oleson (ed.). Oxford: Oxford University Press, 2008: 337-368.

Wiseman, T. P. "Campus Martius." In: Lexicon Topographicum Urbis Romae, Vol. 1. Steinby (ed.). Rome: Quasar, (1993) 220-227.

Woolf, G. Becoming Roman: The Origins of Provincial Civilization in Gaul. Cambridge: Cambridge University Press, 1998.

Zimmer, G. Römische Berufsdarstellungen. Berlin: Mann, 1982. 